See discussions, stats, and author profiles for this publication at: https://www.researchgate.net/publication/331165917

\title{
PENGANTAR PRAKTIKUM MEKATRONIKA TEKSTIL
}

Book · February 2019

CITATIONS

3 authors, including:

Valentinus Galih Vidia Putra

Politeknik STTT Bandung

55 PUBLICATIONS 89 CITATIONS

SEE PROFILE

Some of the authors of this publication are also working on these related projects:
READS

70

Project Spirit Kementerian Perindustrian RI View project 


\section{9}

\section{PENGANTAR}

PRAKTIKUM

MEKATRONIKA

\section{TEKSTIL}

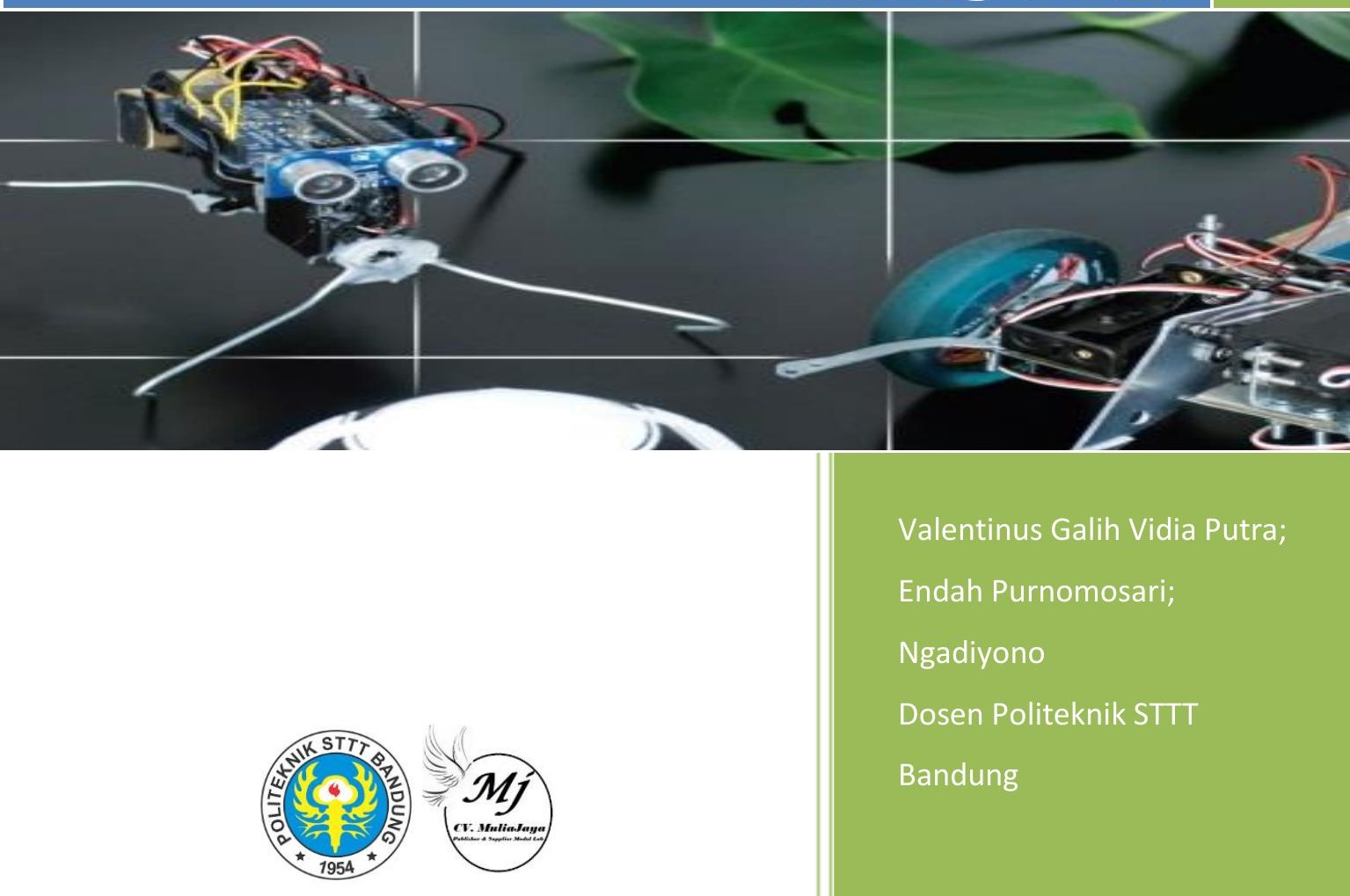




\section{PENGANTAR PRAKTIKUM \\ MEKATRONIKA TEKSTIL}

Penulis:

Dr. Valentinus Galih Vidia Putra, S.Si., M.Sc.

Endah Purnomisari, S.T.

Ngadiyono, S.T.

Editor:

Budi Soewondo, M.Sc.

Terindeks oleh:
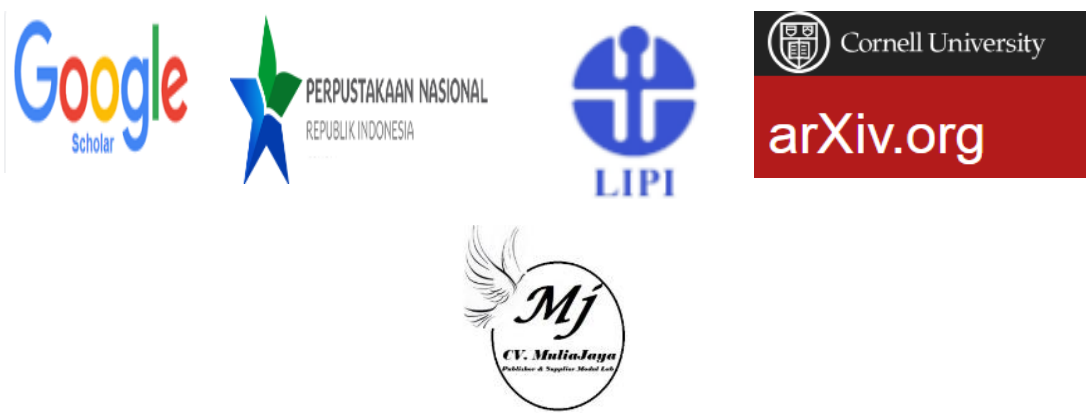
Pengantar Praktikum Mekatronika Tekstil

\section{Penulis}

Dr. Valentinus Galih V.P.M.Sc

Endah Purnomosari, S.T.

Ngadiyono, S.T.

ISBN

: 978-602-51658-3-2

\section{Editor}

Budi Soewondo, M.Sc.

Penyunting

Septian, S.T

Desain Sampul dan Tata Letak

Agustinus Budi, S.S

Penerbit

CV. Mulia Jaya

\section{Redaksi}

Jalan Anggajaya II No. 291-A,

Condong Catur

Kabupaten Sleman, Yogyakarta

Telp: 0812-4994-0973

Email:

cv.muliajaya291@yahoo.com

\section{Cetakan Pertama Januari 2019}

Hak Cipta dilindungi undang-undang

Dilarang memperbanyak karya tulis ini dalam bentuk dan dengan cara Apapun tanpa ijin tertulis dari penerbit dan penulis 


\section{KATA PENGANTAR}

Dengan mempersembahkan puji dan syukur kehadirat Tuhan Yang Maha Esa atas segala rahmat dan karunia-Nya, akhirnya penulis dapat menyelesaikan penyusunan buku yang berjudul "Pengantar Praktikum Mekatronika Tekstil". Buku ini ditulis untuk memberikan suatu pengantar tentang praktikum mekatronika tekstil dan juga terapannya pada dosen atau mahasiswa yang tertarik mempelajari mekatronika tekstil. Penulis menyadari bahwa Buku ini dapat diselesaikan berkat dukungan dan bantuan dari berbagai pihak. Oleh karena itu, ucapan terima kasih kepada semua pihak yang secara langsung dan tidak langsung memberikan kontribusi dalam penyelesaian Buku ini. Pada kesempatan ini penulis juga menghaturkan terima kasih kepada:

\section{Direktur Politeknik STTT Bandung.}

2. Para dosen dan pegawai di lingkungan Politeknik STTT, Bandung.

Buku ini tentunya masih banyak kekurangan dan kelemahan yang penulis tidak sadari. Untuk itu, saran dan masukan untuk perbaikan yang membangun sangat penulis harapkan. Semoga karya kecil ini dapat berguna bagi kita semua.

Bandung, 10 Januari 2019

Penulis 


\section{DAFTAR ISI}

Kata Pengantar

Daftar Isi

Bab 1

Rangkaian Resistor-kapasitor

...Hal.1

Bab 2

tegangan DC

Mikrokontroller Arduino

...Hal. 17

Bab 3

Elektronika Sensor Berbasis

...Hal. 27

Image Processing

Bab 4

Rangkaian dan Instalasi Listrik

...Hal. 36

AC

Bab 5 Rangkaian Instalasi Motor

...Hal. 45

Listrik AC

Bab 6

PLC (Programmable Logic

...Hal. 57

Control)

Bab 7

Elektronika Digital ( Gerbang

...Hal.71

Logika Dasar IC)

Bab 8

Penyearah Gelombang

...Hal. 82

Bab 9

Hukum Kirchoff

...Hal. 92

Biografi Penulis

...Hal. 102 
Dr. Valentinus Galih V.P., S.Si.,M.Sc, Endah Purnomosari, S.T., Ngadiyono, S.T., Politeknik STTT Bandung, Indonesia

\begin{abstract}
Abstrak: Rangkaian RC (Resistor-Kapasitor) adalah suatu rangkaian listrik yang memiliki kombinasi komponen resistor dan kapasitor dimana komponen tersebut biasanya dipasang secara seri atau sejajar. Pengujian ini dilakukan untuk menghitung nilai charged dan discharged pada dua kapasitor dengan kapasitansi yang berbeda dan satu resistor yang sama, selain itu pengujian ini bertujuan untuk membandingkan hasil eksperimen dan teori dengan menggunakan sistem akuisi data. Pengujian secara eksperimen menggunakan arduino uno dan dilakukan pada tegangan maksimum 5 volt.
\end{abstract}

Kata Kunci: Resistor, Kapasitor, Charged, Discharged.

\title{
1.1. Pendahuluan
}

Akuisisi data yaitu suatu prinsip mendapatkan atau mengambil data untuk diproses menjadi suatu informasi yang dikehendaki. Resistor adalah komponen dasar elekronika untuk menghambat arus yang mengalir dalam suatu rangkaian. Kapasitor adalah komponen elektronika untuk menyimpan muatan listrik sementara.

Peristiwa pengisian dan pengosongan muatan kapasitor memegang peranan penting dalam elektronika. Pada posisi pengisian atau charge akan menghasilkan grafik yang naik hinga mencapai suatu kondisi yang stabil. Pada posisi pengisian atau discharge akan menghasilkan grafik menurun. Resistor adalah komponen elektronika pasif yang berfungsi untuk menghambat dan mengatur arus listrik dalam suatu rangkaian elektronika. (Halliday, D., Resnick, R., Walker,1997)

Tujuan Percobaan:

1.1 Menentukan jumlah kapasitansi muatan pada kapasitor.

1.2 Membandingkan kapasitansi muatan padakapasitor secara eksperimen dan teori.

1.3 Mendapatkan hasil $\mathrm{R}^{2}$ pada pengujian charged dan discharged.

\subsection{Dasar Teori}


Kapasitor adalah sebuah benda yang dapat menyimpan muatan listrik. Benda ini terdiri dari dua pelat konduktor yang dipasang berdekatan satu sama lain tapi tidak sampai bersentuhan. Kapasitor dapat menyimpan tenaga listrik dan dapat menyalurkannya kembali (Halliday, D., Resnick, R., Walker, 1997). Kapasitas dari sebuah kapasitor adalah perbandingan antara banyaknya muatan listrik dengan tegangan kapasitor.

$$
C=Q / \Delta V
$$

Menurut Halliday, D., Resnick, R., Walker (1997) besar kapasitansi dirumuskan $C=0,0885 \mathrm{~A} / \mathrm{d}$. Maka kapasitasnya dalam satuan piko farad dengan $A$ adalah luas bidang plat yang saling berhadapan dan saling mempengaruhi dalam satuan $\mathrm{cm}^{2}$ dan $d$ adalah jarak antara plat dalam satuan $\mathrm{cm}$. Bila tegangan antara plat 1 volt dan besarnya muatan listrik pada plat 1 coulomb, maka kemampuan menyimpan listriknya disebut 1 farad. Dalam kenyataannya kapasitor dibuat dengan satuan dibawah 1 farad. Kebanyakan kapasitor elektrolit dibuat mulai dari 1 mikrofarad sampai beberapa milifarad. Resistor adalah salah satu komponen elektronika yang berfungsi sebagai penahan arus yang mengalir dalam suatu rangkaian dan berupa terminal dua komponen elektronik yang menghasilkan tegngan pada terminal yang sebanding dengan arus listrik yang melewatinya sesuai dengan hukun $\mathrm{Ohm}$ $(V=I R)$. (Putra, Ngadiyono, Purnomosari,2016).

Fungsi resistor adalah sebagai pengatur dalam membatasi jumlah arus yang mengalir dalam suatu rangkaian. Dengan adanya resistor menyebabkan arus listrik dapat disalurkan sesuai dengan kebutuhan. Adapun fungsi resistor secara lengkap yaitu :

- Berfungsi untuk menahan sebagian arus listrik agar sesuai dengan kebutuhan suatu rangkaian elektronika.

- Berfungsi untuk menurunkan tegangan sesuai dengan yang dibutuhkan oleh rangkaian elektronika.

- Berfungsi untuk membagi tegangan.

- Berfungsi untuk membangkitkan frekuensi tinggi dan frekuensi rendah dengan bantuan transistor dan kondensator(kapasitor).

Resistor dapat dilihat nilainya dengan melihat warna yang terdapat pada resistor tersebut, adapun warna tersebut dapat dilihat pada Tabel.1.1 dibawah ini. 


\section{Pengantar Praktikum Mekatronika Tekstil}

Tabel.1.1 KodeWarna Resistor (Elektronika Dasar,2017)

\begin{tabular}{|c|c|c|c|c|}
\hline \multicolumn{2}{|c|}{$\begin{array}{l}\text { FIRST DIGIT (pF) } \\
\text { First Colour }\end{array}$} & $\begin{array}{l}\text { SECOND DIGIT (pF) } \\
\text { Second Colour }\end{array}$ & $\begin{array}{l}\text { MULTIPLIER } \\
\text { Third Colow }\end{array}$ & $\begin{array}{l}\text { TOLERANCE } \\
\text { Fouth Colour }\end{array}$ \\
\hline BLACK & 0 & 0 & $\mathrm{x} 1$ & 20 percent \\
\hline BROWN & 1 & 1 & x 10 & \\
\hline RED & 2 & 2 & x 100 & \\
\hline ORANGE & 3 & 3 & $x 1000$ & \\
\hline YELLOW & 4 & 4 & $\mathrm{x} 10,000$ & \\
\hline GREEN & 5 & 5 & $\mathrm{x} 100,000$ & 5 percent \\
\hline BLUE & 6 & 6 & $x 1,000,000$ & \\
\hline VIOLET & 7 & 7 & $\mathrm{x} 10,000,000$ & \\
\hline GREY & 8 & 8 & $\mathrm{x} 100,000,000$ & \\
\hline WHITE & 9 & 9 & x $1,000,000,000$ & 10 percent \\
\hline
\end{tabular}

Rangkaian R-C (PengisianKapasitor) dapat dijelaskan sebagai berikut: Jika suatu kapasitor dalam kondisi tidak bermuatan dan pada waktu awal rangkaian dalam kondisi terbuka, maka saat switch $\mathrm{t}=0$ dalam kondisi tertutup maka kapasitor dalam kondisi dimuati maka besar tegangan antara kedua plat semakin bertambah. Saat muatan maksimum pada kapasitor tercapai, maka besar arusnya adalah nol sedangkan besar tegangannya maksimum, seperti pada Gambar 1.1. (Putra, Ngadiono, \& Purnomosari, 2016)

Besar arus yang terukur pada kondisi rangkaian tertutup adalah sebagai berikut:

$$
V=\frac{Q}{C}=\left(1-e^{-\frac{t}{R C}}\right)
$$
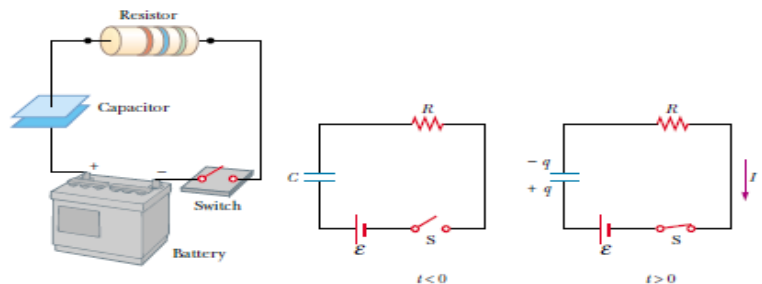

1.1 Rangkaian R-C PengisianKapasitor

(Putra, Ngadiono, \& Purnomosari, 2016)

Rangkaian R-C (Pengosongan kapasitor) dapat dijelaskan sebagai berikut: Jika rangkaian kapasitor bermuatan $Q$ dan resistor tidak dihubungkan dengan sumber tegangan atau dalam kata lain $\varepsilon=0$, sehingga sesaat rangkaian dalam kondisi tertutup, maka akan muncul arus listrik yang muncul dari kapasitor, sedangkan jumlah muatan pada kapasitor akan berkurang. (Putra, Ngadiono, \& Purnomosari, 2016)

dengan besar tegangan adalah : 


$$
V=V_{s} e^{-\frac{t}{R C}}
$$

Susunan rangkaian pada proses discharged dapat dieprlihatkan seperti pada

Gambar 1.2 di bawah
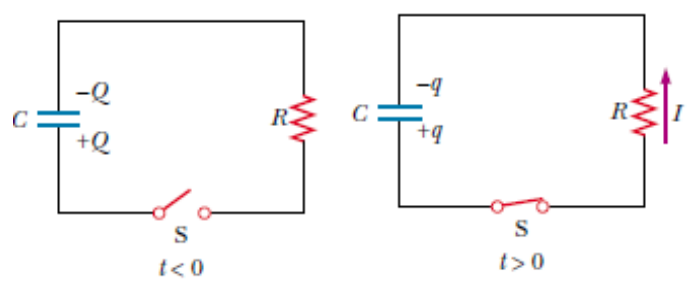

1.2 Rangkaian R-C PengisianKapasitor

(Putra, Ngadiono, \& Purnomosari, 2016)

\subsection{Metode Eksperimen}

Pada metode eksperimen dijelaskan mengenai alat dan bahan, skema percobaan serta prosedur kerja.

Alat dan Bahan

- 1 buah Project Board

- 1 buah Resistor $\left(10 \times 10^{3} \mathrm{ohm}\right)$

- 1 buah Kapasitor $2200 \mu \mathrm{F}$

- 1 buah Kapasitor $330 \mu \mathrm{F}$

- 1 buah Komputer/Laptop

- Kabel Penghubung

- Arduino Uno

- Program Arduino

- Program MATLAB

Skema Percobaan

Skema percobaan dapat diperlihatkan seperti pada Gambar 1.3 dan Gambar 1.4 


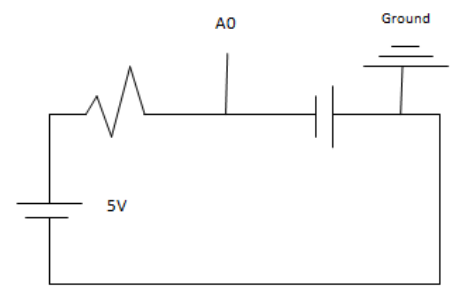

1.3. Skema Rangkaian Pengisian Kapasitor

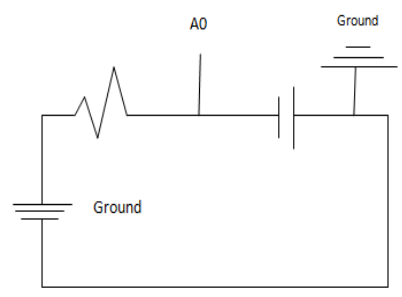

1.4. Skema Rangkaian Pengosongan Kapasitor

Prosedur kerja praktikum dapat dijelaskan sebagai berikut:

1. Program arduino dibuat pada komputer.

2. Resistor dan kapasitor dirangkai pada project board seperti skema di atas.

3. Arduino uno dihubungkan ke komputer.

4. Program dimasukan pada arduino.

5. Kapasitor di isi hingga mencapai tegangan maksimum $5 \mathrm{~V}$ atau sampai nilainya konstan.

6. Kapsitor dikosongkan dari 5V hingga 0 atau nilainya sampai konstan.

7. Perhitungan dilakukan pada Microsoft excel untuk membandingkan hasil eksperimen dan hasil teori.

\subsection{Hasil dan Pembahasan (Sebagai Contoh)}

Pengujian kali ini yaitu pengisian atau charging pada kapasitor $2200 \mu \mathrm{F}$ yang dilakukan dengan menghubungkan resistor pada sumber tegangan $5 \mathrm{~V}$, proses ini disebut sebagai proses pengisian secara eksperimen sehingga menghasilkan tegangan eksperimen pada setiap 2 detik dari tegangan awal 0 volt hingga 5 volt yang kemudian akan dibandingkan dengan hasil prediski teori. Berikut data tegangan eksperimen yang ditunjukan pada Tabel.1.2 
Tabel.1.2 Data Eksperimen pada Pengisian Kapasitor 2200 $\mu \mathrm{F}$

\begin{tabular}{|c|c|c|c|c|c|}
\hline $\begin{array}{c}\text { CHAGER } \\
2200 \\
\end{array}$ & $\mathrm{~T}$ & $\mathrm{~b}$ & $\mathrm{v}$ teori & $(\text { vte-vex })^{\wedge} 2$ & 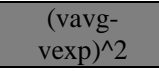 \\
\hline 0 & 0 & 0.045 & .0 .00 & 0 & 18.79555976 \\
\hline 0.11 & 2 & 0.045 & .430 .34 & 0.102620326 & 17.85387514 \\
\hline 0.5 & 4 & 0.045 & .823 .65 & 0.104748638 & 14.71017514 \\
\hline 0.86 & 6 & 0.045 & 1.183 .10 & 0.104395244 & 12.07829822 \\
\hline 1.19 & 8 & 0.045 & 1.511 .62 & 0.103438376 & 9.893444376 \\
\hline 1.49 & 10 & 0.045 & 1.811 .86 & 0.103593372 & 8.096213607 \\
\hline 1.76 & 12 & 0.045 & 2.086 .26 & 0.106444764 & 6.632605915 \\
\hline 2.01 & 14 & 0.045 & 2.337 .04 & 0.106955812 & 5.407413608 \\
\hline 2.25 & 16 & 0.045 & 2.566 .24 & 0.100006928 & 4.348828992 \\
\hline 2.46 & 18 & 0.045 & 2.775 .71 & 0.099672595 & 3.517067454 \\
\hline 2.65 & 20 & 0.045 & 2.967 .15 & 0.100585202 & 2.8405213 \\
\hline 2.83 & 22 & 0.045 & 3.142 .12 & 0.097416738 & 2.266182839 \\
\hline 3 & 24 & 0.045 & 3.302 .02 & 0.091217513 & 1.78325207 \\
\hline 3.15 & 26 & 0.045 & 3.448 .17 & 0.088902542 & 1.405136685 \\
\hline 3.29 & 28 & 0.045 & 3.581 .73 & 0.085106316 & 1.092828993 \\
\hline 3.43 & 30 & 0.045 & 3.703 .80 & 0.074965726 & 0.819721301 \\
\hline 3.54 & 32 & 0.045 & 3.815 .36 & 0.075823794 & 0.632636686 \\
\hline 3.66 & 34 & 0.045 & 3.917 .32 & 0.066214438 & 0.456144378 \\
\hline 3.75 & 36 & 0.045 & 4.010 .51 & 0.067863639 & 0.342675147 \\
\hline 3.85 & 38 & 0.045 & 4.095 .67 & 0.060354258 & 0.235598224 \\
\hline 3.93 & 40 & 0.045 & 4.173 .51 & 0.059294957 & 0.164336686 \\
\hline 4.01 & 42 & 0.045 & 4.244 .64 & 0.055056378 & 0.105875148 \\
\hline 4.09 & 44 & 0.045 & 4.309 .65 & 0.048247798 & 0.060213609 \\
\hline 4.15 & 46 & 0.045 & 4.369 .07 & 0.047992143 & 0.034367455 \\
\hline 4.22 & 48 & 0.045 & 4.423 .37 & 0.041361144 & 0.013313609 \\
\hline 4.27 & 50 & 0.045 & 4.473 .00 & 0.041210574 & 0.004275148 \\
\hline 4.33 & 52 & 0.045 & 4.518 .36 & 0.035480171 & $2.89941 \mathrm{E}-05$ \\
\hline 4.37 & 54 & 0.045 & 4.559 .82 & 0.036030052 & 0.001198225 \\
\hline 4.42 & 56 & 0.045 & 4.597 .70 & 0.031577989 & 0.007159763 \\
\hline 4.47 & 58 & 0.045 & 4.632 .33 & 0.026350146 & 0.018121302 \\
\hline 4.5 & 60 & 0.045 & 4.663 .97 & 0.02688696 & 0.027098225 \\
\hline 4.54 & 62 & 0.045 & 4.692 .89 & 0.023376554 & 0.041867456 \\
\hline 4.57 & 64 & 0.045 & 4.719 .33 & 0.02229831 & 0.055044379 \\
\hline 4.6 & 66 & 0.045 & 4.743 .48 & 0.0205875 & 0.070021302 \\
\hline 4.63 & 68 & 0.045 & 4.765 .56 & 0.018376927 & 0.086798225 \\
\hline
\end{tabular}


7. Pengantar Praktikum Mekatronika Tekstil

\begin{tabular}{|c|c|c|c|c|c|}
\hline 4.66 & 70 & 0.045 & 4.785 .74 & 0.015810388 & 0.105375148 \\
\hline 4.68 & 72 & 0.045 & 4.804 .18 & 0.015420803 & 0.118759764 \\
\hline 4.71 & 74 & 0.045 & 4.821 .03 & 0.012328655 & 0.140336687 \\
\hline 4.73 & 76 & 0.045 & 4.836 .44 & 0.011329011 & 0.155721302 \\
\hline 4.75 & 78 & 0.045 & 4.850 .52 & 0.010103351 & 0.171905917 \\
\hline 4.77 & 80 & 0.045 & 4.863 .38 & 0.008720084 & 0.188890533 \\
\hline 4.78 & 82 & 0.045 & 4.875 .14 & 0.009051618 & 0.197682841 \\
\hline 4.8 & 84 & 0.045 & 4.885 .89 & 0.007376498 & 0.215867456 \\
\hline 4.81 & 86 & 0.045 & 4.895 .71 & 0.007345887 & 0.225259764 \\
\hline 4.82 & 88 & 0.045 & 4.904 .68 & 0.007171452 & 0.234852071 \\
\hline 4.83 & 90 & 0.045 & 4.912 .89 & 0.006870442 & 0.244644379 \\
\hline 4.85 & 92 & 0.045 & 4.920 .39 & 0.004954153 & 0.264828994 \\
\hline 4.85 & 94 & 0.045 & 4.927 .24 & 0.005965716 & 0.264828994 \\
\hline 4.86 & 96 & 0.045 & 4.933 .50 & 0.005402336 & 0.275221302 \\
\hline 4.87 & 98 & 0.045 & 4.939 .22 & 0.004791977 & 0.28581361 \\
\hline 4.88 & 100 & 0.045 & 4.944 .46 & 0.004154449 & 0.296605918 \\
\hline 4.89 & 102 & 0.045 & 4.949 .24 & 0.003508869 & 0.307598225 \\
\hline 4.9 & 104 & 0.045 & 4.953 .60 & 0.002873489 & 0.318790533 \\
\hline 4.91 & 106 & 0.045 & 4.957 .60 & 0.002265579 & 0.330182841 \\
\hline 4.91 & 108 & 0.045 & 4.961 .25 & 0.002626315 & 0.330182841 \\
\hline 4.92 & 110 & 0.045 & 4.964 .58 & 0.00198764 & 0.341775148 \\
\hline 4.92 & 112 & 0.045 & 4.967 .63 & 0.002268737 & 0.341775148 \\
\hline 4.93 & 114 & 0.045 & 4.970 .42 & 0.00163355 & 0.353567456 \\
\hline 4.94 & 116 & 0.045 & 4.972 .96 & 0.001086583 & 0.365559764 \\
\hline 4.94 & 118 & 0.045 & 4.975 .29 & 0.00124541 & 0.365559764 \\
\hline 4.94 & 120 & 0.045 & 4.977 .42 & 0.001400039 & 0.365559764 \\
\hline 4.95 & 122 & 0.045 & 4.979 .36 & 0.000862055 & 0.377752071 \\
\hline 4.95 & 124 & 0.045 & 4.981 .14 & 0.000969524 & 0.377752071 \\
\hline 4.95 & 126 & 0.045 & 4.982 .76 & 0.001073262 & 0.377752071 \\
\hline 4.96 & 128 & 0.045 & 4.984 .24 & 0.000587793 & 0.390144379 \\
\hline 4.96 & 130 & 0.045 & 4.985 .60 & 0.000655386 & 0.390144379 \\
\hline 4.96 & 132 & 0.045 & 4.986 .84 & 0.000720378 & 0.390144379 \\
\hline 4.96 & 134 & 0.045 & 4.987 .97 & 0.000782462 & 0.390144379 \\
\hline 4.97 & 136 & 0.045 & 4.989 .01 & 0.000361293 & 0.402736687 \\
\hline 4.97 & 138 & 0.045 & 4.989 .95 & 0.000398155 & 0.402736687 \\
\hline 4.97 & 140 & 0.045 & 4.990 .82 & 0.000433409 & 0.402736687 \\
\hline 4.97 & 142 & 0.045 & 4.991 .61 & 0.000466937 & 0.402736687 \\
\hline
\end{tabular}




\begin{tabular}{|c|c|c|c|c|c|}
\hline 4.97 & 144 & 0.045 & 4.992 .33 & 0.000498671 & 0.402736687 \\
\hline 4.97 & 146 & 0.045 & 4.992 .99 & 0.000528587 & 0.402736687 \\
\hline 4.98 & 148 & 0.045 & 4.993 .59 & 0.000184804 & 0.415528995 \\
\hline 4.98 & 150 & 0.045 & 4.994 .15 & 0.000200098 & 0.415528995 \\
\hline 4.98 & 152 & 0.045 & 4.994 .65 & 0.000214607 & 0.415528995 \\
\hline 4.98 & 154 & 0.045 & 4.995 .11 & 0.000228312 & 0.415528995 \\
\hline 4.98 & 156 & 0.045 & 4.995 .53 & 0.000241208 & 0.415528995 \\
\hline 4.98 & 158 & 0.045 & 4.995 .92 & 0.000253304 & 0.415528995 \\
\hline 4.98 & 160 & 0.045 & 4.996 .27 & 0.000264618 & 0.415528995 \\
\hline 4.98 & 162 & 0.045 & 4.996 .59 & 0.000275174 & 0.415528995 \\
\hline 4.99 & 164 & 0.045 & 4.996 .88 & 4.73619E-05 & 0.428521302 \\
\hline 4.99 & 166 & 0.045 & 4.997 .15 & $5.11276 \mathrm{E}-05$ & 0.428521302 \\
\hline 4.98 & 168 & 0.045 & 4.997 .40 & 0.000302608 & 0.415528995 \\
\hline 4.99 & 170 & 0.045 & 4.997 .62 & 5.8061E-05 & 0.428521302 \\
\hline 4.99 & 172 & 0.045 & 4.997 .82 & $6.1225 \mathrm{E}-05$ & 0.428521302 \\
\hline 4.99 & 174 & 0.045 & 4.998 .01 & $6.41901 \mathrm{E}-05$ & 0.428521302 \\
\hline 4.99 & 176 & 0.045 & 4.998 .18 & $6.69613 \mathrm{E}-05$ & 0.428521302 \\
\hline 4.99 & 178 & 0.045 & 4.998 .34 & $6.95452 \mathrm{E}-05$ & 0.428521302 \\
\hline 4.99 & 180 & 0.045 & 4.998 .48 & 7.19495E-05 & 0.428521302 \\
\hline 4.99 & 182 & 0.045 & 4.998 .61 & $7.41826 \mathrm{E}-05$ & 0.428521302 \\
\hline 4.99 & 184 & 0.045 & 4.998 .73 & 7.62533E-05 & 0.428521302 \\
\hline 4.99 & 186 & 0.045 & 4.998 .84 & 7.81707E-05 & 0.428521302 \\
\hline 4.99 & 188 & 0.045 & 4.998 .94 & 7.9944E-05 & 0.428521302 \\
\hline 4.99 & 190 & 0.045 & 4.999 .03 & $8.1582 \mathrm{E}-05$ & 0.428521302 \\
\hline 4.99 & 192 & 0.045 & 4.999 .12 & 8.30935E-05 & 0.428521302 \\
\hline 4.99 & 194 & 0.045 & 4.999 .19 & $8.44871 \mathrm{E}-05$ & 0.428521302 \\
\hline 4.99 & 196 & 0.045 & 4.999 .26 & 8.57709E-05 & 0.428521302 \\
\hline 5 & 198 & 0.045 & 4.999 .32 & 4.5584E-07 & 0.44171361 \\
\hline 4.99 & 200 & 0.045 & 4.999 .38 & 8.80398E-05 & 0.428521302 \\
\hline 4.99 & 202 & 0.045 & 4.999 .44 & 8.90392E-05 & 0.428521302 \\
\hline 5 & 204 & 0.045 & 4.999 .48 & $2.6564 \mathrm{E}-07$ & 0.44171361 \\
\hline 5 & 206 & 0.045 & 4.999 .53 & $2.21881 \mathrm{E}-07$ & 0.44171361 \\
\hline Rata-rata & & & & Jumlah & Jumlah \\
\hline 4.335384615 & & & & 2.443961424 & 138.5935846 \\
\hline
\end{tabular}




\section{Pengantar Praktikum Mekatronika Tekstil}

Untuk menentukan nilai tegangan secara teori maka dapat menggunakan persamaan dibawah ini :

$$
b=\frac{1}{R C}
$$

Persamaan tersebut berasal dari rumus charging untuk proses pengisian,yaitu :

$$
V_{c}=\varepsilon\left(1-e^{-t b}\right)
$$

Pada eksperimen ini diketahui nilai resistansi $R$ sebesar $10000 \mathrm{ohm}$ dan kapasitansinya secara teori (literatur) sebesar $2200 \mu \mathrm{F}$ maka nilai $b$ nya sebesar

$$
b=\frac{1}{10000 \times 2200 \times 10^{-6}}=0,045
$$

Kemudian dilihat keakuratan penentuan nilai tegangan eksperimen dengan teori, data diplotkan pada grafik yang ditunjukan pada Gambar 1.5

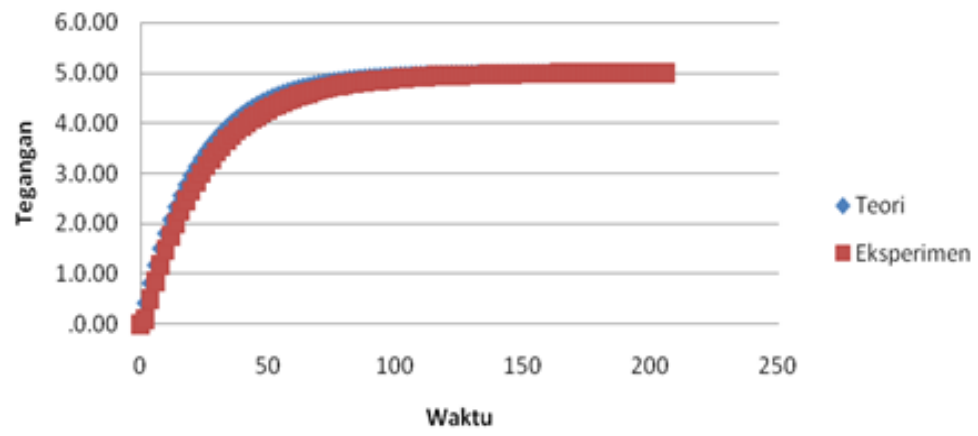

1.5 Kurva tegangan terhadap waktu

Dari kurva tersebut dapat dilihat perbeda anantara tegangan secara eksperimen dan teori sangat sedikit untuk melihat nilai keakuratannya maka dicari $\mathrm{R}^{2}$ dari kurva tersebut dengan menggunakan teorema fitting berikut data hasil perhitungan $\mathrm{R}^{2}$

$$
R^{2}=1-\frac{(\text { vte-vex })^{\wedge} 2}{(\text { vavg }- \text { vexp })^{\wedge} 2}=0.98236
$$

Dapat dilihat dari $\mathrm{R}^{2}$ nya bahwa tegangan secara eksperimen sesuai dengan tegangan secara teori, hal ini menunjukan metode ini dapat digunakan untuk menentukan kapasitansi suatu kapasitor. Berdasarkan nilai R2 diatas dapat dikatakan bahwa antara ekperimen dan teori hasilnya hamper mendekati nilai yang sama. Kemudian dicari nilai kapasitor secara eksperimen melalui persamaan berikut

$$
C=\frac{1}{R b}=2222 \mu F
$$


Semakin besar nilai kapasitor maka akan semakin banyak waktu yang dibutuhkan untuk mengisi kapasitor tersebut sampai mencapai 5 volt. Dan apabila semakin besar nilai kapasitansinya maka akan semakin kecil nilai tegangannya. Dalam pengujian ini dapat dibandingkan antara kapasitor dengan nilai $2200 \mu \mathrm{F}$ dengan kapasitor $330 \mu \mathrm{F}$. Pada Tabel 1.3 dibawah ini adalah hasil akuisi data eksperimen dan teori untuk kapasitor $330 \mu \mathrm{F}$.

Tabel 1.3. Data Pengisian Kapasitor 330 $\mu \mathrm{F}$

\begin{tabular}{|c|c|c|c|c|c|}
\hline $\begin{array}{r}\text { CHAGER } \\
330 \\
\end{array}$ & $\mathrm{~T}$ & B & Vteori & $(\text { vte-vex })^{\wedge} 2$ & $\begin{array}{l}(\text { vavg- } \\
\text { vexp })^{\wedge} 2\end{array}$ \\
\hline 0 & 0 & 0.303 & 0.000 & 0.000 & 16.903 \\
\hline 1.31 & 2 & 0.303 & 2.272 & 0.926 & 7.847 \\
\hline 3 & 4 & 0.303 & 3.512 & 0.262 & 1.235 \\
\hline 3.89 & 6 & 0.303 & 4.188 & 0.089 & 0.049 \\
\hline 4.37 & 8 & 0.303 & 4.557 & 0.035 & 0.067 \\
\hline 4.64 & 10 & 0.303 & 4.758 & 0.014 & 0.279 \\
\hline 4.79 & 12 & 0.303 & 4.868 & 0.006 & 0.461 \\
\hline 4.87 & 14 & 0.303 & 4.928 & 0.003 & 0.576 \\
\hline 4.93 & 16 & 0.303 & 4.961 & 0.001 & 0.670 \\
\hline 4.95 & 18 & 0.303 & 4.979 & 0.001 & 0.703 \\
\hline 4.97 & 20 & 0.303 & 4.988 & 0.000 & 0.737 \\
\hline 4.98 & 22 & 0.303 & 4.994 & 0.000 & 0.755 \\
\hline 4.98 & 24 & 0.303 & 4.997 & 0.000 & 0.755 \\
\hline 4.99 & 26 & 0.303 & 4.998 & 0.000 & 0.772 \\
\hline 5 & 28 & 0.303 & 4.999 & 0.000 & 0.790 \\
\hline Rata-rata & & & & Jumlah & Jumlah \\
\hline 4.111333333 & & & & 1.338 & 31.809 \\
\hline
\end{tabular}

Dari data tersebut dapat dilihat waktu pengisian pada kapsitor $2200 \mu \mathrm{F}$ lebih

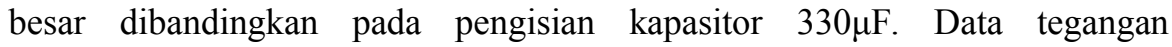
eksperimen dan teori diplotkan kurva hubungan tegangan dan waktu pada Gambar 1.6 dibawah ini. 
11. Pengantar Praktikum Mekatronika Tekstil

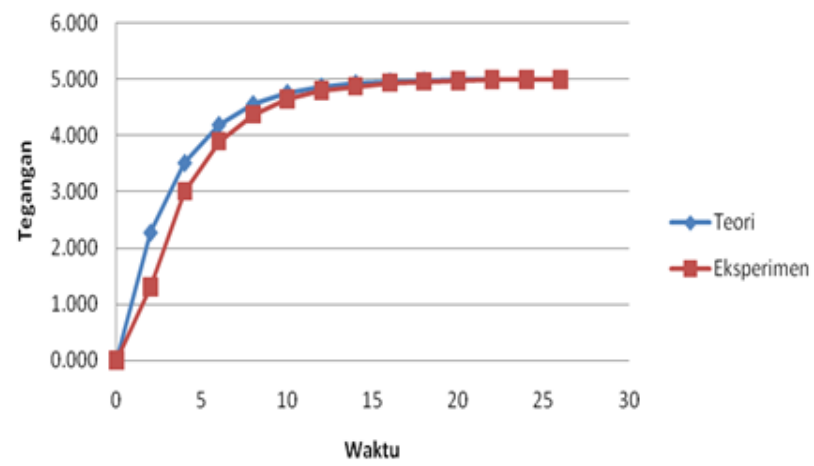

1.6 Proses charged kapasitor $330 \mu \mathrm{F}$

Berdasarkan hasil analisa dua tabel diatas dapat dibandingkan bahwa kurva pengisian untuk kapasitor $2200 \mu \mathrm{F}$ membutuhkan waktu yang lebih lama untuk pengisian 5 volt dibandingan kapasitor $330 \mu \mathrm{F}$. Berdasarkan hasil validasi dapat dieprlihatkan bahwa kurva tersebut menunjukan sedikit perbedaan antara tegangan yang dihasilkan secara eksperimen dan tegangan secara prediksi teori namun perbedaan tersebut tidak terlalu jauh. Seperti yang terlihat pada Tabel.1.4 dibawah ini dapat diperlihatkan tabel pengosongan kapasitor

Tabel 1.4 Data Pengosongan Kapasitor 2200 $\mu \mathrm{F}$

\begin{tabular}{|c|c|c|c|c|c|}
\hline $\begin{array}{c}\text { DISCHARGE } \\
2200\end{array}$ & $\mathrm{~T}$ & $\mathrm{~b}$ & $\mathrm{v}$ teori & $\begin{array}{c}\text { (vavg- } \\
\text { (vexp) } 2\end{array}$ \\
\hline 5 & 0 & 0.045 & 5 & 0 & 17.26966805 \\
\hline 4.91 & 2 & 0.045 & 4.569655926 & 0.115834088 & 16.52974583 \\
\hline 4.52 & 4 & 0.045 & 4.176351057 & 0.118094596 & 13.5106162 \\
\hline 4.16 & 6 & 0.045 & 3.816897472 & 0.117719345 & 10.99372731 \\
\hline 3.83 & 8 & 0.045 & 3.48838163 & 0.11670311 & 8.914279163 \\
\hline 3.54 & 10 & 0.045 & 3.188140758 & 0.123804926 & 7.266685336 \\
\hline 3.26 & 12 & 0.045 & 2.913741262 & 0.119895114 & 5.835505089 \\
\hline 3.01 & 14 & 0.045 & 2.662959005 & 0.120437452 & 4.690165583 \\
\hline 2.77 & 16 & 0.045 & 2.43376128 & 0.113056477 & 3.708239657 \\
\hline 2.56 & 18 & 0.045 & 2.224290331 & 0.112700982 & 2.943554472 \\
\hline 2.36 & 20 & 0.045 & 2.032848299 & 0.107028236 & 2.297282867 \\
\hline 2.17 & 22 & 0.045 & 1.857883455 & 0.097416738 & 1.757424843 \\
\hline 2.01 & 24 & 0.045 & 1.697977628 & 0.09735796 & 1.358807559 \\
\hline 1.85 & 26 & 0.045 & 1.551834706 & 0.088902542 & 1.011390275 \\
\hline
\end{tabular}




\begin{tabular}{|c|c|c|c|c|c|}
\hline 1.71 & 28 & 0.045 & 1.418270132 & 0.085106316 & 0.749400152 \\
\hline 1.58 & 30 & 0.045 & 1.296201303 & 0.0805417 & 0.541223609 \\
\hline 1.46 & 32 & 0.045 & 1.184638793 & 0.075823794 & 0.379060646 \\
\hline 1.34 & 34 & 0.045 & 1.082678337 & 0.066214438 & 0.245697683 \\
\hline 1.24 & 36 & 0.045 & 0.989493495 & 0.062753509 & 0.156561881 \\
\hline 1.15 & 38 & 0.045 & 0.904328963 & 0.060354258 & 0.093439658 \\
\hline 1.06 & 40 & 0.045 & 0.826494441 & 0.054524846 & 0.046517436 \\
\hline 0.98 & 42 & 0.045 & 0.755359044 & 0.050463559 & 0.018408794 \\
\hline 0.91 & 44 & 0.045 & 0.690346187 & 0.048247798 & 0.004313733 \\
\hline 0.84 & 46 & 0.045 & 0.630928909 & 0.043710721 & $1.86709 \mathrm{E}-05$ \\
\hline 0.78 & 48 & 0.045 & 0.576625605 & 0.041361144 & 0.004137189 \\
\hline 0.72 & 50 & 0.045 & 0.526996123 & 0.037250497 & 0.015455708 \\
\hline 0.66 & 52 & 0.045 & 0.481638191 & 0.031812935 & 0.033974227 \\
\hline 0.61 & 54 & 0.045 & 0.440184163 & 0.028837419 & 0.054906325 \\
\hline 0.57 & 56 & 0.045 & 0.402298034 & 0.028123949 & 0.075252004 \\
\hline 0.52 & 58 & 0.045 & 0.367672719 & 0.023203601 & 0.105184103 \\
\hline 0.48 & 60 & 0.045 & 0.336027564 & 0.020728062 & 0.132729782 \\
\hline 0.45 & 62 & 0.045 & 0.30710607 & 0.020418675 & 0.155489042 \\
\hline 0.42 & 64 & 0.045 & 0.280673814 & 0.019411786 & 0.180048301 \\
\hline 0.39 & 66 & 0.045 & 0.256516552 & 0.017817831 & 0.20640756 \\
\hline 0.36 & 68 & 0.045 & 0.234438476 & 0.015765696 & 0.234566819 \\
\hline 0.33 & 70 & 0.045 & 0.214260634 & 0.013395601 & 0.264526079 \\
\hline 0.3 & 72 & 0.045 & 0.195819475 & 0.010853582 & 0.296285338 \\
\hline 0.28 & 74 & 0.045 & 0.178965525 & 0.010207965 & 0.318458177 \\
\hline 0.26 & 76 & 0.045 & 0.163562175 & 0.009300254 & 0.341431017 \\
\hline 0.24 & 78 & 0.045 & 0.149484572 & 0.008193043 & 0.365203857 \\
\hline 0.22 & 80 & 0.045 & 0.136618612 & 0.006952456 & 0.389776696 \\
\hline 0.21 & 82 & 0.045 & 0.12486001 & 0.007248818 & 0.402363116 \\
\hline 0.2 & 84 & 0.045 & 0.114113457 & 0.007376498 & 0.415149536 \\
\hline 0.18 & 86 & 0.045 & 0.104291847 & 0.005731724 & 0.441322375 \\
\hline 0.17 & 88 & 0.045 & 0.095315571 & 0.005577764 & 0.454708795 \\
\hline 0.15 & 90 & 0.045 & 0.087111873 & 0.003954916 & 0.482081634 \\
\hline 0.14 & 92 & 0.045 & 0.079614258 & 0.003646438 & 0.496068054 \\
\hline 0.13 & 94 & 0.045 & 0.072761953 & 0.003276194 & 0.510254474 \\
\hline 0.12 & 96 & 0.045 & 0.066499418 & 0.002862312 & 0.524640894 \\
\hline
\end{tabular}


13. Pengantar Praktikum Mekatronika Tekstil

\begin{tabular}{|c|c|c|c|c|c|}
\hline 0.11 & 98 & 0.045 & 0.060775892 & 0.002423013 & 0.539227313 \\
\hline 0.1 & 100 & 0.045 & 0.055544983 & 0.001976249 & 0.554013733 \\
\hline 0.09 & 102 & 0.045 & 0.050764292 & 0.001539441 & 0.569000153 \\
\hline 0.09 & 104 & 0.045 & 0.046395069 & 0.00190139 & 0.569000153 \\
\hline 0.08 & 106 & 0.045 & 0.042401901 & 0.001413617 & 0.584186573 \\
\hline 0.07 & 108 & 0.045 & 0.038752419 & 0.000976411 & 0.599572992 \\
\hline 0.07 & 110 & 0.045 & 0.035417045 & 0.001195981 & 0.599572992 \\
\hline 0.06 & 112 & 0.045 & 0.032368742 & 0.000763486 & 0.615159412 \\
\hline 0.06 & 114 & 0.045 & 0.029582802 & 0.000925206 & 0.615159412 \\
\hline 0.05 & 116 & 0.045 & 0.027036646 & 0.000527316 & 0.630945832 \\
\hline 0.05 & 118 & 0.045 & 0.024709634 & 0.000639603 & 0.630945832 \\
\hline 0.05 & 120 & 0.045 & 0.022582905 & 0.000751697 & 0.630945832 \\
\hline 0.04 & 122 & 0.045 & 0.020639221 & 0.00037484 & 0.646932252 \\
\hline 0.04 & 124 & 0.045 & 0.018862828 & 0.00044678 & 0.646932252 \\
\hline 0.04 & 126 & 0.045 & 0.017239326 & 0.000518048 & 0.646932252 \\
\hline 0.04 & 128 & 0.045 & 0.015755558 & 0.000587793 & 0.646932252 \\
\hline 0.03 & 130 & 0.045 & 0.014399496 & 0.000243376 & 0.663118671 \\
\hline 0.03 & 132 & 0.045 & 0.013160148 & 0.000283581 & 0.663118671 \\
\hline 0.02 & 134 & 0.045 & 0.01202747 & $6.35612 \mathrm{E}-05$ & 0.679505091 \\
\hline 0.02 & 136 & 0.045 & 0.01099228 & 8.1139E-05 & 0.679505091 \\
\hline 0.02 & 138 & 0.045 & 0.010046187 & $9.90784 \mathrm{E}-05$ & 0.679505091 \\
\hline 0.02 & 140 & 0.045 & 0.009181524 & 0.000117039 & 0.679505091 \\
\hline 0.02 & 142 & 0.045 & 0.008391281 & 0.000134762 & 0.679505091 \\
\hline 0.01 & 144 & 0.045 & 0.007669053 & 5.43331E-06 & 0.696091511 \\
\hline 0.01 & 146 & 0.045 & 0.007008987 & $8.94616 \mathrm{E}-06$ & 0.696091511 \\
\hline 0.01 & 148 & 0.045 & 0.006405732 & $1.29188 \mathrm{E}-05$ & 0.696091511 \\
\hline 0.01 & 150 & 0.045 & 0.005854398 & $1.7186 \mathrm{E}-05$ & 0.696091511 \\
\hline 0.01 & 152 & 0.045 & 0.005350517 & $2.16177 \mathrm{E}-05$ & 0.696091511 \\
\hline 0.01 & 154 & 0.045 & 0.004890004 & 2.61121E-05 & 0.696091511 \\
\hline 0.01 & 156 & 0.045 & 0.004469127 & $3.05906 \mathrm{E}-05$ & 0.696091511 \\
\hline 0.01 & 158 & 0.045 & 0.004084475 & 3.49934E-05 & 0.696091511 \\
\hline 0 & 160 & 0.045 & 0.003732929 & $1.39348 \mathrm{E}-05$ & 0.712877931 \\
\hline \multirow{2}{*}{$\begin{array}{c}\text { Rata-rata } \\
0.844320988\end{array}$} & & & & \multirow{2}{*}{$\begin{array}{c}\text { Jumlah } \\
2.478156807 \\
\end{array}$} & \multirow{2}{*}{$\begin{array}{c}\text { Jumlah } \\
110.6833196 \\
\end{array}$} \\
\hline & & & & & \\
\hline
\end{tabular}


Berikut ini adalah grafik hubungan waktu dan tegangan proses pengosongan kapasitor 2200 $\mu \mathrm{F}$ yang ditunjukkan pada Gambar 1.7

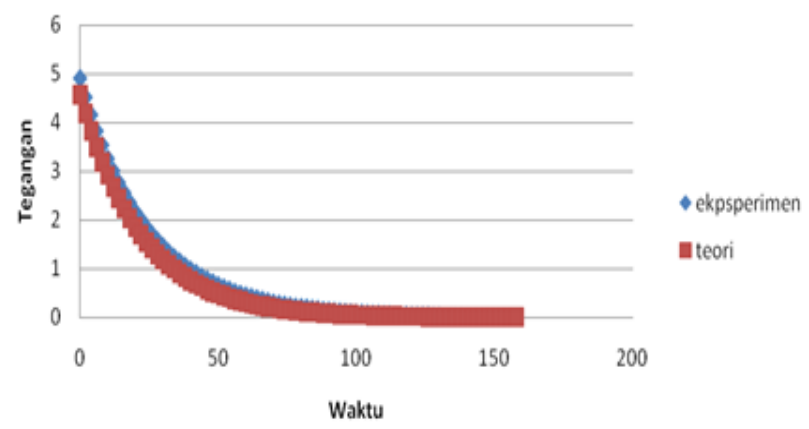

1.7 Kurva Pengosongan Kapasitor $2222 \mu \mathrm{F}$

Dari data tabel diatas didapatkan $\mathrm{R}^{2}$ sebesar 0.977610386, hasil tersebut menunjukan kesesuaian antara tegangan eksperimen dan tegangan teori yang didapat melalui persamaan discharge yang sangat baik. Dan menghasilkan kapasitor $2222 \mu \mathrm{F}$, hal tersebut menunujukan sedikit perbedaan dengan kapasitansi prediksi pada kapasitor $2200 \mu \mathrm{F}$ namun hasil yang diperoleh masih tidak jauh berbeda dengan kapasitor yang sebenarnya. Tabel $\mathbf{1 . 5}$ adalah data pengosongan kapasitor $330 \mu \mathrm{F}$.

Tabel 1.5 data pengosongan kapasitor $330 \mu \mathrm{F}$

\begin{tabular}{|c|c|c|c|c|c|}
\hline $\begin{array}{c}\text { DISCHAGER } \\
330\end{array}$ & $\mathrm{~T}$ & $\mathrm{~B}$ & Vteori & $\begin{array}{c}\text { (vavg- } \\
\text { (vexp) }\end{array}$ \\
\hline 5 & 0 & 0.303 & 5 & 0 & 12.05081632 \\
\hline 2.91 & 2 & 0.303 & 2.727643126 & 0.03325403 & 1.908344897 \\
\hline 1.58 & 4 & 0.303 & 1.488007404 & 0.008462638 & 0.002644898 \\
\hline 0.87 & 6 & 0.303 & 0.811750634 & 0.003392989 & 0.433716327 \\
\hline 0.47 & 8 & 0.303 & 0.442833207 & 0.000738035 & 1.12057347 \\
\hline 0.26 & 10 & 0.303 & 0.241578191 & 0.000339363 & 1.60927347 \\
\hline 0.15 & 12 & 0.303 & 0.131787818 & 0.000331684 & 1.900459185 \\
\hline 0.08 & 14 & 0.303 & 0.071894027 & $6.57068 \mathrm{E}-05$ & 2.098359185 \\
\hline 0.05 & 16 & 0.303 & 0.03922025 & 0.000116203 & 2.186173471 \\
\hline 0.02 & 18 & 0.303 & 0.021395769 & $1.94817 \mathrm{E}-06$ & 2.275787756 \\
\hline 0.01 & 20 & 0.303 & 0.011672004 & $2.7956 \mathrm{E}-06$ & 2.306059185 \\
\hline 0 & 22 & 0.303 & 0.006367413 & $4.05439 \mathrm{E}-05$ & 2.336530614 \\
\hline
\end{tabular}




\begin{tabular}{|c|l|l|l|c|c|}
\hline Rata-rata & & & & Jumlah & Jumlah \\
\hline 0.95 & & & & 0.046745935 & 30.22873878 \\
\hline
\end{tabular}

Dari data tersebut didapatkan nilai $\mathrm{R}^{2}$ sebesar 0.998453593 serta dapat dilihat dari grafik yang tunjukan pada Gambar 1.8 dibawah ini kurva pengosongan kapasitor $330 \mu \mathrm{F}$.

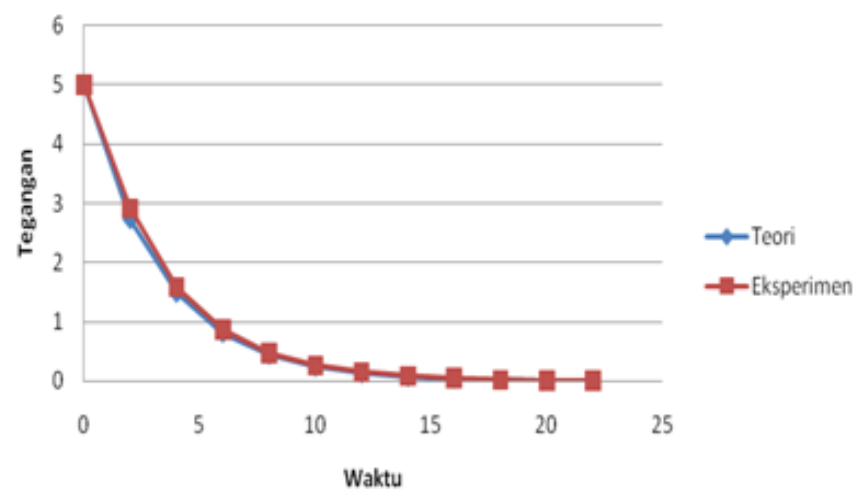

1.8 Kurva pengosongan kapasitor 330 mikrofarad

Dari kurva diatas dapat dilihat kesesuaian hasil antara eksperimen dan teori yang mendekati sama, namun masih terdapat perbedaan yang sangat kecil sehingga masih dapat dikatakan memiliki hasil yang cukup akurat untuk mendapatkan nilai kapasitor sebesar $330 \mu \mathrm{F}$.

\section{Kesimpulan}

Berdasarkan dasar teori serta hasil dan pembahasan praktikum, maka didapatkan:

Telah berhasil ditentukan jumlah kapasitansi muatan pada kapasitor.

Telah berhasil dibandingkan kapasitansi muatan pada kapasitor secara eksperimen dan prediksi teori.

Telah didapatkan hasil $\mathrm{R}^{2}$ pada pengujian charged dan discharged, yaitu sebesar:

$\mathrm{R}^{2}$ pada pengisian kapasitor $330 \mu \mathrm{F}$ yaitu 0.957924351 dan $\mathrm{R}^{2}$ pengosongan $330 \mu \mathrm{F}$ yaitu 0.998453593

$\mathrm{R}^{2}$ pada pengisian kapasitor $2200 \mu \mathrm{F}$ yaitu 0.982365984 dan $\mathrm{R}^{2}$ pengosongan $2200 \mu \mathrm{F}$ yaitu 0.977610386

\section{Referensi}


[1] _. Membaca nilai Kapasitor. Retrieved Mei 20, 2017, from Elektronika Dasar: http://elektronika-dasar.web.id/membaca-nilai-kapasitor/tabel-kode-warna-kapasitor/. 2017

[2] Halliday, D., Resnick, R., Walker, Fundamenthal of Physics-Extended, $5^{\text {th }}$, John Wiley \& Sons, New York, 1997.

[3] Putra, VGV., Ngadiono, \& Purnomosari, E.. Pengantar Listrik Magnet dan Terapannya. Yogyakarta: CV. Mulia Jaya, 2016. 
Dr. Valentinus Galih V.P., S.Si.,M.Sc, Endah Purnomosari, S.T., Ngadiyono, S.T., Politeknik STTT Bandung, Indonesia

\begin{abstract}
Abstrak Pada bab ini akan dijelaskan tentang penggunaan mikrokontroller arduino beserta penggunaan sensor dan aktuator. Beberapa listing program dan contoh aplikasi diterangkan pada bab ini, seperti pada aplikasi sensor dan aktuator sederhana menggunakan Led, sensor sentuh dan sensor cahaya
\end{abstract}

Kata Kunci: Mikrokontroller, aktuator, sensor. .

\title{
2.1. Pendahuluan
}

Penerapan ilmu Fisika dalam berbagai bidang telah banyak ditemui. Halliday, D., Resnick, R., Walker (1997) menyatakan bahwa penerapan ilmu fisika modern dapat dilihat dari berbagai pemanfaatanya di ebrbagai bidang seperti industri makanan, industri pesawat, industri persenjataan, misi luar angkasa dsb. Dalam dunia tekstil sudah mulai banyak penerapan dan penggunaan bidang fisika khususnya alat-alat elektronik dengan berbagai sensor dan aktuator berbasis mikrokontroler yang merupakan terapan dari bagian ilmu dasar dan fundamental fisika. Industri tekstil dalam penggunaannya sudah memakai berbagai sensor dan aktuator untuk mempermudah pengerjaan operator, akademisi serta praktisi dalam mempercepat dan mempermudah suatu proses produksi (Putra, Ngadiyono dan Endah, 2016). Mikrokontroller sebagai alat yang bisa dikatakan kecil, maka dalam penggunaanya bisa diterapkan dalam berbagai hal seperti pakaian, alatalat elektronik, rumah, dan masih banyak lagi. Penerapan mikrokontroler arduino yang memiliki berbagai aplikasi sensor dan aktuator, diharapkan dapat mengembangkan pengetahuan mahasiswa untuk mengetahui cara kerja sensor dan dapat membuat piranti alat sensor yang dibutuhkan pada dunia pertekstilan baik dalam mesin maupun hasil produksinya.

Tujuan Percobaan: 
Membuat program dan rangkaian sensor photocell (LDR) dan sensor touch dengan indikator LED pada board Arduino menyala.

\subsection{Dasar Teori}

Arduino adalah kit elektronik atau papan rangkaian elektronik open source yang di dalamnya terdapat komponen utama yaitu sebuah chip mikrokontroler dengan jenis AVR dari perusahaan Atmel (Putra Adi Angga,2014). Chip atau IC (integrated circuit) dapat diprogram menggunakan komputer. Tujuan menanamkan program pada mikrokontroler adalah agar rangkaian elektronik dapat membaca input, memproses input tersebut dan kemudian menghasilkan output sesuai yang diinginkan. Jadi mikrokontroler bertugas sebagai 'otak' yang mengendalikan input, proses dan output sebuah rangkaian elektronik. (Gambar 2.1)

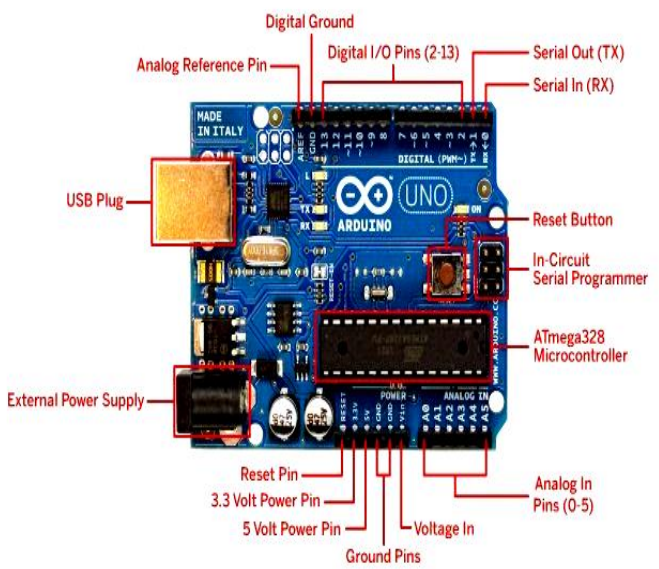

2.1Skema Arduino Uno-R3(Putra Adi Angga,2014)

Beberapa kelebihan menggunakan Arduino :

- Sudah memiliki sarana komunikasi USB, sehingga pengguna Laptop yang tidak memiliki port serial/RS323 bisa menggunakannya.

- Bahasa pemrograman relatif mudah karena software Arduino dilengkapi dengan kumpulan library yang cukup lengkap.

- Memiliki modul siap pakai (shield) yang bisa ditancapkan pada board Arduino. Misalnya shield GPS, Ethernet, SD Card, dll.

Dalam Board Arduino sendiri secara sederhana terdiri dari beberapa bagian, yaitu seperti pada Gambar 2.2 :

- $\quad$ Soket USB 
Soket USB adalah soket untuk kabel USB yang disambungkan ke komputer atau laptop. Berfungsi untuk mengirimkan program ke Arduino dan juga sebagai port komunikasi serial.

- Input / Output Digital

Input/Output Digital atau digital pin adalah pin-pin untuk menghubungkan Arduino dengan komponen atau rangkaian digital. Misalnya kalau ingin membuat LED berkedip, LED tersebut bisa dipasang pada salah satu pin I/O digital dan ground. Komponen lain yang menghasilkan output digital atau menerima input digital bisa disambungkan ke pin-pin ini.

- Input Analog

Input Analog atau analog pin adalah pin-pin yang berfungsi untuk menerima sinyal dari komponen atau rangkaian analog. Misalnya dari potensiometer, sensor suhu, sensor cahaya, dsb.

- Catu Daya

Pin-pin catu daya adalah pin yang memberikan tegangan untuk komponen atau rangkaian yang dihubungkan dengan Arduino. Pada bagian catu daya ini terdapat juga pin Vin dan Reset. Vin digunakan untuk memberikan tegangan langsung kepada Arduino tanpa melalui tegangan USB atau adaptor. Reset adalah pin untuk memberikan sinyal reset melalui tombol atau rangkaian eksternal.

- Baterai / Adaptor

Soket baterai atau adaptor digunakan untuk menyuplai Arduino dengan tegangan dari baterai/adaptor $9 \mathrm{~V}$ pada saat Arduino sedang tidak disambungkan ke komputer. Jika Arduino sedang disambungkan ke komputer melalui USB, Arduino mendapatkan suplai tegangan dari USB, jadi tidak perlu memasang baterai/adaptor saat memprogram Arduino.

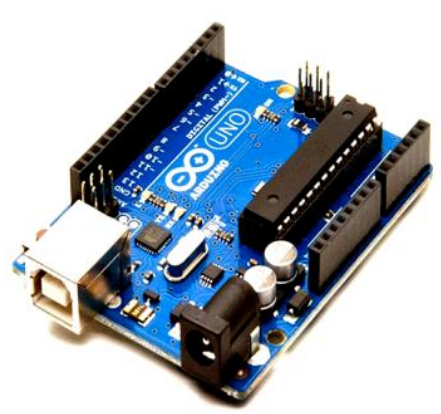

2.2Arduino Uno-R3(Putra Adi Angga,2014) 


\section{Arduino Uno}

Jenis yang ini adalah yang paling banyak digunakan. Terutama untuk pemula sangat disarankan untuk menggunakan Arduino Uno. Dan banyak sekali referensi yang membahas Arduino Uno. Versi yang terakhir adalah Arduino Uno R3 (Revisi 3), menggunakan ATMEGA328 sebagai Mikrokontrolernya, memiliki 14 pin I/O digital dan 6 pin input analog.

Sensor Cahaya dan sensor Touch

Sensor yang digunakan untuk sensor cahaya yaitu jenis LDR (Light Depending Resistor)

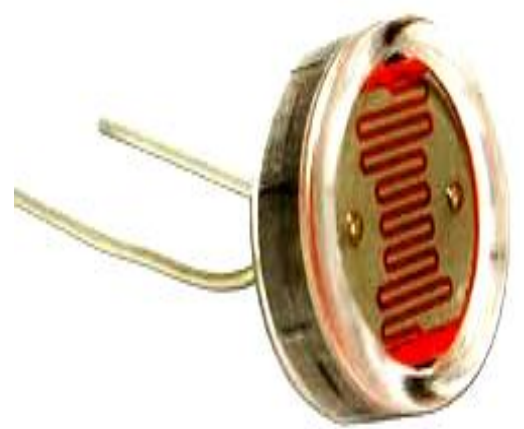

2.3 Light Depending Resistor (Elektro Zona,2017)

LDR adalah sensor cahaya yang memiliki 2 terminal output, dimana kedua terminal output tersebut memiliki resistansi yang dapat berubah sesuai dengan intensitas cahaya yang diterimanya. Dimana nilai resistansi kedua terminal output LDR akan semakin rendah apabila intensitas cahya yang diterima oleh LDR semakin tinggi.

Kapasitor adalah sebuah benda yang dapat menyimpan muatan listrik. Benda ini terdiri dari dua pelat konduktor yang dipasang berdekatan satu sama lain tapi tidak sampai bersentuhan. Kapasitor dapat menyimpan tenaga listrik dan dapat menyalurkannya kembali (Halliday, D., Resnick, R., Walker, 1997)). Kapasitas dari sebuah kapasitor adalah perbandingan antara banyaknya muatan listrik dengan tegangan kapasitor.

$$
C=Q / \Delta V
$$

Menurut Halliday, D., Resnick, R., Walker (1997) besar kapasitansi dirumuskan $C=0,0885 \mathrm{~A} / \mathrm{d}$. Maka kapasitasnya dalam satuan piko farad dengan $A$ adalah luas bidang plat yang saling berhadapan dan saling mempengaruhi dalam satuan $\mathrm{cm}^{2}$ dan $d$ adalah jarak antara plat dalam satuan $\mathrm{cm}$. Bila tegangan antara plat 1 volt dan besarnya muatan listrik pada plat 1 
coulomb, maka kemampuan menyimpan listriknya disebut 1 farad. Dalam kenyataannya kapasitor dibuat dengan satuan dibawah 1 farad. Kebanyakan kapasitor elektrolit dibuat mulai dari 1 mikrofarad sampai beberapa milifarad. Resistor adalah salah satu komponen elektronika yang berfungsi sebagai penahan arus yang mengalir dalam suatu rangkaian dan berupa terminal dua komponen elektronik yang menghasilkan tegngan pada terminal yang sebanding dengan arus listrik yang melewatinya sesuai dengan hukun Ohm ( $V=I R)$. (Putra, Ngadiyono, Purnomosari,2016).

Sensor touch atau sensor sentuh ini berfungsi sebagai rangsangan yang akan mengirimkan ke arduino dan hasil output dengan indikasi LED yang menyala. Jika sensor bagian touch ditekan maka LED yang sudah dihubungkan akan menyala. Berikut diperlihatkan bentuk sensor sentuh (Gambar 2.4)
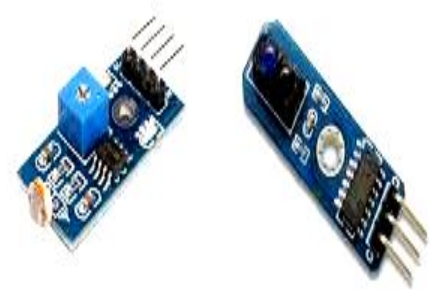

2.4 Sensor Touch (Elektro Zona,2017)

Resistor adalah sebagai pengatur dalam membatasi jumlah arus yang mengalir dalam suatu rangkaian. Dengan adanya resistor menyebabkan arus listrik dapat disalurkan sesuai dengan kebutuhan. Adapun fungsi resistor secara lengkap yaitu :

- Berfungsi untuk menahan sebagian arus listrik agar sesuai dengan kebutuhan suatu rangkaian elektronika.

- Berfungsi untuk menurunkan tegangan sesuai dengan yang dibutuhkan oleh rangkaian elektronika.

- Berfungsi untuk membagi tegangan.

- Berfungsi untuk membangkitkan frekuensi tinggi dan frekuensi rendah dengan bantuan transistor dan kapasitor.

\subsection{Metode Eksperimen}


Pada metode eksperimen dijelaskan mengenai alat dan bahan, skema percobaan serta prosedur kerja.

Alat dan bahan dala praktikum ini dapat dijelaskan:

- 1 buah Arduino

- 1 buah project board

- 2 buah LED

- 1 buah resistor

- 1 buah sensor photocell

- 1 buah sensortouch

- Kabel male to male

- Kabel male to female

Prosedur kerja dapat dijelaskan sebagai berikut:

1. Bahan dan alat dipersiapkan.

2. Program untuk penggunaan sensor cahaya dan sensor touch dibuat pada software Arduino.

3. Resistor, led, sensor disiapkan dan dirangkai sesuai skema .

4. Program yang sudah dibuat diverisvikasi dan di-upload pada papan board Arduino.

SkemaPercobaan dapat diperlihatkan sebagai berikut (Gambar 2.5 dan Gambar 2.6):

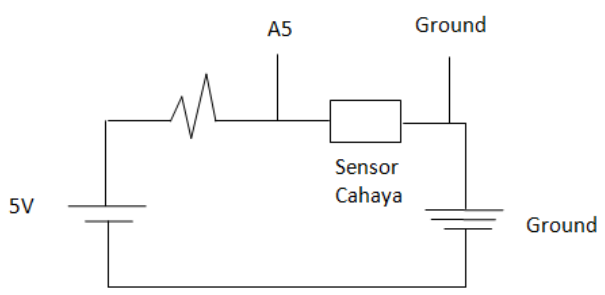

2.5 Skema Papan Board Arduino Sensor Cahaya

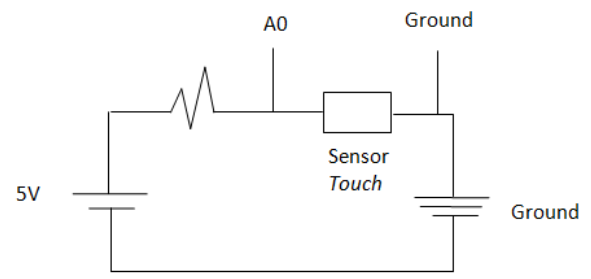

2.6 SkemaPapanBoard Arduino Sensor Touch 


\subsection{Hasil dan Pembahasan (Sebagai Contoh)}

Dapat diperlihatkan salah satu contoh program arduino yang dapat digunakan

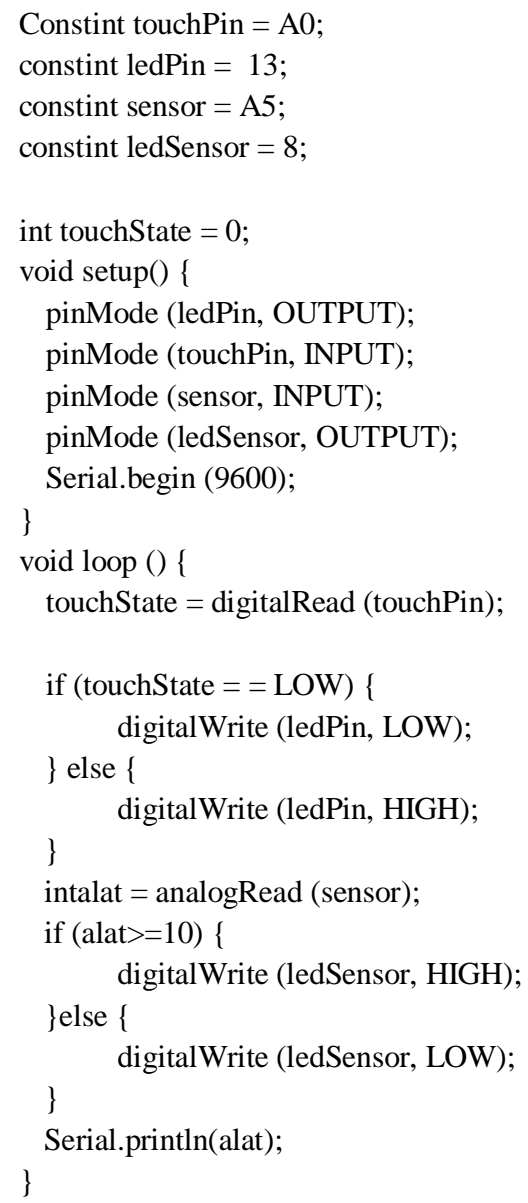

Pada praktikum kali ini deksperimenkan dua buah sensor yaitu sensor cahaya dan sensor sentuh. Penggunaan sensor cahaya yaitu bekerja jika berada dalam suasa gelap atau redup, maka LED akan menyala sedangkan untuk sensor sentuh yaitu bekerja apabila sensor mengalami sentuhan maka LED akan menyala. Sebelum merangkai pada board, terlebih dahulu dibuat program pada software arduino. Program yang dibuat yaitu gabungan program untuk sensor cahaya dan sentuh. Indikasi program yang dibuat oleh praktikan berhasil, adalah tanda ketika program di-compile maka tidak terjadi kesalahan atau error yang dapat ditunjukan pada layar monitor. Langkah selanjutnya adalah 
praktikan merangkai sensor dan led pada board kemudian program yang sudah berhasil di-compile selnjutnya di-upload ke arduino untuk melihat rangkaian dapat berjalan dengan baik atau tidak. Berikut ini adalah hasil rangkaian sensor cahaya dan sensor sentuh (Touch) pada board Arduino yang ditunjukkan pada Gambar 2.7 di bawah ini.

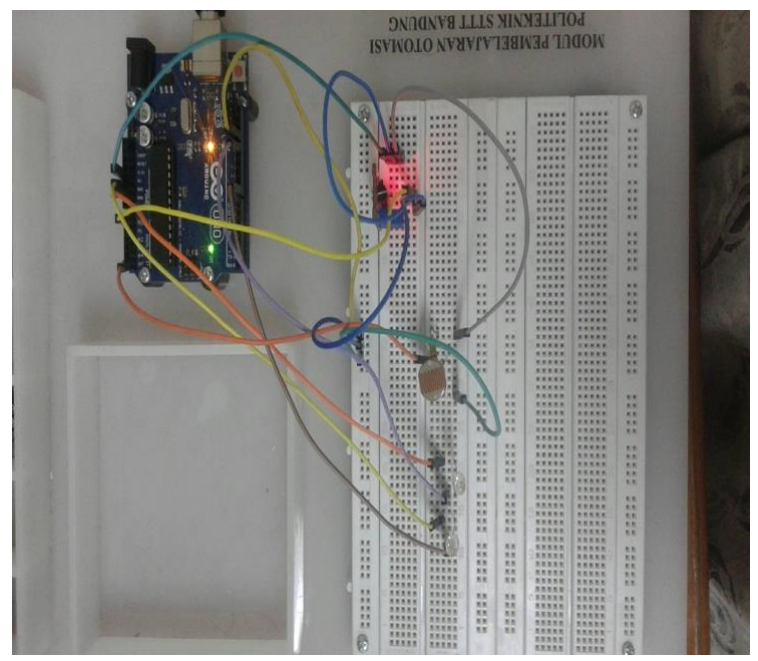

2.7 Rangkaian Sensor Cahaya dan sensor sentuh

Untuk sensor yang pertama yaitu sensor touch/sentuh telah berhasil dijalankan, dengan indikasi ketika sensor disentuh maka LED yang sudah dihubungkan menyala seperti. Pada Gambar 2.8 di bawah

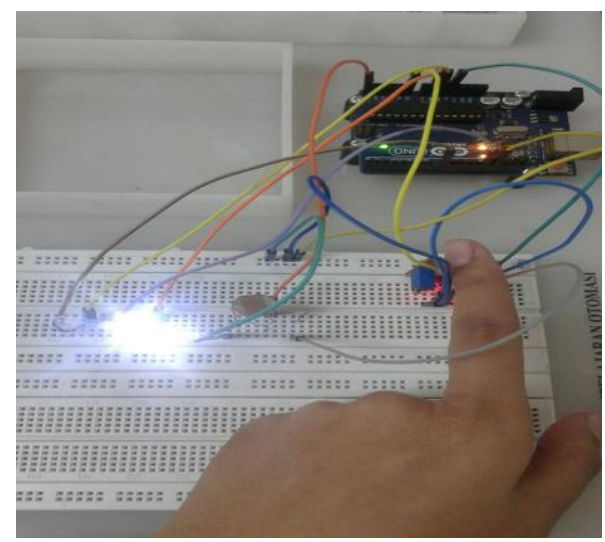

2.8 LED Menyala dengan sensor sentuh

Untuk sensor yang kedua adalah sensor $L D R /$ cahaya telah berhasil dijalankan, 
dengan indikasi ketika sensor LDR ditutup dan berada dalam kondisi redup atau gelap maka LED yang sudah dihubungkan menyala seperti. Pada Gambar 2.9 di bawah.

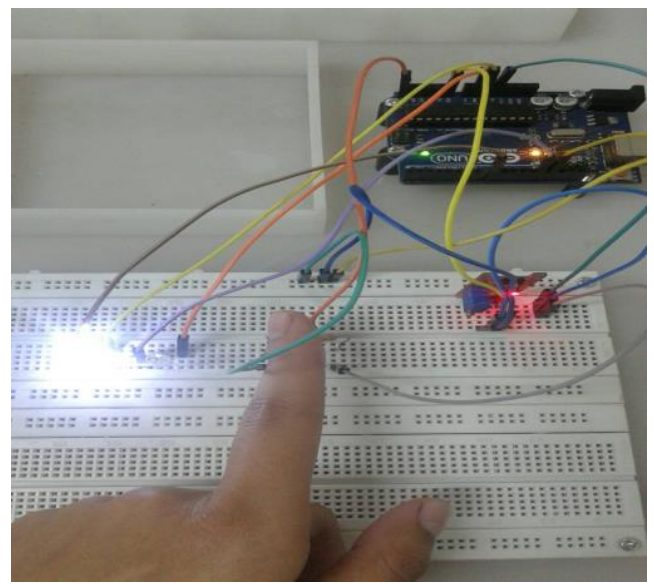

2.9 LED Menyaladengan Sensor Cahaya

Saat kedua sensor (sensor cahaya dan sensor sentuh) mendapatkan rangsangan dari luar maka kedua LED akan menyala secara bersama-sama, untuk rangkaian tersebut dapat dilihat pada Gambar 2.10 di bawahini.

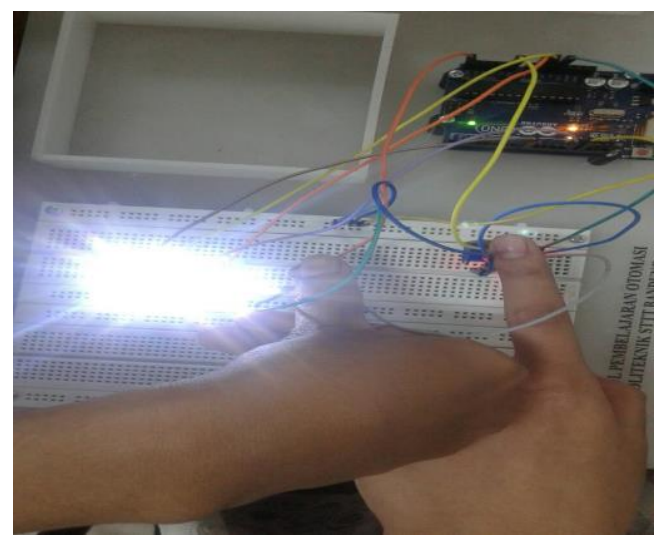

2.10 LED Menyala untuk program kombinasi Sensor Cahaya dan Sentuh

Rangkaian sensor dan aktuator pada percobaan ini telah ebrhasil dijalankan dengan baik. indikasi bahwa rangkaian dan program telah disusun dan dirancang dengan baik adalah dapat beroperasinya rangkaian dengan baik. Selain itu ada pula hal yang harus diperhatikan yaitu pada saat pembuatan program pada software Arduino, hal yang perlu diperhatikan adalah tanda- 
tanda atau simbol yang merupakan bahasa pemograman arduino, seperti misalnya tanda (;) atau jenis huruf kapital atau bukan karena sangat berpengaruh pada jalannya pembacaan program oleh Arduino.

\section{Kesimpulan}

Berdasarkan dasar teori serta hasil dan pembahasan praktikum, maka didapatkan:

Telah dibuat program sensor photocell (LDR) dan sensor touch dengan indikator LED pada board Arduino menyala

Telah dirangkaikan sensor photocell (LDR) dan sensor touch dengan indikator LED pada board Arduino menyala

\section{Referensi}

[1] _. Membaca nilai Kapasitor. Retrieved Mei 20, 2017, from Elektronika Dasar: http://elektronika-dasar.web.id/membaca-nilai-kapasitor/tabel-kode-warna-kapasitor/. 2017.

[2] Halliday, D., Resnick, R., Walker, Fundamenthal of Physics-Extended, $5^{\text {th }}$, John Wiley \& Sons, New York, 1997.

[3] Putra, VGV., Ngadiono, \& Purnomosari, E.. Pengantar Listrik Magnet dan Terapannya. Yogyakarta: CV. Mulia Jaya, 2016.

[4] _. (2017).Pengertian Arduino Board. Retrieved April 3, 2017, from Blitar Jaya:http://blitarjay.blogspot.co.id/2017/03/pengertian-arduino-board.html

[5] ElektroZona (2017). Sensor Cahaya. Retrieved April 3, 2017, from ZonaElektro: http://zonaelektro.net/sensor-cahaya/

[6] ElektroZona (2017). Sensor Touch. Retrieved April 3, 2017, from ZonaElektro: http://zonaelektro.net/sensor-touch/

[7] Putra AdiAngga (2014). Mengenal Sekilas Mikrokontroler Arduin. Retrieced April 3, 2017, from Robotid id: http://www.robotic-id.org/2014/11/mengenal-sekilasmikrokontroler-arduino.html 


\title{
ELEKTRONIKA SENSOR BERBASIS IMAGE PROCESSING
}

Dr. Valentinus Galih V.P., S.Si.,M.Sc, Endah Purnomosari, S.T., Ngadiyono, S.T., Politeknik STTT Bandung, Indonesia

\begin{abstract}
Abstrak Pada bab ini akan dijelaskan tentang dasar pengenalan pola gambar dengan menggunakan MATLAB, dasar notasi dan informasi serta contoh penggunaan terapan pada industri tekstil yang dapat digabungkan dengan mikrokontroler dengan menggunakan serial monitor untuk identifikasi sebagai sensor
\end{abstract}

Kata Kunci: image processing, elektronika sensor..

\subsection{Pendahuluan}

Penerapan ilmu Fisika dalam berbagai bidang telah banyak ditemui diberbagai lini kehidupan. Halliday, D., Resnick, R., Walker (1997) menyatakan bahwa penerapan ilmu fisika modern dapat dilihat dari berbagai pemanfaatanya di ebrbagai bidang seperti industri makanan, industri pesawat, industri persenjataan, misi luar angkasa dsb. Dalam dunia tekstil sudah mulai banyak penerapan dan penggunaan bidang fisika khususnya alat-alat elektronik dengan berbagai sensor dan aktuator berbasis mikrokontroler yang merupakan terapan dari bagian ilmu dasar dan fundamental fisika. Industri tekstil dalam penggunaannya sudah memakai berbagai sensor dan aktuator untuk mempermudah pengerjaan operator, akademisi serta praktisi dalam mempercepat dan mempermudah suatu proses produksi (Putra, Ngadiyono dan Endah, 2016).

Penerapan teknologi image processing di industri tekstil telah banyak dimanfaatkan oleh berbagai pihak seperti dalam menganalisa diameter benang, ketidakrataan benang, ketebalann kain dsb. (Putra, Ngadiyono dan Purnomosari, 2016). Praktikum pada bab ini diharapkan dapat mengembangkan pengetahuan mahasiswa untuk mengetahui cara kerja sensor visual dan dapat membuat piranti alat sensor yang dibutuhkan pada dunia pertekstilan baik dalam mesin maupun hasil produksinya menggunakan piranti MATLAB dalam menganalisa gamabr dan melakukan image processing.

Tujuan Percobaan: 
Membuat program dan menjalankan piranti sensor visual alat uji ketebalan kain tanpa adanya deformasi.

\subsection{Dasar Teori}

Suarga (2005) dan Putra, Ngadiyono \& Purnomosari (2016) menyatakan bahwa matematika diskrit adalah cabang matematika yang mengkaji objekobjek yang nilainya berbeda (distinct) dan terpisah (separate) satu sama lain. Lawannya adalah matematika menerus (continuous mathematics), yaitu cabang matematika dengan objek yang sangat mulus (smoothy), termasuk di dalamnya calculus. Komputer digital bekerja secara diskrit. Informasi yang disimpan dan dimanipulasi oleh komputer adalah dalam bentuk diskrit. Kamera digital menangkap gambar (analog) lalu direpresentasikan dalam bentuk diskrit berupa kumpulan pixel atau grid. Setiap pixel adalah elemen diskrit dari sebuah gambar. Satu pixel setara dengan $0,03 \mathrm{~cm}$ atau 0,01 inch dalam satuan panjang.

Suatu Gambar atau image dapat dipandang sebagai suatu wakilan datadata informasi diskret yang terdiri dari suatu layout (berhubungan dengan ruang) serta warna (colour). Suatu gambar digital diskret 2-D $I(m, n)$ mewakili respon dari beberapa sensor pada suatu baris yang konstan di koordinat kartesian 2-D. Indeks $m$ dan $n$ bersama-sama membentuk suatu baris dan kolom dari suatu gambar. Pixel atau suatu elemen gambar mandiri dari suatu pola gambar ditunjukkan sebagai indeks $(m, n)$ pada ruang 2-D. Mengikuti notasi pada MATLAB, maka simbol $I(m, n)$ menunjukkan $m$ baris dan n kolom dan dimulai dari atas-kiri gambar, seperti pada Gambar 3.1 di bawah
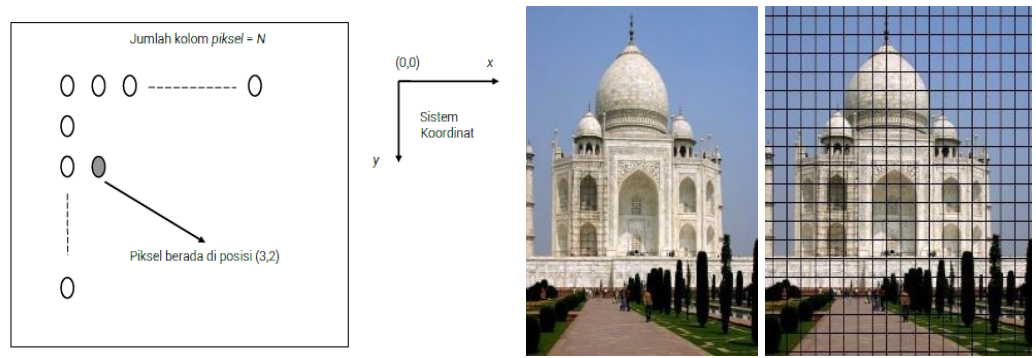

3.1 Contoh Layout dan Letak Pixel

Gambar 3.1 menunjukkan sebuah pixel mempunyai koordinat $(3,2)$ pada layar. Jumlah Pixel untuk setiap gambar tergantung dari kemampuan Graphics card. Terdapat beberapa tampilan format gambar, seperti pada Tabel 3.1 di bawah 
Tabel-1 Jumlah Pixel

\begin{tabular}{|c|c|c|c|}
\hline Standart & $x$-maksimal & $y$-maksimal & $\begin{array}{c}\text { Jumlah keseluruhan } \\
\text { Pixel }\end{array}$ \\
\hline VGA & 640 & 480 & 307200 \\
SVGA & 800 & 600 & 480000 \\
XGA & 1024 & 768 & 786432 \\
SXGA & 1280 & 1024 & 1228800 \\
\hline
\end{tabular}

Sudah dikatakan di atas bahwa warna merupakan atribut dari pixel. Selain pixel, yang lebih penting diperhitungkan lagi adalah warna dari pixel itu sendiri. Setiap pixel mengandung informasi mengenai warna dengan jumlah yang beragam. algoritma sebagai dasar penggambaran titik-titik pada raster graphics. Raster graphics diartikan sebagai grafik yang dibangun atas dasar titik-titik pada kolom dan baris yang juga mengandung informasi warna. Gambar 3.2 adalah sebuah garis lurus yang melalui titik $(x 1, y 1)$ dan $(x 2, y 2)$.

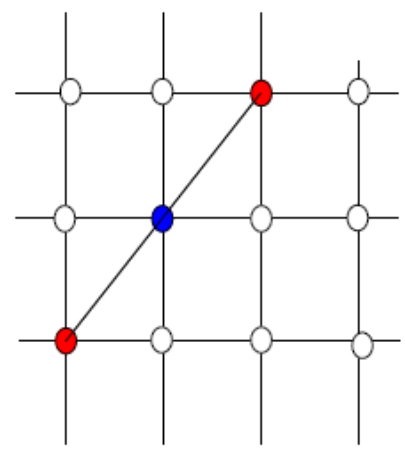

3.2 Garis Lurus

Secara umum garis lurus dinyatakan menggunakan rumusan $y=m x+C$. Dalam image processing dikenal adanya istilah Polygon yang merupakan kumpulan garis lurus yang saling menyambung hingga membentuk suatu luasan. Garis-garis ini disebut edge (sisi polygon). Titik pertemuan tiap dua sisi disebut verteks. Polygon sederhana dibagi menjadi dua yaitu convex polygon dan non convex polygon. Ciri convex polygon adalah semua sudut interiornya $<180^{\circ}$ atau setiap segmen garis yang dihasilkan dari dua buah verteks sembarang dalam polygon berada di dalam polygon. 
Bentuk polygon yang paling sederhana adalah segitiga, karena semua polygon dapat dipecah-pecah menjadi bagian yang terkecil yaitu segitiga. Mengapa polygon ? karena dengan polygon secara praktek kita bisa melakukan pendekatan untuk membentuk permukaan setiap obyek 3-D dalam grafis, pemberian warna dibutuhkan untuk mempercantik tampilan polygon. Karena itu diperlukan algoritma khusus untuk mengisi warna pada polygon tersebut. Teknik atau algoritma untuk pengisian warna pada polygon disebut filling polygon atau area filling (fillarea). Ada dua macam dasar pendekatan filling polygon pada sistem raster yaitu scan-line Polygon Fill Algorithm dan Boundary-Fill Algorithm:

Prosedur boundary-fill menerima tiga parameter yaitu: koordinat titik $(x, y)$, warna isi dan warna garis batas. Proses pengisian warna tertentu dimulai dari titik $(x, y)$, kemudian memeriksa posisi titik tetangganya, apakah titik tetangga tersebut memiliki warna batas Ada 2 macam cara untuk melihat titik tetangga, yaitu :

1. 4 tetangga, melihat titik yang berada diatas, bawah, kanan dan kiri.

2. 8 tetangga, melihat titik yang berada diatas, bawah, kanan,kiri, pojok kiri atas, pojok kiri bawah, pojok kanan atas danpojok kanan bawah.

Scan-line Polygon Fill Algorithm adalah pemberian warna pada polygon dilakukan dengan cara menscan secara horisontal dari kiri ke kanan. Hal ini dilakukan untuk mendapatkan titik potong dengan tepi polygon, kemudian mengurutkan nilai-nilai titik potong $x$ dari kiri ke kanan dan memberi warna pada pikxl-pixel diantara dua pasangan berurutan $(x 1-x 2)$.

Masing-masing pixel memberi suatu nilai pada setiap gambar yang mewakili suatu besaran fisika dalam ruang 2D (sebagai contoh adalah intensitas cahaya yang didapatkan oleh gambar pada sebuah kamera atau juga intensitas suara pada pemancar yang dapat digambarkan), namun kita dapat juga menganggap bahwa pixel tersebut berada pada ruang abstrak dimana koordinatnya berhubungan dengan sesuatu yang lebih dari ruang nyata atau fisis dan kita dapat juga memganalisa objek tersebut pada ruang yang lebih dari ruang $2 \mathrm{D}$, sebagai contoh adalah pada bidang medis yang membutuhkan rekonstruksi 3D pada organ-organ tubuh seperti gambar detak jantung yang dapat diperlakukan sebagai suatu objek 4D yaitu gabungan antara objek 3D koordinat ruang dan satu koordinat waktu. Saat kita membicarakan gambar 3D, maka dapat didiskusikan suatu ruang volume, yang disebut sebagai voxel atau volume pixel yang mewakili suatu lokasi ruang tertentu pada ruang 3D. Pada Bab ini akan dibicarakan pixel pada ruang 2D. 
31. Pengantar Praktikum Mekatronika Tekstil

\subsection{Metode Eksperimen}

Pada metode eksperimen dijelaskan mengenai alat dan bahan, skema percobaan serta prosedur kerja.

Alat dan bahan dala praktikum ini dapat dijelaskan:

- Sensor alat uji ketebalan kain

- Kain tenun

- MATLAB

- Komputer

Prosedur kerja dapat dijelaskan sebagai berikut:

1. Bahan dan alat dipersiapkan.

2. Program untuk penggunaan sensor visual dibuat pada software MATLAB.

3. Kain tenun dipasangkan pada alat uji .

4. Program yang sudah dibuat diverisvikasi dan di-upload dan diamati besar ketebalan kain.

\subsection{Hasil dan Pembahasan (Sebagai Contoh)}

Dapat diperlihatkan listing program alat uji ketebalan kain beserta hasil praktikum

$\%$ this listing program can be used by using permission of

$\%$ physics-mechatronics Lab Politeknik STTT Bandung

$\%$ Made by Valentinus Galih Vidia Putra

$\%$ Head of Physics and Mechatronics Lab Politeknik STTT Bandung

$\%$

\% ...............................

$\%$ An RGB image, sometimes referred to as a truecolor image is stored in $\%$ MATLAB as an m-by-n-by-3 data array that defines red, green, and blue color components for each individual pixel

RGB = imread('dia.png'); \% insert the file of arbitrary image

$\%$

imshow(RGB);\% show the true color as RGB

$\%$ 
\%Convert RGB image or colormap to grayscale

$\%$

$\mathrm{I}=\operatorname{rgb} 2 \operatorname{gray}(\mathrm{RGB})$;

$\%$

\%computes a global threshold (threshold) that can be used to convert an \%intensity image to a binary image with im 2 bw.

$\%$

threshold $=0.98$;

$\%$ Convert image to binary image, based on threshold

$\mathrm{bw}=\mathrm{im} 2 \mathrm{bw}(\mathrm{I}$, threshold $) ; \%$ converts the grayscale image I to a binary image imshow(bw)\% show the bw image

$\%$

$\%$ remove all object containing fewer than 10 pixels

\%using the smaller pixel, MATLAB will detect smaller image less than $0.1 \mathrm{~cm}$ $\%$

$\mathrm{bw}=\mathrm{bwareaopen}(\mathrm{bw}, 10) ; \%$ removes from a binary image all connected components (objects) that

\%have fewer than 10 pixels, producing another binary image, bw.

$\%$ fill a gap in the pen's cap

se $=$ strel('disk',1); \% making the separation of each object

$\mathrm{bw}=$ imclose $(\mathrm{bw}, \mathrm{se})$;

$\%$

$\%$ fill any holes, so that regionprops can be used to estimate

$\%$ the area enclosed by each of the boundaries

$\%$

imshow(bw)

$\%$

$\%$ traces the exterior boundaries of objects, as well as boundaries of holes

$\%$ inside these objects

$\%$

$[\mathrm{B}, \mathrm{L}]=$ bwboundaries $\left(\mathrm{bw}\right.$, 'noholes' $\left.^{\prime}\right) ; \%$ The number of objects and holes represented by $\mathrm{L}$

$\%$ Display the label matrix and draw each boundary 


\section{Pengantar Praktikum Mekatronika Tekstil}

imshow(label2rgb(L, @jet, [.1 .2 .3]))\%Convert label matrix into RGB image with value for zero-labeled elements is [. 1 . 2 .3]

hold on

for $\mathrm{k}=1$ :length $(\mathrm{B}) \%$ The statement length $(\mathrm{X})$ is equivalent to $\max (\operatorname{size}(\mathrm{X}))$ and Length of vector

boundary $=\mathrm{B}\{\mathrm{k}\}$

plot(boundary(:,2), boundary(:,1), 'w', 'LineWidth', 2)\% to make the line of boundary of object

end

stats $=$ regionprops $(\mathrm{L}$, 'Area','Centroid','Perimeter' $) ; \%$ stats is used for calculate each $\mathrm{k}$ shape

threshold $=0.98$;

$\%$ loop over the boundaries

for $\mathrm{k}=1$ :length $(\mathrm{B}) \%$ The statement length $(\mathrm{X})$ is equivalent to $\max (\operatorname{size}(\mathrm{X}))$ and Length of vector

$\%$ obtain $(\mathrm{X}, \mathrm{Y})$ boundary coordinates corresponding to label ' $\mathrm{k}$ '

boundary $=\mathrm{B}\{\mathrm{k}\}$;

$\%$ compute a simple estimate of the object's perimeter

delta_sq = diff(boundary).^2;

perimeter $=\operatorname{sum}(\operatorname{sqrt}(\operatorname{sum}($ delta_sq, 2$)))$;

$\%$ obtain the area calculation corresponding to label ' $\mathrm{k}$ '

area $=$ stats $(\mathrm{k})$.Area;

centroid $=$ stats $(\mathrm{k})$.Centroid;

keliling $=\operatorname{stats}(\mathrm{k}) \cdot$ Perimeter;

allAreas $=$ [stats.Area]; \% List of all the white areas.Create a new vector allarea, which holds the area measurement for each area

totalArea $=\operatorname{sum}($ allAreas $) ; \% 122954$

allPerimeter $=[$ stats.Perimeter $]$;

totalPerimeter $=\operatorname{sum}($ allPerimeter $)$;

$\operatorname{disp}($ 'position of object on $\mathrm{x}-\mathrm{y}$ axis $=$ ');

$\operatorname{disp}(\operatorname{stats}(\mathrm{k})$.Centroid); \% display the type of shape

$\operatorname{disp}($ 'metric of shape $=$ ');

$\operatorname{disp}\left(4 * \mathrm{pi}^{*}\right.$ area/perimeter $\left.{ }^{\wedge} 2\right) ; \%$ display the metric of shape

$\operatorname{disp}\left(\right.$ 'Area of object in micrometer ${ }^{\wedge}=$ ');

disp(num2str(area)); display the area of shape 


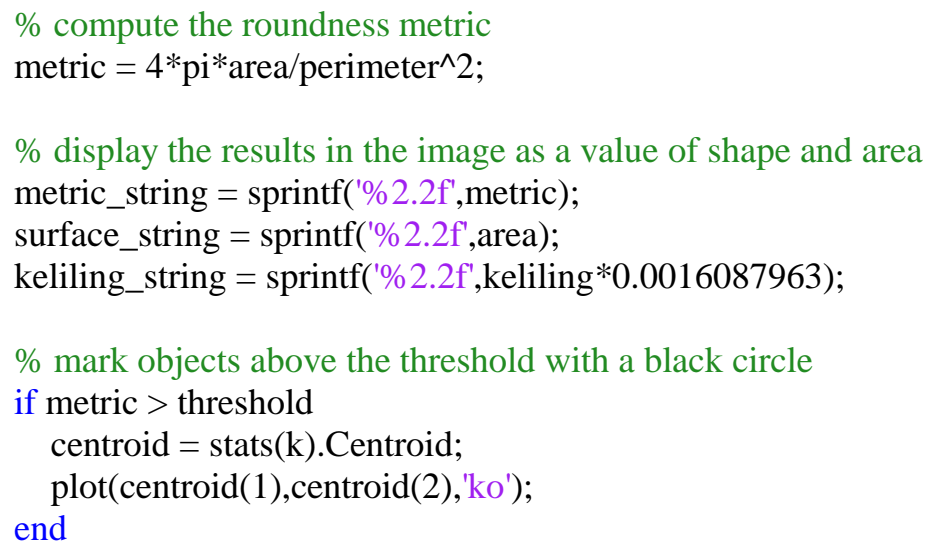

$\%$ display the value of metric and surface into image

$\%-10$ means that value moves to right, 9 means value on the top than 15

text(boundary(1,2)-10,boundary $(1,1)+40$,keliling_string,'Color','r',...

'FontSize',12,'FontWeight','bold');

$\%$ Announcement of program

$\%$ type of color can be divided as, b, c, g,k,m,r,w,y

text(size(bw,1), size(bw,1)+26,'Physics Lab Politeknik STTT Bandung ','Color','b',...

'FontSize',10,'HorizontalAlignment','right'); \% 20 axis in y as 20 using based position from above

end

title(['Object identification ',,...

'yarn diameter in $\mathrm{mm}$ ']);

figure;

subplot(2,2,1); imshow(RGB);title('Original Image');

subplot(2,2,2); imshow(bw);title('black-white Image');

subplot(2,2,3);imshow(label2rgb(L, @ jet, [.1 .2 .3]));title('processing image'); text(size (bw,1),size (bw,1)+26,'total area inside frame in pixel is ','Color','r',...

'FontSize',8,'HorizontalAlignment','right');

subplot(2,2,4); hist(allPerimeter*0.0016087963);

title('Histogram of Perimeter');

xlabel('Perimeter in pixel');

ylabel('number of object'); $\%$ show the processing image

Dapat diperlihatkan pada Gambar 3.3 di bawah hasil tampilan program 
35. Pengantar Praktikum Mekatronika Tekstil

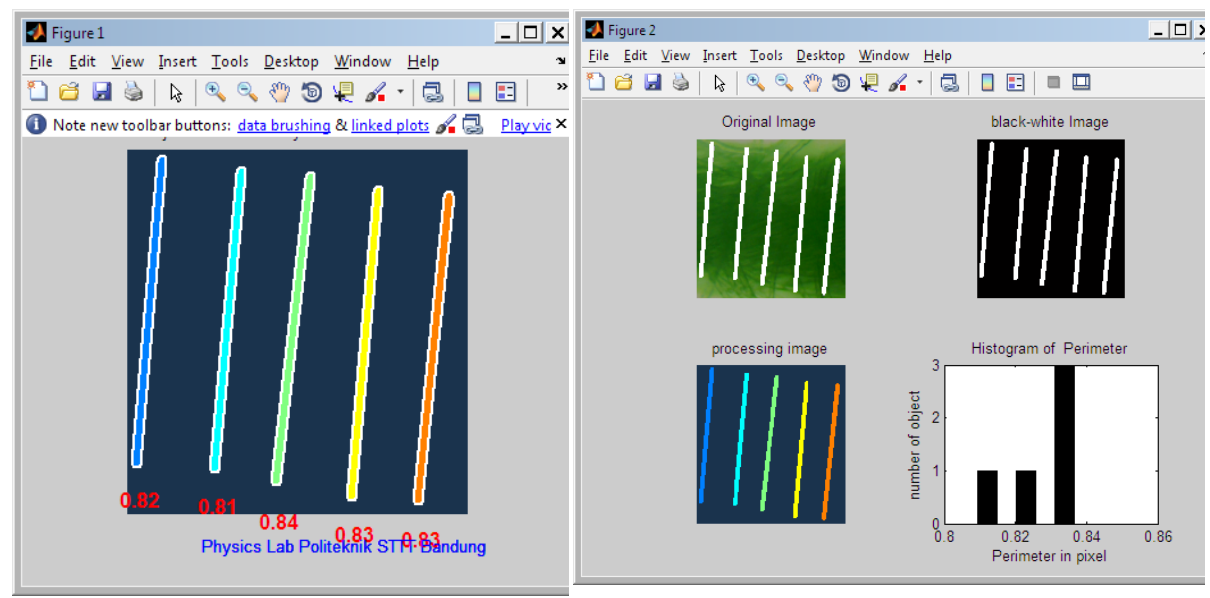

3.3. Hasil Tampilan Program ketebalan kain

\section{Kesimpulan}

Berdasarkan dasar teori serta hasil dan pembahasan praktikum, maka didapatkan hasil:

Telah dibuat program untuk menjalankan piranti sensor visual alat uji ketebalan kain tanpa adanya deformasi menggunakan MATLAB.

\section{Referensi}

[1] Halliday, D., Resnick, R., Walker, Fundamenthal of Physics-Extended, $5^{\text {th }}$, John Wiley \& Sons, New York 1997.

[2] Putra, V.G.V,, Endah dan Ngadiono, Pengantar Listrik Magnet dan Terapannya, Penerbit CV. Mulia Jaya, Yogyakarta, 2016.

[3] Suarga, Fisika Komputasi Solusi Problema Fisika dengan Matlab, Penerbit Andi, Yogyakarta, 2005. 
Dr. Valentinus Galih V.P., S.Si.,M.Sc, Endah Purnomosari, S.T., Ngadiyono, S.T., Politeknik STTT Bandung, Indonesia

\begin{abstract}
Abstrak: Pada eksperimen ini akan diberikan salah satu topik tentang instalasi listrik sederhana (contoh instalasi listrik menggunakan saklar SPST, SPDT dan PB ) yang sering digunakan dalam instalasi listrik. Pada praktikum instalasi listrik menggunakan saklar mekanik ini menggunakan bantuan software untuk memahami cara kerja rangkaian instalasi, Praktikan diminta untuk memahami rancangan rangkaian instalasi yang telah dibuat dan disimulasikan terlebih dahulu, kemudian praktikan membuat rangkaian instalasi sesuai rencana. Beban yang dikontrol pada instalasi listrik ini adalah sebuah lampu. Tujuan dari eksperimen ini adalah praktikan mempunyai kemampuan membaca dan memahami cara kerja sebuah rangkaian instalasi listrik kemudian merangkainya menjadi sebuah rangkaian instalasi listrik yang dapat digunakan untuk mengontrol beban sesuai rencana yang dibuat.
\end{abstract}

Kata Kunci: Saklar, Instalasi Listrik, SPST, SPDT, Push Button

\title{
4.1. PENDAHULUAN
}

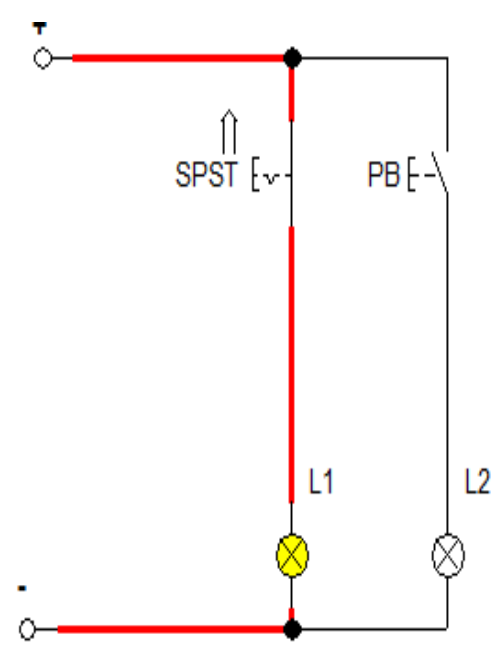

Arus listrik hanya akan mengalir pada sebuah rangkaian tertutup. Ditunjukkan pada gambar disamping dimana dari sumber arus listrik bermuatan posistif $(+)$ dihubungkan dengan sebuah saklar kemudian dihubungkan dengan sebuah beban (lampu L1 dan L2) dan sumber arus listrik bermuatan negatif (-) dihubungkan langsung ke beban. Cara kerja proses pemutusan atau penyambungan arus listrik merupakan dasar dari sebuah instalasi listrik, komponen yang berfungsi sebagai pemutus atau penyambung arus listrik pada sebuah rangkaian dilakukan oleh sebuah saklar. Saklar yang akan dipelajari pada bab ini adalah berbagai jenis saklar yang pengoperasiannya dengan cara mekanik seperti Push Button, SPST dan SPDT. 


\subsection{DASAR TEORI}

Instalasi listrik akan mengalirkan arus apabila terpenuhi syarat- syarat sebagai berikut :

Adanya Sumber Energi Listrik. Secara umum umum sumber energi listrik dibangkitkan dari generator yang digerakkan oleh air (PLTA), namun sekarang telah banyak berkembang sumber pembangkitan energi listrik memanfaatkan angin sebagai sumber gerakan untuk menggerakkan generator (PLTB), pembangkit energi listrik tenaga nuklir (PLTN), pembangkit listrik tenaga diesel (PLTD), Pembangkit listrik tenaga panas bumi (PLTP) dan pembangkit energi listrik menggunakan sinar matahari (PLTS), seperti pada Gambar 4.1

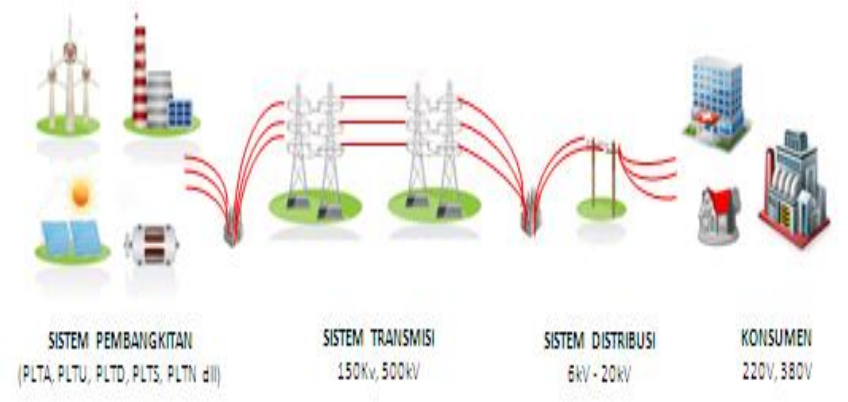

4.1 Penyaluran energy listrik

Tegangan listrik yang disalurkan kepada konsumen khususnya yang digunakan pada pelaksanaan praktikum terdiri dari dua jenis yaitu tegangan listrik 1 phase dan 3 phase, tegangan listrik 1 phase mempunyai tegangan $220 \mathrm{~V}$ dan tegangan listrik 3 phase mempunyai tegangan 220V (antara Line ke netral) dan 380V (antara line ke line). Susunan kabel pada tegangan listrik 1 phase terdiri dari dua buah kabel yaitu kabel Line dan Netral sedangkan kabel pada tegangan listrik 3 phase terdiri dari empat buah yaitu Line 1, Line 2, Line 3 dan Netral atau biasa disebut dengan R S T N. (Gambar 4.2)
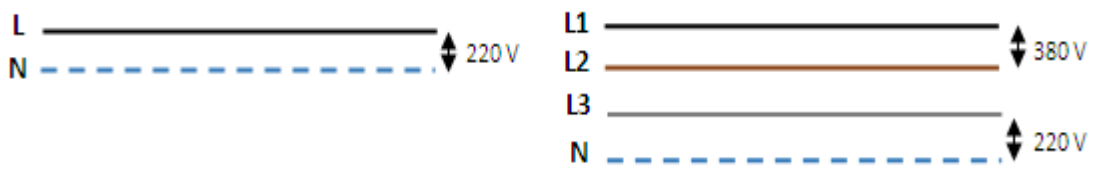

1 Phase

3 Phase

4.2 Tegangan listrik satu phase dan 3 phase 
Adanya Penghantar. Penghantar atau konduktor merupakan penghubung antara sumber dengan beban, sehingga hubungan antara konduktor dengan konduktor dan konduktor dengan perlengkapan listrik lain (saklar, stop kontak, timer, kontaktor dll) harus dilakukan dengan baik sehingga dapat dipastikan instalasi listrik yang aman dan handal. Membuat instalasi listrik yang aman dan handal dapat dilakukan dengan cara penandaan warna konduktor netral dan konduktor proteksi yang digunakan, sesuai dengan PUIL 2011 Bagian 5-52 konduktor proteksi harus berwarna loreng hijau-kuning, konduktor netral harus berwarna biru. (Gambar 4.3)

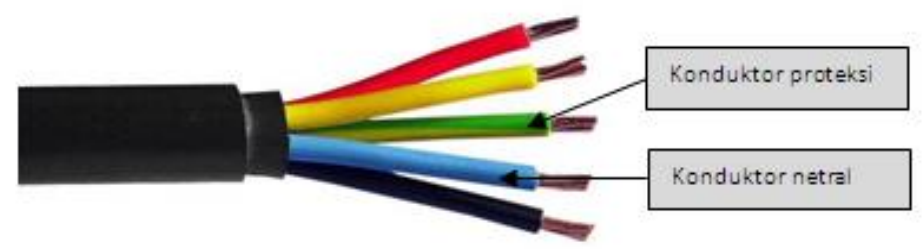

4.3. Identifikasi warna konduktor proteksi dan konduktor netral

Selain penggunaan penghantar yang sesuai dengan standar indentifikasi warna, Luas penampang sebuah penghantar juga harus diperhatikan, karena luas penghantar sebuah konduktor akan mempengaruhi kerapatan arus yang yang mengalir pada konduktor tersebut dan kerapatan arus dapat menyebabkan kenaikan temperatur pada suatu penghantar. Persamaan untuk menghitung besarnya kerapatan arus sebuah penghantar :

$$
I=\frac{I}{A}
$$

J : Kerapatan arus $\left(\mathrm{A} / \mathrm{mm}^{2}\right)$

I : Arus (A)

A : Penampang penghantar $\left(\mathrm{mm}^{2}\right)$

Sebagai contoh arus listrik 10A mengalir pada sebuah kawat berpenampang 6 $\mathrm{mm}^{2}$, maka kerapatan arusnya $1,6 \mathrm{~A} / \mathrm{mm}^{2}$, kemudian penampang penghantar diperkecil menjadi $4 \mathrm{~mm}^{2}$,maka kerapatan arusnya menjadi $2,5 \mathrm{~A} / \mathrm{mm}^{2}$ dan ketika penampang penghantar lebih diperkecil menjadi $2,5 \mathrm{~mm}^{2}$, maka kerapatan arusnya menjadi $4 \mathrm{~A} / \mathrm{mm}^{2}$, Berdasarkan contoh diatas dapat ditarik kesimpulan bahwa kerapatan arus berbanding terbalik dengan penampang penghantar. (Gambar 4.4) 


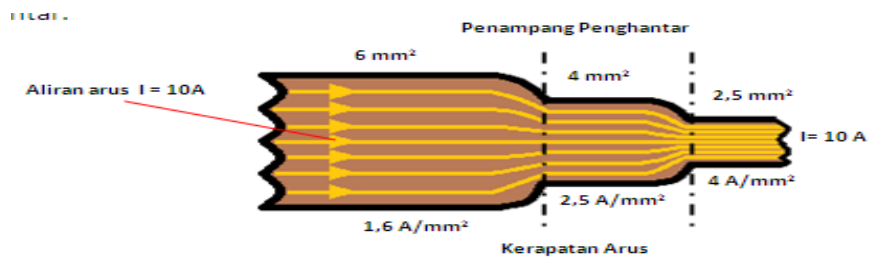

4.4. Kerapatan arus pada penghantar

Standar kemampuan hantar arus sebuah penghantar dapat dilihat secara detail pada Persyaratan Umum Instalasi Listrik Tahun 2011. Perlengkapan listrik yang lain setelah persyaratan sebuah penghantar terpenuhi antara lain adalaha saklar. Prinsip dasar cara kerja saklar adalah sebagai pemutus atau penyambung aliran arus listrik menuju beban. Definisi paling sederhana cara kerja sebuah saklar adalah sebuah peralatan untuk mengontrol aliran arus listrik pada suatu penghantar dengan cara memutuskan atau menyambungkan konduktor pada penghantar (kabel). (Gambar 4.5)
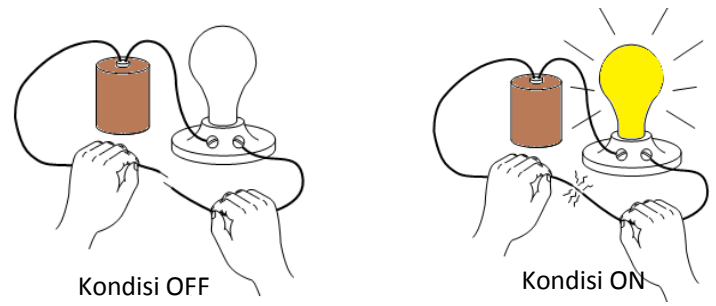

4.5. Definisi cara kerja saklar

Pada sebuah saklar dikenal beberapa istilah, yaitu Pole (terminal pada saklar yang digunakan untuk menyambungkan ke penghantar dari sumber/ input ) dan Throw (terminal pada saklar yang digunakan untuk menyambungkan ke penghantar menuju beban/ output). Berdasarkan jumlah terminal Pole dan Throw, saklar dapat dibedakan menjadi beberapa jenis, antara lain (Gambar 4.6):
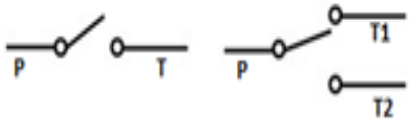

SPST

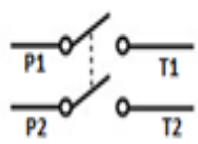

DPST

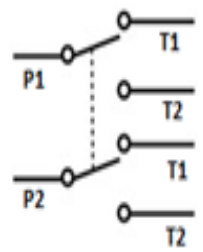

DPDT

4.6 jenis saklar menurut jumlah jumlah terminal pole dan throw 
Kondisi terminal Pole dan Throw pada sebuah saklar dibedakan menjadi dua kondisi yaitu Terhubung (Normally Close / NC) dan tidak terhubung (Normally Open / NO ), seperti pada Gambar 4.7
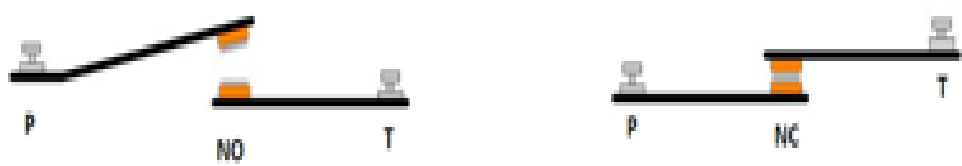

4.7. kondisi terminal NO dan NC

Sedangkan mekanisme cara kerja sebuah saklar dapat dilihat pada Gambar 4.8
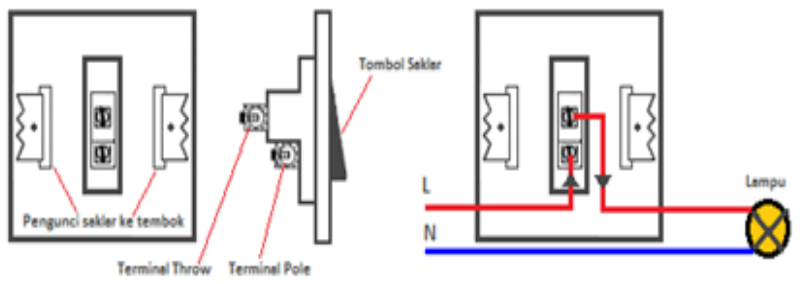

4.8. Cara kerja sebuah saklar (SPST) dan bagian-bagian saklar

Adanya Beban. Beban dalam sebuah instalasi listrik dibagi menjadi 3 jenis, yaitu :

1. Beban Resistif (R), adalah beban yang terdiri dari komponen yang mengandung sifat resistif (hambatan ohm).

contoh beban resistif : lampu pijar, kompor listrik, setrika, elemen pemanas dll.

2. Beban Induktif (L), adalah beban yang terdiri dari komponen yang mengandung sifat induktor (lilitan).

Contoh beban induktif : motor listrik, kipas angin, mixer dll.

3. Beban Kapasitif (C), adalah bebanyang terdiri dari komponen yang mengandung sifat kapasitor (menyimpan muatan listrik)

Contoh beban capasitif : capasitor.

\subsection{METODE EKSPERIMEN}

Pada metode eksperimen akan dijabarkan bagaimana metode yang digunakan serta alat dan bahan yang dipakai dalam eksperimen ini. 
Alat dan Bahan

Alat yang digunakan pada eksperimen ini adalah :

- Volt meter

- Obeng (+) dan (-)

- Tang kombinasi

- Multimeter

Bahan yang digunakan pada eksperimen ini adalah :

- MCB 1 phase

- Saklar Cam

- Saklar SPST

- Push Button

- Lampu Pijar

- Kabel Penghubung

\section{Skema Percobaan}

Mempelajari wiring diagram instalasi listrik yang direncakan : (Gambar 4.9)
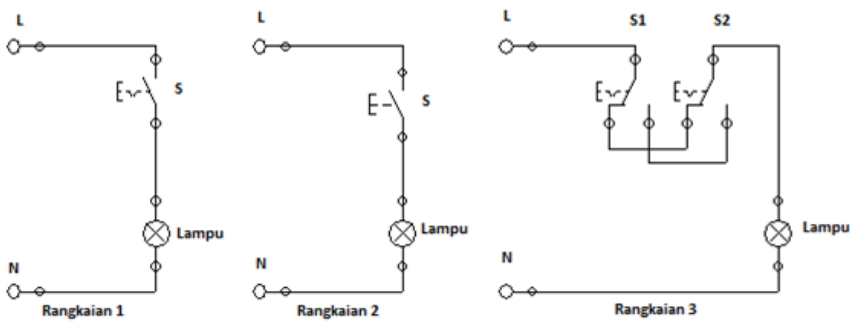

4.9. Wiring rangkaian percobaan

\section{Cara Kerja}

- Mengecek kebutuhan komponen yang terpasang pada tiap panel .

- Memasang Instalasi dengan terlebih dahulu dimulai dari titik beban. (Gambar 4.10)
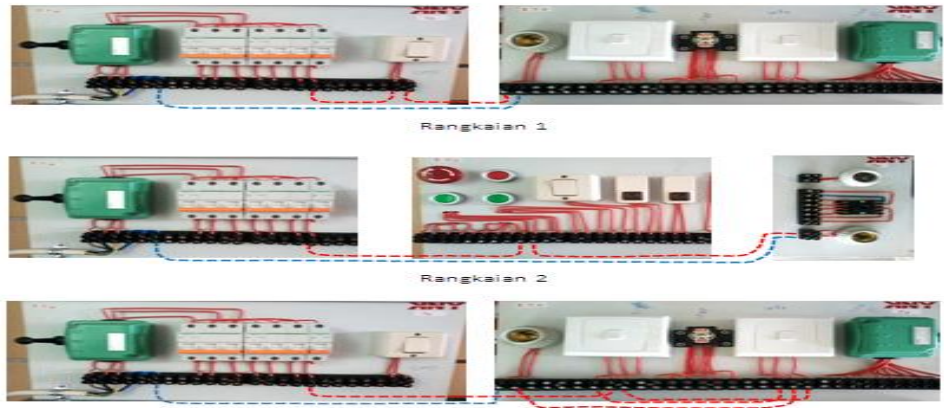

4.10. Wiring pada panel percobaan 
- Memastikan kabel phase dan netral tidak ada yang saling terhubung.

- Menganalisa cara kerja dari Rangkaian 1, Rangkaian 2 dan Rangkaian 3.

\subsection{HASIL DAN PEMBAHASAN (CONTOH HASIL EKSPERIMEN)}

Cara kerja rangkaian dengan menggunakan software :

- Rangkaian 1 $\mathrm{L}$

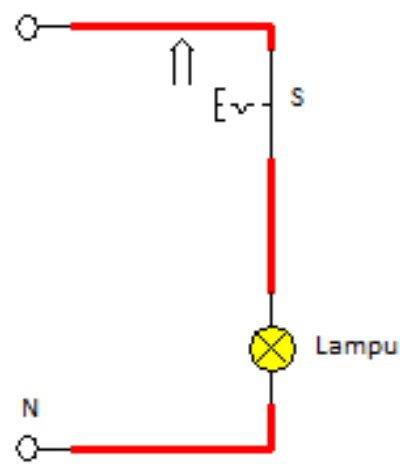

4.11. Aliran arus rangkaian 1

- Rangkaian 2

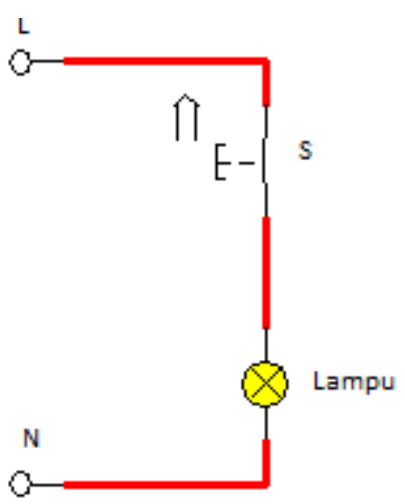

4.12. Aliran arus rangkaian 2

- Rangkaian 3
Pada saat saklar (SPST) ditekan maka kondisi saklar akan berubah dari NO menjadi NC sehingga arus listrik akan mengalir dan lampu akan menyala. Sesaat setelah saklar kita lepas, saklar akan tetap pada kondisi NC sehingga lampu tetap menyala. (Gambar 4.11)

Pada saat saklar (Push Button) ditekan maka kondisi saklar akan berubah dari NO menjadi NC sehingga arus listrik akan mengalir dan lampu akan menyala. Sesaat setelah saklar tidak kita tekan, saklar akan kembali ke kondisi NO sehingga lampu akan mati. (Gambar 4.12) 

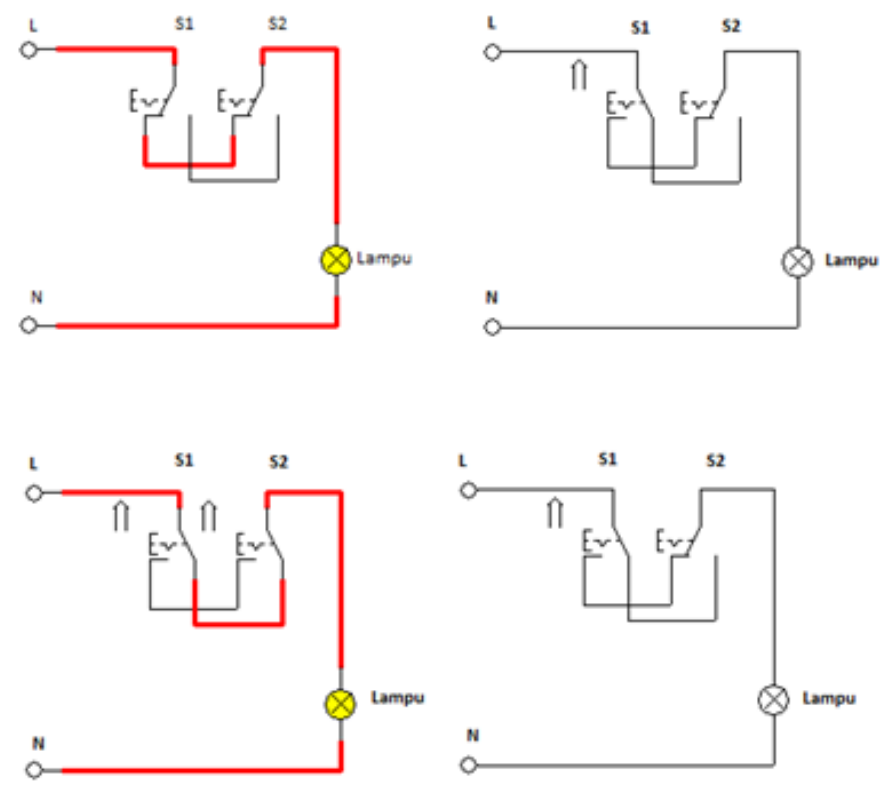

4.13. Aliran arus rangkaian 3

Pada rangkaian 3, 2 buah saklar SPDT digunakan untuk mengontrol 1 buah lampu. Lampu dapat dinyalakan dan dimatikan dengan mengoperasikan saklar (S1 dan S2) secara bersamaan atau bergantian. (Gambar 4.13)

\section{KESIMPULAN DAN SARAN}

\section{Kesimpulan}

Telah dipelajari cara membuat instalasi listrik sederhana dengan menggunakan saklar sebagai pengontrol rangkaian dan menggunakan lampu sebagai beban. Dengan pemahaman cara kerja sebuah saklar baik saklar SPST, PB dan SPDT dapat dikembangkan untuk mengontrol pengoperasian beban lainnya dari beberapa tempat.

\section{Saran}

Dapat dilakukan percobaan dengan jenis - jenis saklar yang lain sehingga praktikan akan lebih mahir dalam membuat suatu rangkaian instalasi listrik. 


\section{Pengantar Praktikum Mekatronika Tekstil}

\section{Referensi}

[1] Direktorat Jenderal Ketenagalistrikan Kementerian ESDM RI, Persyaratan Umum Instalasi Listrik Tahun 2011, Jakarta, 2014

[2] Sarjono Bambang, Rangkaian Listrik, Semarang, 2004

[3] EATON, Switch Training Manual, USA 
Dr. Valentinus Galih V.P., S.Si.,M.Sc, Endah Purnomosari, S.T., Ngadiyono, S.T., Politeknik STTT Bandung, Indonesia

\begin{abstract}
Abstrak: Pada eksperimen ini akan diberikan salah satu topik tentang instalasi listrik yang menggunakan saklar yang bekerja dengan prinsip elektromagnetik seperti relay, kontaktor dan timer yang sering digunakan sebagai komponen kontrol pada instalasi listrik. Pada praktikum instalasi listrik menggunakan saklar elektromagnetik ini menggunakan bantuan software untuk memahami cara kerja rangkaian instalasi, Praktikan diminta untuk memahami rancangan rangkaian instalasi yang telah dibuat dan disimulasikan terlebih dahulu, kemudian praktikan membuat rangkaian instalasi sesuai rencana. Beban yang dikontrol pada instalasi listrik ini adalah sebuah lampu dan motor listrik 3 phasa. Tujuan dari eksperimen ini adalah praktikan mempunyai kemampuan membaca dan memahami cara kerja sebuah rangkaian kontrol sederhana yang digunakan untuk mengontrol lampu dan kontrol starting motor listrik.
\end{abstract}

Kata Kunci: Saklar Elektromagnetik, Relay, Kontaktor, Timer, Instalasi Listrik

\title{
5.1. PENDAHULUAN
}

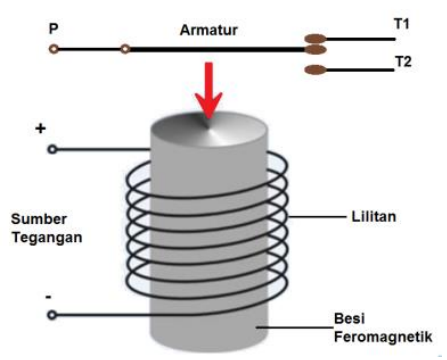

Relay, kontaktor dan timer merupakan komponen kontrol pada instalasi listrik yang bekerja berdasarkan prinsip elektromagnetik, sifat magnetik komponen tersebut dihasilkan dari lilitan yang dihubungkan dengan sumber energi listrik, pada inti lilitan ditempatkan sebuah logam yang memiliki sifat feromagnetik. Bahan feromagnetik adalah

bahan yang dapat berubah menjadi magnet dan memiliki sifat magnet yang sangat kuat, selanjutnya sifat magnet ini digunakan untuk menarik armatur yang berfungsi sebagai tuas saklar sehingga poin $\mathrm{P}$ (Pole) yang sebelumnya terhubung ke T1 (Throw 1) berubah menjadi terhubung ke T2 (Throw 2). 


\subsection{DASAR TEORI}

Komponen yang banyak digunakan pada rangkaian kontrol diantaranya :

\section{Relay}

Relay merupakan komponen kontrol yang secara umum berfungsi sebagai saklar elektromagnetik, namun ada juga relay yang prinsip kerjanya menggunakan komponen semikonduktor seperti Solid State Relay (SSR). Prinsip kerja dari relay elektromagnetik adalah apabila coil (lilitan) pada relay dialiri arus maka akan timbul gaya elektromagnetik sehingga inti besi yang terdapat dalam lilitan akan memiliki gaya elektromagnetik untuk menarik armatur, kedudukan armatur akan berubah yang sebelumnya terhubung ke T1 kemudian terhubung ke T2. Kondisi P yang tidak terhubung ke T1 disebut dengan Normally Open (NO) sedangkan P yang terhubung ke T2 disebut dengan Normally Close (NC), seperti pada Gambar 5.1

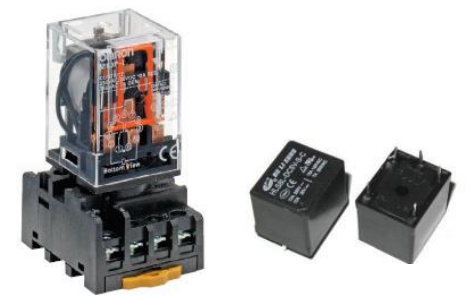

5.1. contoh relay

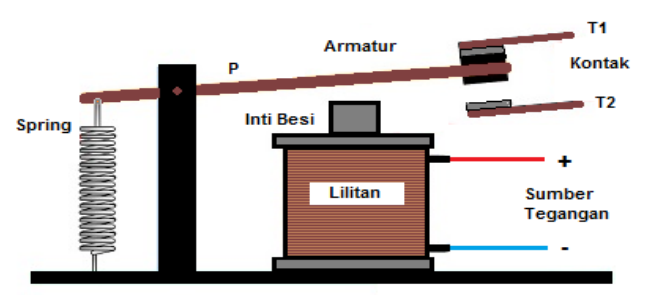

5.2. Bagian-bagian relay
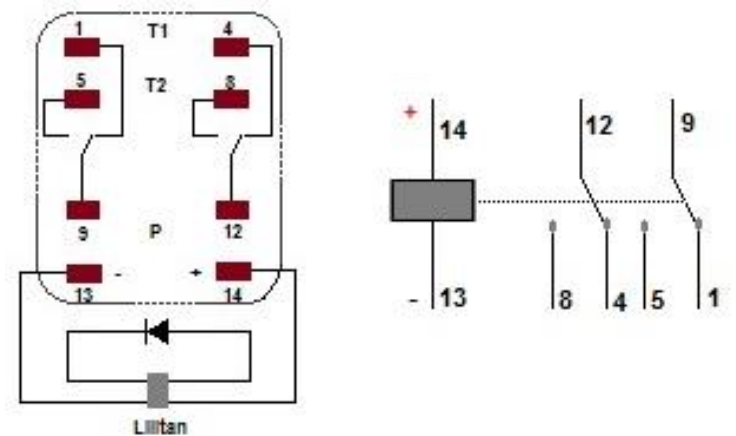

5.3. Wiring diagram relay 
Pada gambar dapat dilihat salah satu contoh wiring diagram pada sebuah relay terdapat dua buah saklar SPDT yaitu SPDT1 Pole kaki no 9 dan Throw kaki no 1 dan 5 kemudian SPDT2 pole kaki no 12 dan Throw kaki no 4 dan 8. Kontak pada kedua saklar tersebut akan berubah apabila kaki no 13 dan 14 (lilitan) dihubungkan dengan sumber tegangan.

Kontaktor Magnet (Magnetic Contactor). Kontaktor magnet merupakan saklar yang bekerja berdasarkan prinsip elektromagnetik, Lilitan (coil) kontaktor apabila dialiri arus maka akan timbul gaya elektromagnetik, gaya magnet ini dimanfaatkan sebagai penarik dan pelepas kontak utama dan kontak bantu kontaktor sehingga kontak yang kondisi awal pada kondisi NO (Normally Open) berubah menjadi NC (Normally Close) dan sebaliknya. (Gambar 5.4)

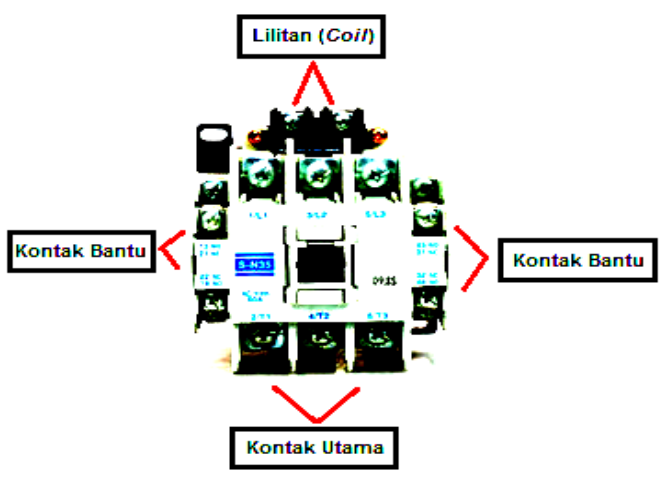

5.4. Kontaktor

Kontak utama kontaktor pada umumnya terdiri dari 3 buah kontak dalam kondisi NO sedangkan kontak bantu terdiri dari 4 buah kontak dalam kondisi NO dan NC. Kontak utama digunakan untuk mengalirkan arus 3 phasa ke beban (motor listrik) dan kontak bantu digunakan untuk mengalirkan arus bantu yaitu arus yang diperlukan oleh coil kontaktor untuk fungsi mengunci kontak (self holding), memberikan suplai arus ke rangkaian kontrol, memberikan suplai arus ke lampu indikator dan lain-lain. (Gambar 5.5)
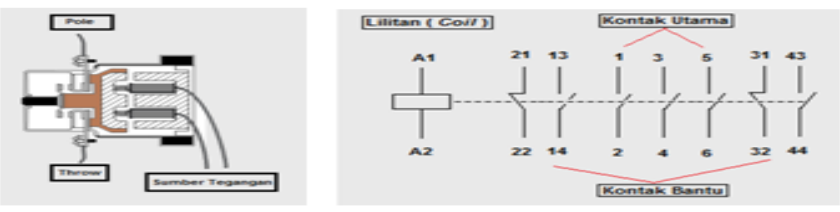
Timer (Timer Delay Relay ). Timer merupakan peratalan kontrol yang digunakan sebagai pengatur waktu atau penunda batas waktu pengoperasian bagi peralatan yang dikendalikannya. Timer bekerja dengan mengatur On Off kontak- kontaknya pada periode waktu tertentu. Pengontrolan waktu banyak dijumpai pada suatu rangkaian kontrol, sebagai contoh penggunaan timer antara lain pada rangkaian kontrol pada proses start sebuah motor listrik yang diatur dalam waktu tertentu, atau pengaturan nyala beberapa lampu dengan periode waktu tertentu seperti pada lampu lalu-lintas.Penggunaan timer pada umumnya dikombinasikan dengan peralatan kontrol lainnya, antara lain kontaktor dan relay. (Gambar 5.6)

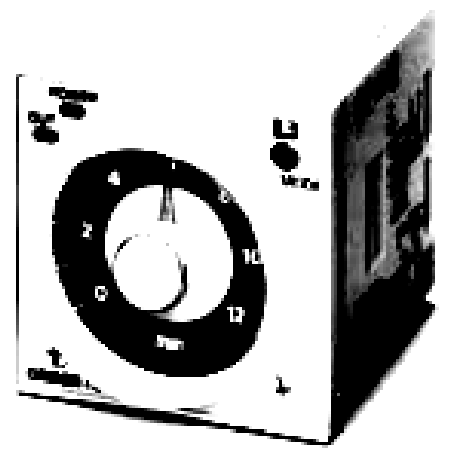

5.6. Timer Analog

Pada umumnya Timer terdiri dari delapan buah kaki (pin), kaki no. 2 dan 7 sebagai lilitan (coil) kaki yang dihubungkan dengan sumber tegangan, kaki no. 1 dan 8 sebagai pole sedangkan kaki no.3, 4, 5, 6 sebagai throw. Prinsip kerja kaki kontak output pada timer sama dengan 2 buah saklar SPDT, kondisi kontak ada dua yaitu pertama kondisi NO apabila kaki no.1 dihubungkan ke kaki no. 3 atau apabila kaki no.8 dihubungkan ke kaki no.6 ,kedua kondisi NC apabila kaki no.1 dihubungkan dihubungkan ke kaki no.4 atau apabila kaki no. 8 dihubungkan dihubungkan ke kaki no.5, seperti pada Gambar 5.7

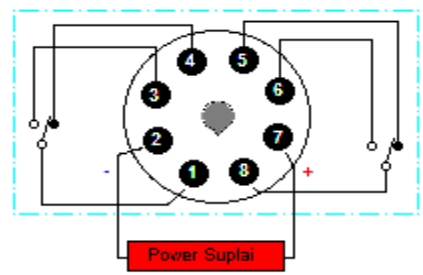

5.7. susunan kontak- kontak timer 
Timer memiliki banyak jenis baik dari cara kerja, bentuk, merk atau cara pengoperasiannya, Berikut contoh bagian- bagian dari timer Omron 8 pin, seperti pada Gambar 5.8

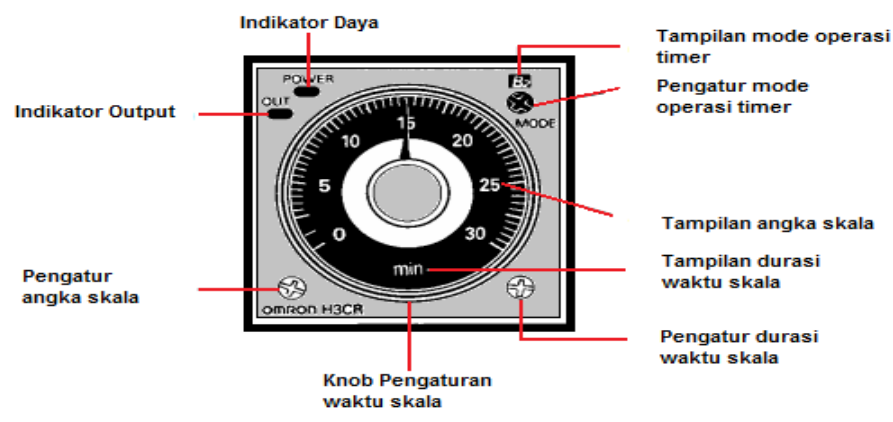

5.8. Bagian- bagian timer omron 8 pin

1. Indikator daya

Lampu indikator berwarna hijau akan berkedip apabila timer beroperasi (proses menghitung) dan akan menyala terus tanpa berkedip apabila timer berhenti beroperasi.

2. Indikator output

Lampu indikator berwarna orange akan menyala ketika hitungan timer telah tercapai atau output beroperasi.

3. Pengatur angka skala

Rentang angka skala dapat dipilih sesuai kebutuhan ( 0-1.2, 0-3, 0-12 dan $0-30)$

4. Pengatur durasi waktu skala

Durasi waktu skala dapat dipilih sesuai kebutuhan ( sec, min, hrs, dan 10h)

5. Knob pengatur waktu skala

Knob yang berfungsi untuk menentukan berapa lama waktu timer beroperasi, dioperasikan dengan memutar knob sehingga jarum skala akan berubah sesuai pilihan waktu.

6. Pengatur mode operasi

Mode operasi sebuah timer menunjukkan bagaimana sebuah timer beroperasi (saat waktu yang diseting tercapai), Berikut contoh mode operasi sebuah timer.

a) Power ON-delay

Waktu perhitungan dimulai saat sumber tegangan masuk dan output akan menyala $\mathrm{ON}$ setelah waktu tercapai.

Grafik waktu

sumber tegangan

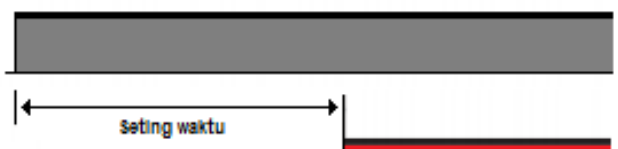

Output 
b) Signal ON-delay

Waktu perhitungan dimulai saat ada sinyal input, output akan menyala ON setelah waktu tercapai.( Sistem operasi dapat di reset dengan memberikan input pada terminal reset)

\section{Grafik waktu}

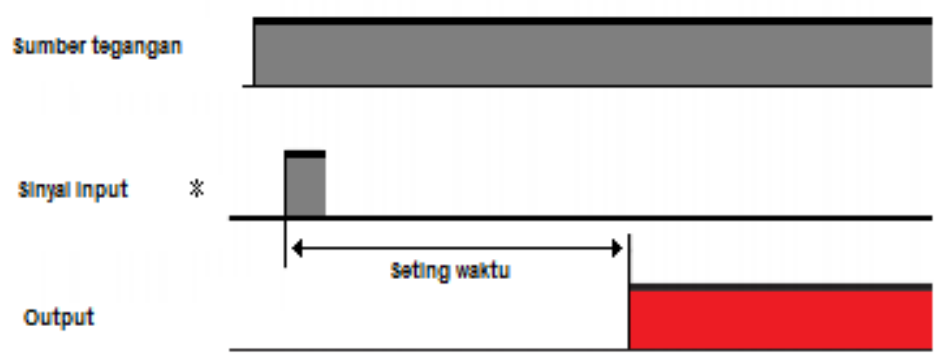

* Sinyal Input tidak dapat dlproses ketika timer beroperas!

c) Signal OFF-delay

Pada mode ini, output akan menyala ON ketika sinyal input ON. Kemudian, ketika input OFF, waktu perhitungan dimulai dan output akan OFF setelah seting waktu tercapai.

\section{Grafik waktu}

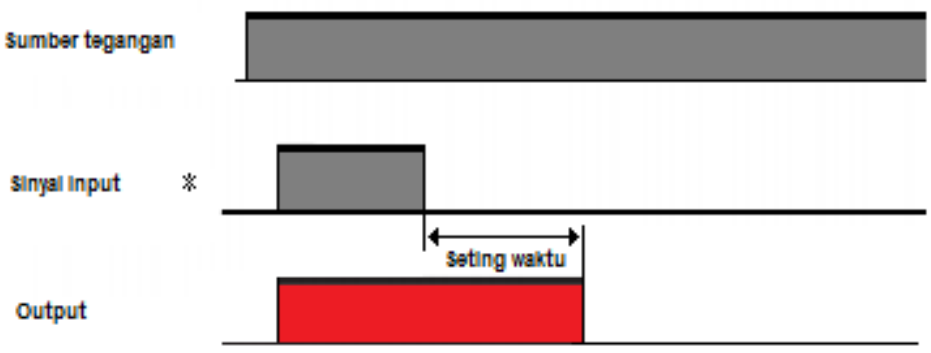

* Sinyal Input diproses bersamaan dengan output timer beroperas!

d) Interval

Seting waktu berjalan ketika sinyal input ON dan Output timer OFF setelah perhitungan seting waktu tercapai.

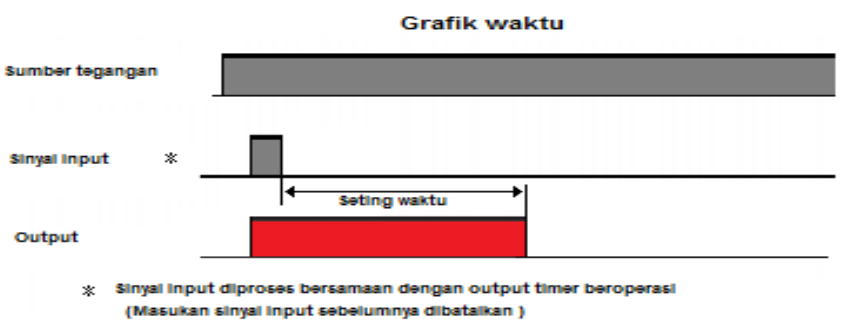


e) Flicker

Waktu perhitugan dimulai ketika sinyal input menyala ON dan output akan berulang pada kondisi ON dan OFF sesuai setingan waktu yang ditentukan.

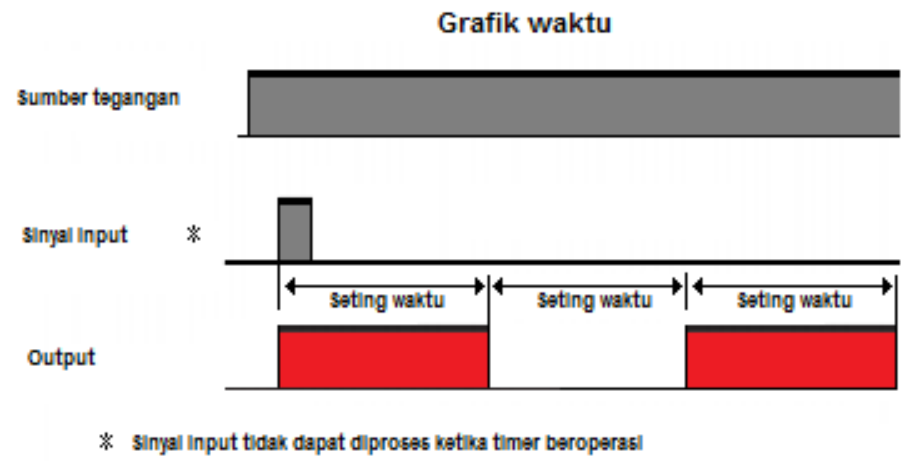

\subsection{METODE EKSPERIMEN}

Pada metode eksperimen akan dijabarkan bagaimana metode yang digunakan serta alat dan bahan yang dipakai dalam eksperimen ini.

\section{Alat dan Bahan}

Alat yang digunakan pada eksperimen ini adalah :

- Volt meter

- Obeng (+) dan (-)

- Multimeter

Bahan yang digunakan pada eksperimen ini adalah :

- MCB 1 phase

- $\mathrm{MCB} 3$ phase

- Saklar Cam

- Push Button

- Kontaktor

- Timer

- Lampu Pijar

- Kabel Penghubung

- Motor Listrik 3 phase

\section{Skema Percobaan}


52 Pengantar Praktikum Mekatronika Tekstil

Mempelajari wiring diagram instalasi listrik yang direncanakan : (Gambar 5.9)
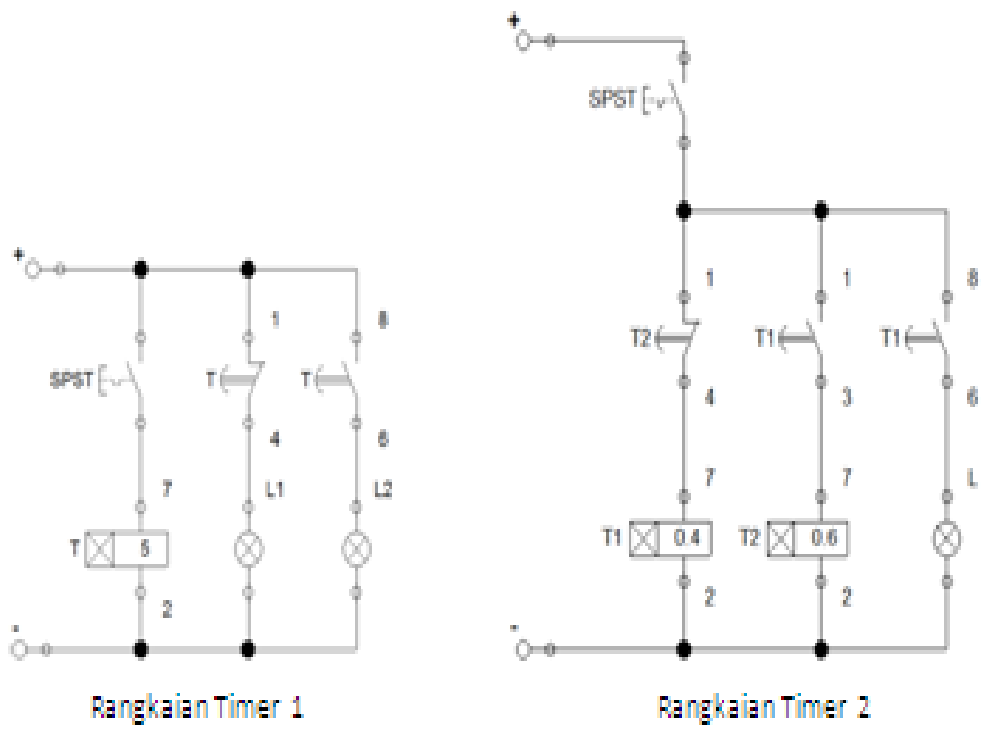

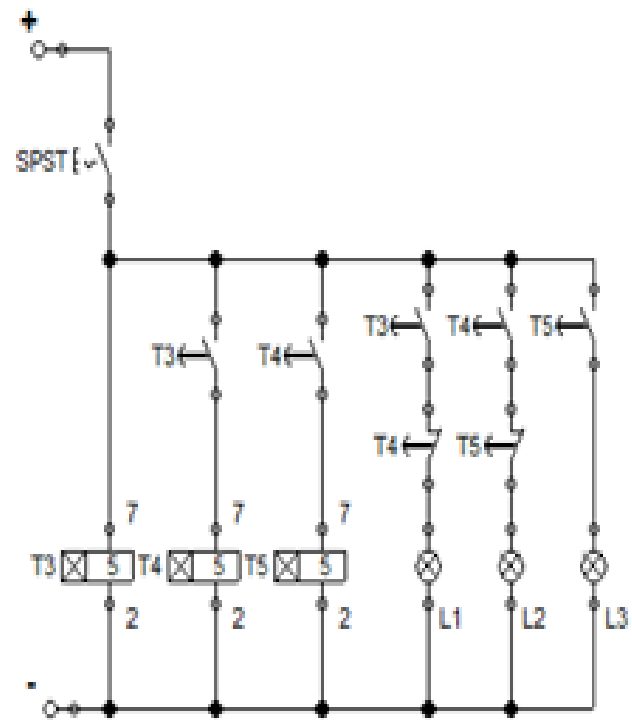

Rangkaian Timer 4

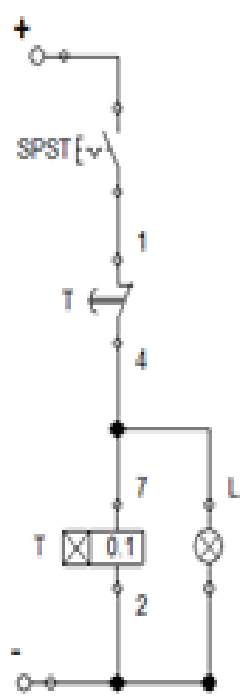

Rangkaian Timer 5

5.9. Contoh Wiring diagram Timer 


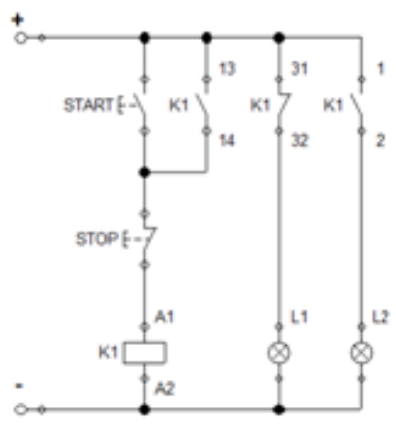

Self holding kontaktor

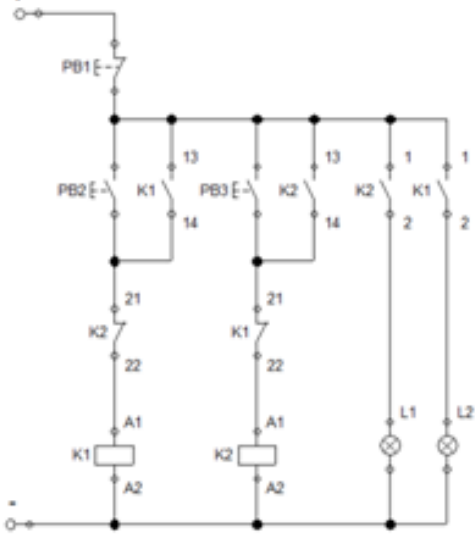

Interlocking kontaktor

5.10 Contoh Wiring diagram Kontaktor
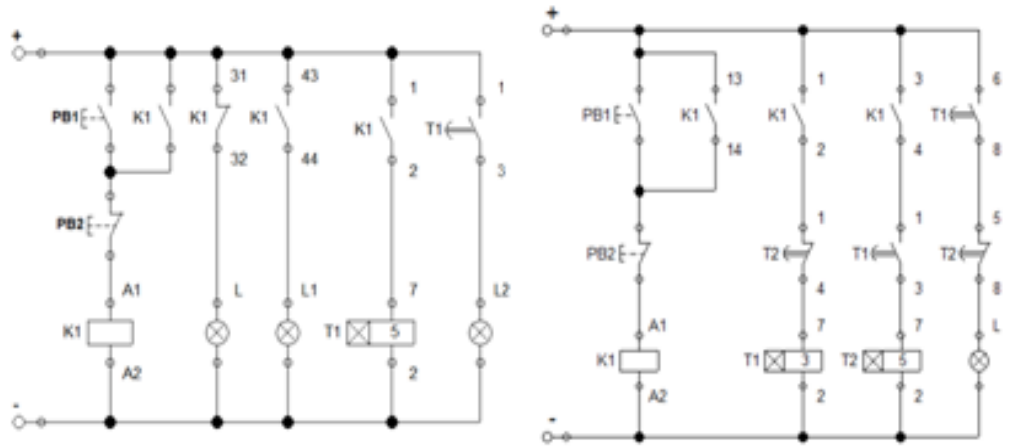

Rangkaian 1

Rangkaian 2 |
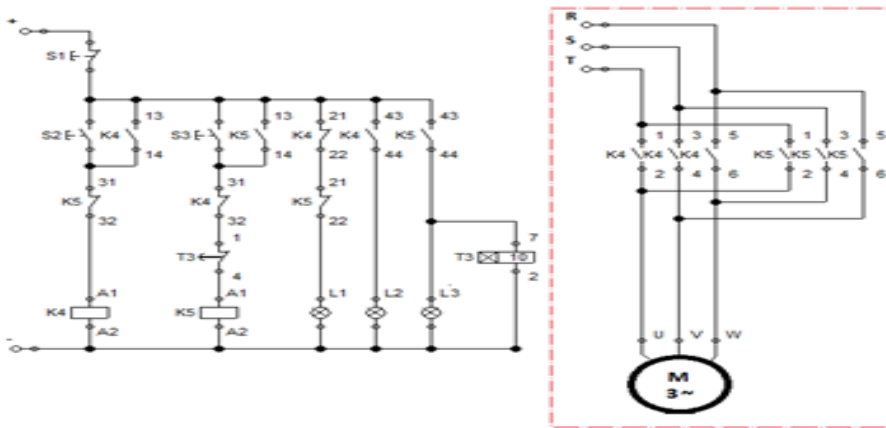

1 phase

s phase

Fangkaian 3

5.11. Wiring diagram rangkaian kontaktor-timer 
54 Pengantar Praktikum Mekatronika Tekstil

\section{Cara Kerja}

- Mengecek kebutuhan komponen yang terpasang pada tiap panel (Gambar 5.12)

- Memasang Instalasi dengan terlebih dahulu dimulai dari titik beban.

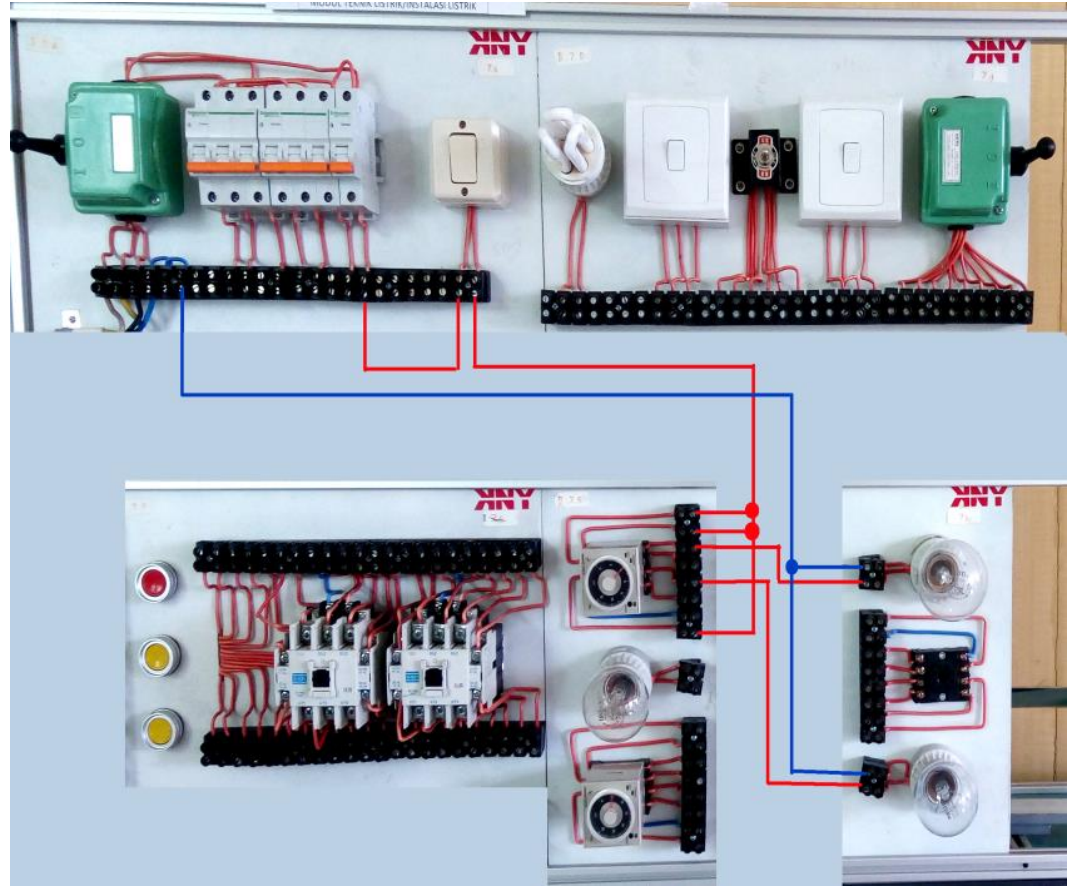

5.12. Instalasi Rangkaian Timer 1

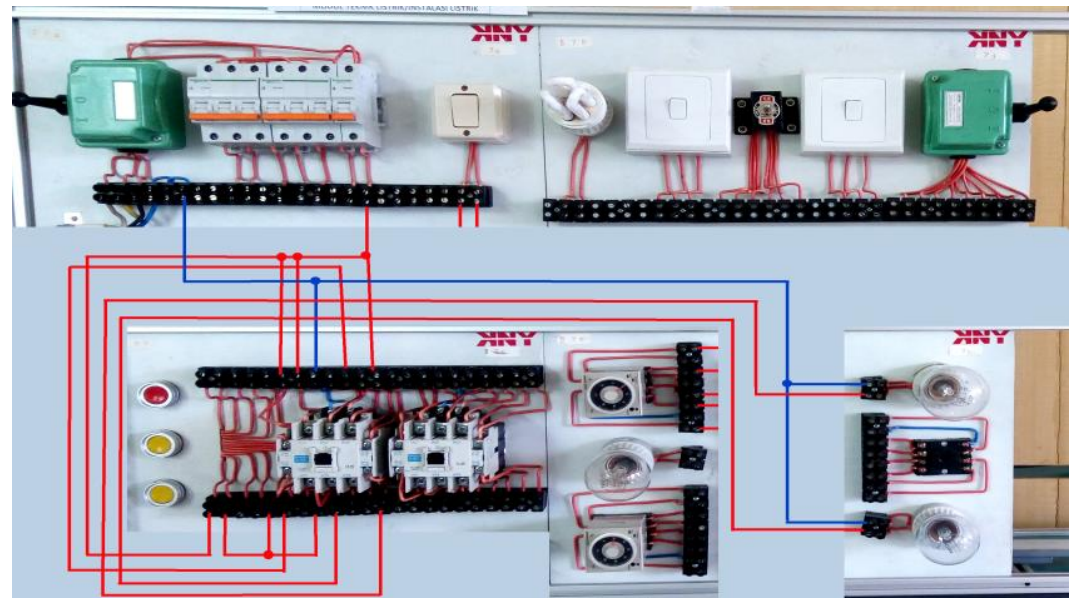

5.13. Instalasi Self holding kontaktor 


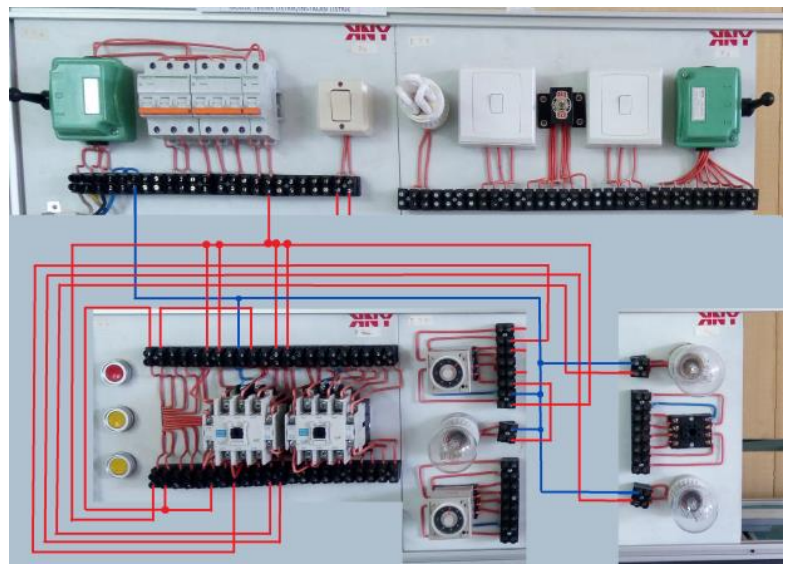

5.14. Rangkaian 1 Kontaktor-Timer

- Memastikan kabel phase dan netral tidak ada yang saling terhubung.

- Menganalisa cara kerja dari Rangkaian yang dibuat.

\subsection{HASIL DAN PEMBAHASAN (CONTOH HASIL EKSPERIMEN)}

Cara kerja rangkaian dengan menggunakan software :

Rangkaian Timer 1

Pada saat sumber tegangan disambungkan (Gambar 5. 15)

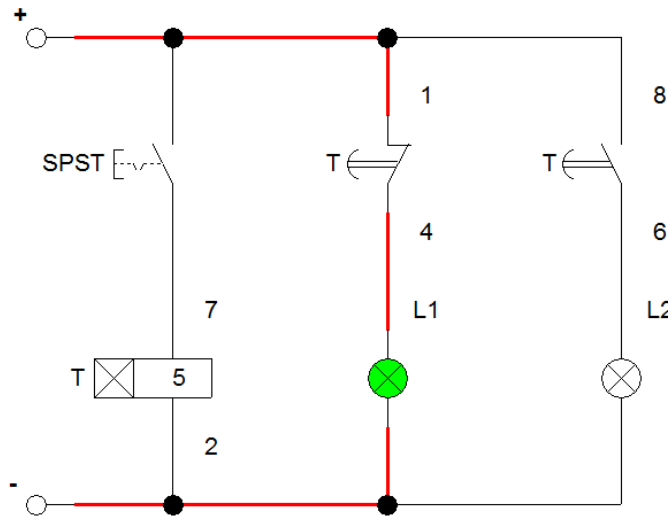

Sesaat sebuah

8 sumber tegangan disambungkan dan saklar SPST belum dioperasikan, akan terjadi aliran arus

L2 dari sumber menuju kaki timer no.1 kemudian kaki timer no.4 dan ke lampu, sehingga lampu L1 akan menyala (ON).

5.15. Aliran arus sebelum timer aktif rangkaian timer 1 


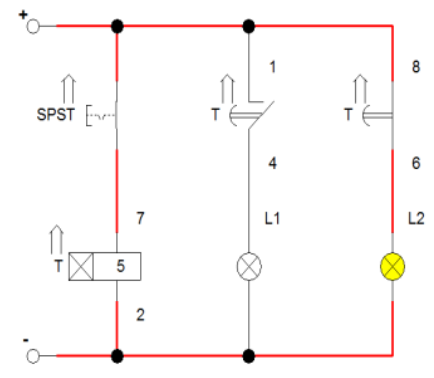

Pada saat saklar (SPST) dioperasikan maka kondisi saklar akan berubah dari NO menjadi NC sehingga arus listrik akan mengalir menujun kaki timer no.7 sehingga timer akan menghitung hingga 5detik, setelah hitungan selesai maka kotak kontak NC (kaki no. 1 no.4) akan berubah jadi NO sebaliknya kontak NO (kaki no.8- no.6) akan menjadi NC sehingga lampu LI akan OFF dan L2 akan OFF. (Gambar 5. 16)

5.16. Aliran arus setelah timer aktif rangkaian timer 1

\section{KESIMPULAN DAN SARAN}

\section{Kesimpulan}

Telah dipelajari cara membuat instalasi listrik sederhana dengan menggunakan timer sebagai pengontrol waktu pada rangkaian dan menggunakan lampu sebagai beban. Dengan pemahaman cara kerja sebuah timer dapat dikembangkan untuk mengontrol beban yang lebih banyak dan pengaturan waktu yang lebih variatif.

\section{Saran}

Dapat dilakukan percobaan pembuatan rangkaian kontrol yang lain sehingga praktikan akan lebih mahir dalam membuat suatu rangkaian kontrol sederhana.

\section{Referensi}

[1] Sirektorat Jenderal Ketenagalistrikan Kementerian ESDM RI, Persyaratan Umum Instalasi Listrik Tahun 2011, Jakarta, 2014

[2] Sarjono Bambang, Rangkaian Listrik, Semarang, 2004

[3] EATON, Switch Training Manual, USA

[4] OMRON, Model Selection Guide For Timers 


\title{
PLC (PROGRAMMABLE LOGIC CONTROL)
}

Dr. Valentinus Galih V.P., S.Si.,M.Sc, Endah Purnomosari, S.T., Ngadiyono, S.T., Politeknik STTT Bandung, Indonesia

\begin{abstract}
Abstrak: Pada eksperimen ini akan diberikan salah satu topik tentang pembuatan rangkaian kontrol sederhana menggunakan PLC. Rangkaian kontrol yang akan dibuat menggunakan perintah-perintah dasar diantaranya Bit Logic (NO, NC, Output ) dan Timer. Pada praktikum PLC Eksperimen menggunakan PLC Trainer siemen S7-200 dan software STEP 7-Micro/WIN. Praktikan diminta untuk memahami rancangan rangkaian instalasi listrik manual kemudian praktikan merubah rangkaian tersebut menjadi rangkaian kontrol PLC berupa diagram tangga (ladder diagram). Beban yang dikontrol pada eksperimen ini adalah lampu, relai dan motor DC. Tujuan dari eksperimen ini adalah praktikan mempunyai kemampuan membaca dan memahami rangkaian kontrol manual dan dapat merubah menjadi program PLC (ladder diagram).
\end{abstract}

Keyword: PLC, Siemen S7-200, Ladder diagram, Programmable Logic Control

\subsection{PENDAHULUAN}

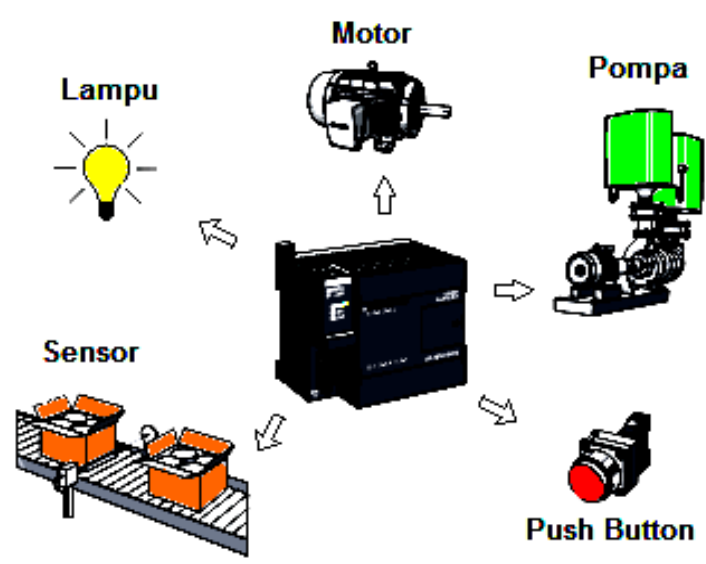

Komponen kontrol mesin pada awalnya menggunakan roda gigi, tuas dan perangkan mekanis lainnya. Seiring dengan kebutuhan akan sistem kontrol yang lebih komplek dan canggih komponen kontrol ditingkatkan dengan menggunakan instalasi

listrik, logika pensaklaran dan komponen dengan prinsip kerja relai. Penggunaan relay, logika pensaklaran dan instalasi listrik masih memiliki kekurangan, antara lain membutuhkan waktu yang lama dalam membuat serta memodifikasi sistem kontrol, Sistem kontrol juga membutuhkan ruang (panel) kontrol yang besar. Pengembangan sistem kontrol terus dikembangkan oleh industri otomotif Amerika Serikat sehingga pada periode akhir tahun 1960 s/d 


\section{Pengantar Praktikum Mekatronika Tekstil}

1970 berhasil mengembangkan sebuah perangkat pengendali logika yang dapat diprogram atau PLC. PLC memiliki beberapa kemudahan dalam pembuatan dan modifikasi pengkabelan pada sistem kontrol.

\subsection{DASAR TEORI}

Programmable Logic Control (PLC) adalah sebuah perangkat pengendali atau kontrol logika yang dapat diprogram. PLC dapat diprogram dengan menggunakan bahasa logika sendiri, bahasa pemrograman yang digunakan yaitu statement list, function block dan ladder diagram. Dari ketiga bahasa pemrograman tersebut yang paling mudah dipelajari adalah ladder diagram. Namun semakin banyak nya produsen pengembang PLC membuat kode bahasa pemrograman PLC berbeda antara produsen satu dengan lainnya, Sehingga perancang sistem kontrol harus beradaptasi dengan dasar- dasar operasi dan pemrograman yang dibuat. (Gambar 6.1)

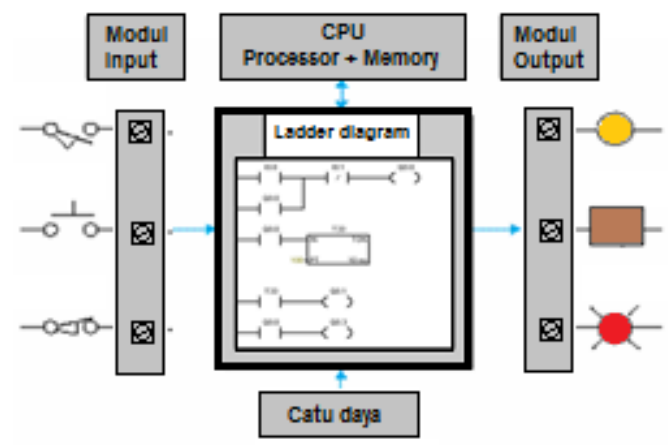

6.1. Komponen utama PLC

PLC pada awalnya berbentuk seperti sebuah papan sirkuit terbuka dan memiliki catu daya yang terpisah. Input, Output dan memory (CPU) juga tidak dapat ditambah. Namun sekarang ini PLC sudah berkembang dengan sangat pesat yang secara umum berdasarkan I/O, memori, bentuk dan ukuran PLC dapat dikategorikan menjadi PLC compact (micro) dan modular. (Gambar 6.2 hingga Gambar 6.4)

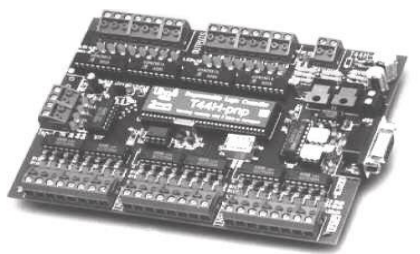

6.2. Papan sirkuit PLC

(Triangle Research Inc.,Pte.Ltd.) 


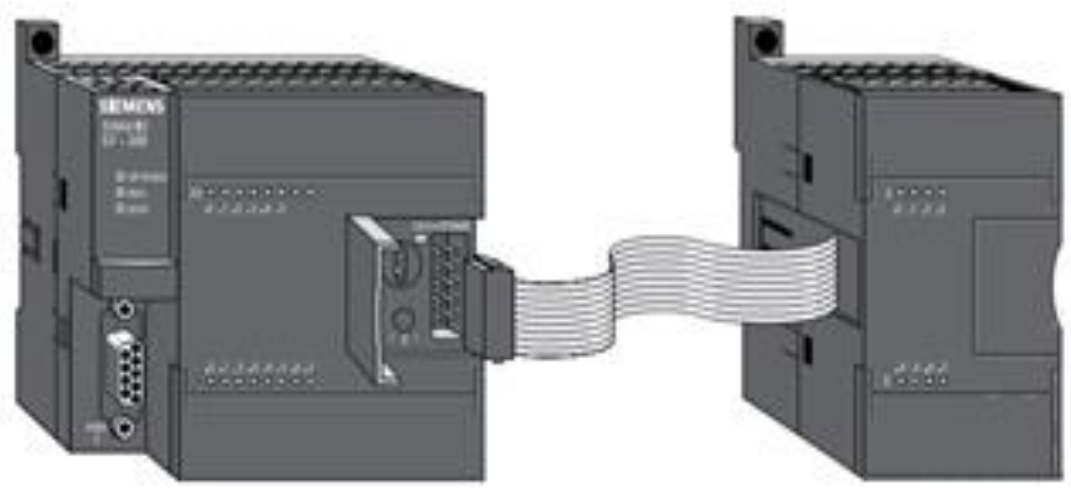

6.3. PLC Siemens S7-200

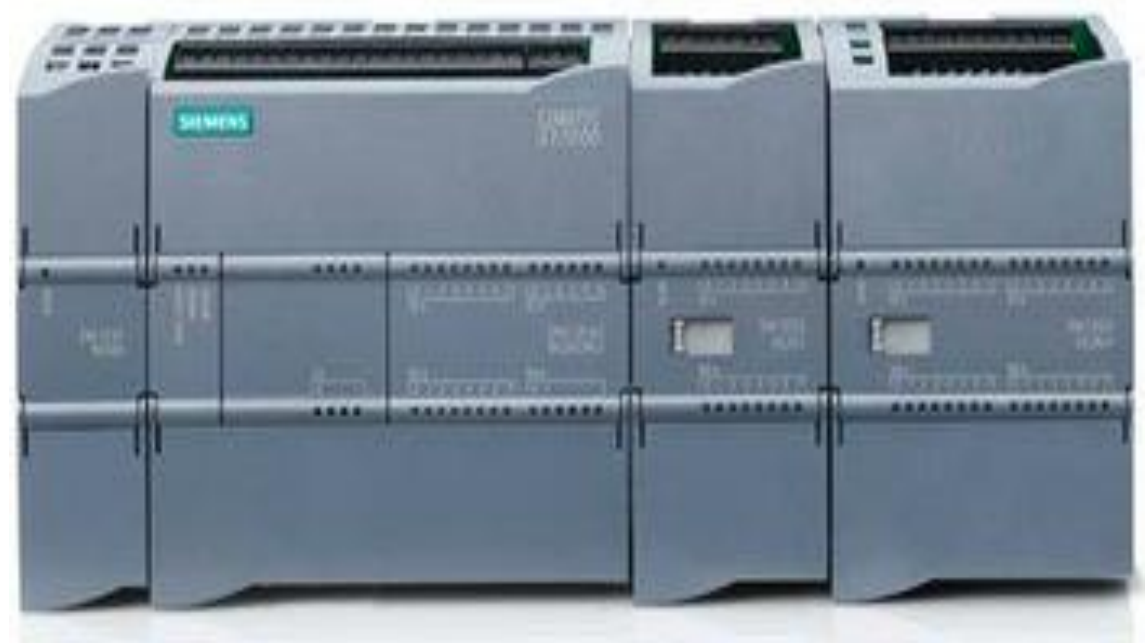

6.4. PLC Siemens S7-1200

\section{Komponen PLC}

\section{CPU}

CPU disebut prosesor pada umumnya terdiri dari mikroprosessor, memori sistem dan port komunikasi serial. CPU berfungsi sebagai penerima data program yang dari console atau komputer dan kemudian mengolah program serta mendiskripsikan menjadi output PLC, semakin tinggi prosesor akan semakin komplek program yang dapat dijalankan oleh PLC. 
Pada tabel dibawah memperlihatkan rentang memori, rentang nilai dan metode akses siemens S7-200.

Tabel 6.1 S7-200 CPU224 memori dan rentang nilai

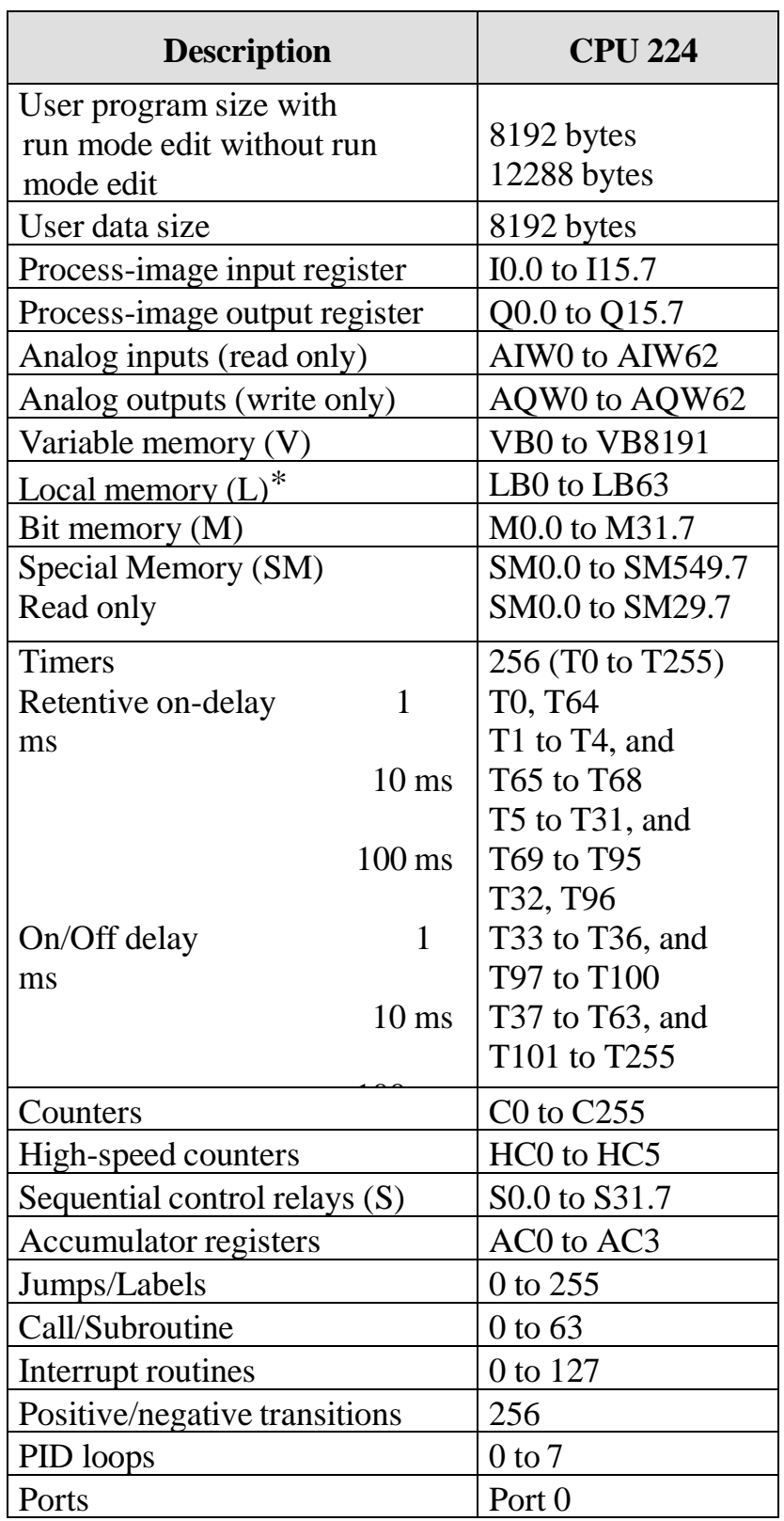


Tabel 6.2. S7-200 CPU224 cara akses program

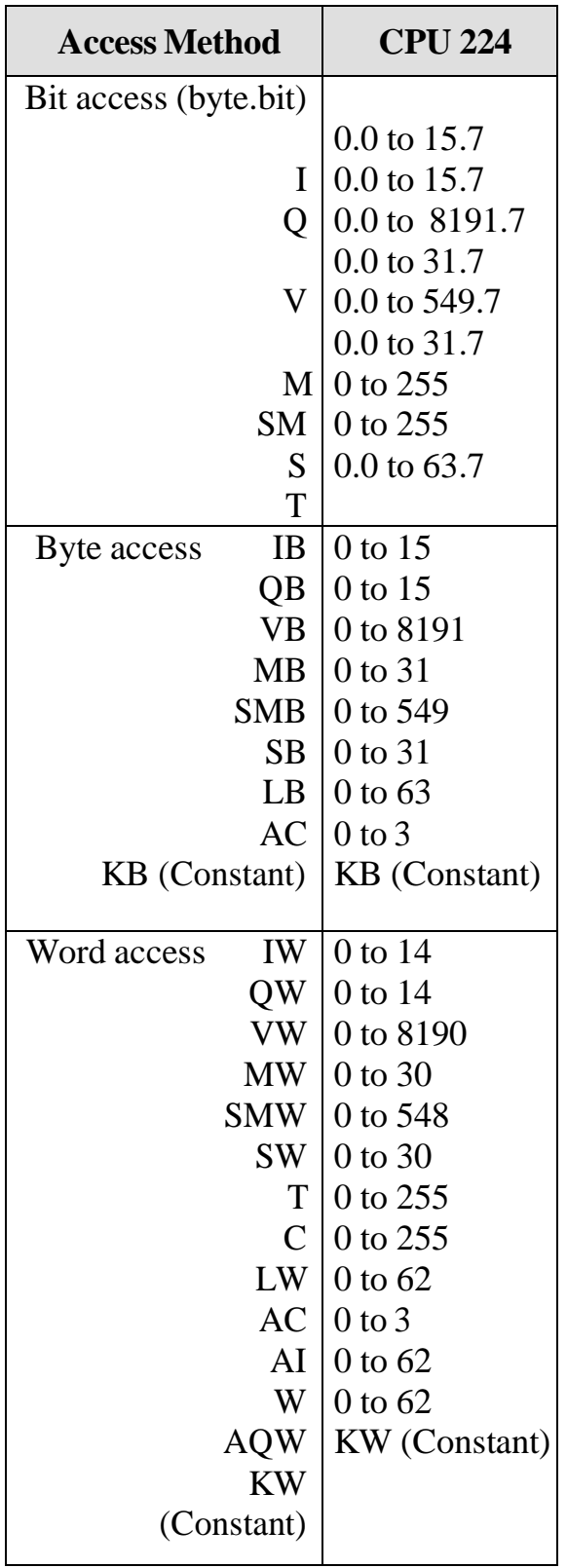


62 Pengantar Praktikum Mekatronika Tekstil

\begin{tabular}{|r|l|}
\hline Double word access & \\
ID & 0 to 12 \\
QD & 0 to 12 \\
VD & 0 to 8188 \\
MD & 0 to 28 \\
SMD & 0 to 546 \\
SD & 0 to 28 \\
LD & 0 to 60 \\
AC & 0 to 3 \\
HC & 0 to 5 \\
KD (Constant) & KD (Constant) \\
\hline
\end{tabular}

Tabel 6.3. Spesial Bits Memori

\begin{tabular}{|l|l|l|l|}
\hline \multicolumn{2}{|l|}{ Special Memory Bits } & SM1.0 & Result of operation = 0 \\
\hline SM0.0 & Always On & SM1.1 & Overflow or illegal value \\
\hline SM0.1 & First Scan & SM1.2 & Negative result \\
\hline SM0.2 & Retentive data lost & SM1.3 & Division by 0 \\
\hline SM0.3 & Power up & SM1.4 & Table full \\
\hline SM0.4 & 30 s off / 30 s on & SM1.5 & Table empty \\
\hline SM0.5 & 0.5 s off / 0.5 s on & SM1.6 & BCD to binary conversion error \\
\hline SM0.6 & Off 1 scan / on 1 scan & SM1.7 & ASCII to hex conversion error \\
\hline SM0.7 & Switch in RUN position & \multicolumn{3}{|l}{} \\
\hline
\end{tabular}

Tabel 6.4. Kode Timer

\begin{tabular}{|c|c|c|c|}
\hline Tipe Timer & No Timer & Resolusi & Nilai Maksimum \\
\hline \multirow{2}{*}{$\begin{array}{c}\text { TONR } \\
\text { (retentive) }\end{array}$} & $\mathrm{T} 0, \mathrm{~T} 64$ & $1 \mathrm{~ms}$ & 32.767 seconds \\
\cline { 2 - 4 } & $\mathrm{T} 1-\mathrm{T} 4, \mathrm{~T} 65-\mathrm{T} 68$ & $10 \mathrm{~ms}$ & 32.767 seconds \\
\cline { 2 - 4 } & $\mathrm{T} 5-\mathrm{T} 31, \mathrm{~T} 69-\mathrm{T} 95$ & $100 \mathrm{~ms}$ & 32.767 seconds \\
\hline \multirow{2}{*}{$\begin{array}{c}\text { TON, TOF } \\
\text { (non-retentive) }\end{array}$} & $\mathrm{T} 32-\mathrm{T} 96$ & $1 \mathrm{~ms}$ & 32.767 seconds \\
\cline { 2 - 4 } & $\mathrm{T} 33-\mathrm{T} 36, \mathrm{~T} 97-\mathrm{T} 100$ & $10 \mathrm{~ms}$ & 32.767 seconds \\
\cline { 2 - 4 } & $\mathrm{T} 37-\mathrm{T} 63, \mathrm{~T} 101-\mathrm{T} 255$ & $100 \mathrm{~ms}$ & 32.767 seconds \\
\hline
\end{tabular}

Dapat diperlihatkan pada Gambar 6.5 CPU PLC Siemens S7-200 


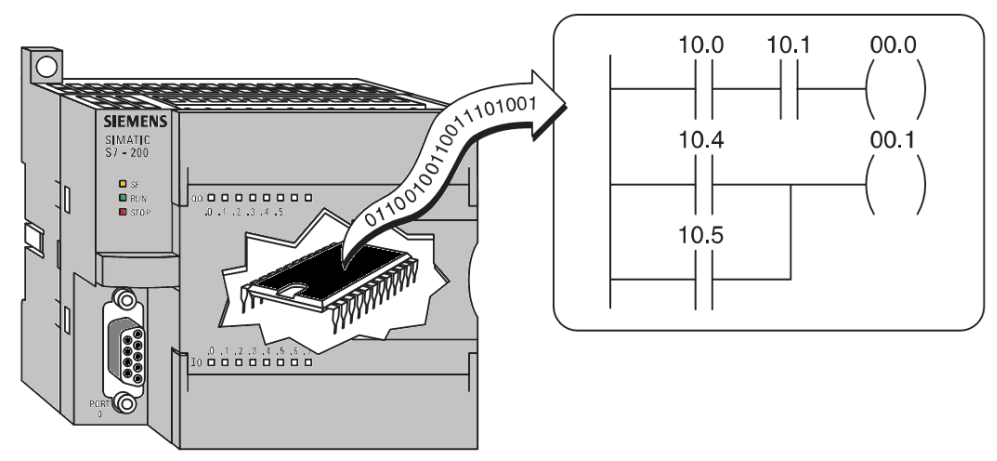

6.5. CPU PLC Siemens S7-200

\section{Modul Input dan Output}

Modul input dan output berfungsi menerima dan mentrasfer data dari dan ke PLC, semakin banyak jumlah input dan output sebuah PLC maka semakin banyak pula sensor atau aktuator yang dapat kita hubungkan ke plc sehingga program yang akan dibuat bisa lebih komplek. (Gambar 6.6)

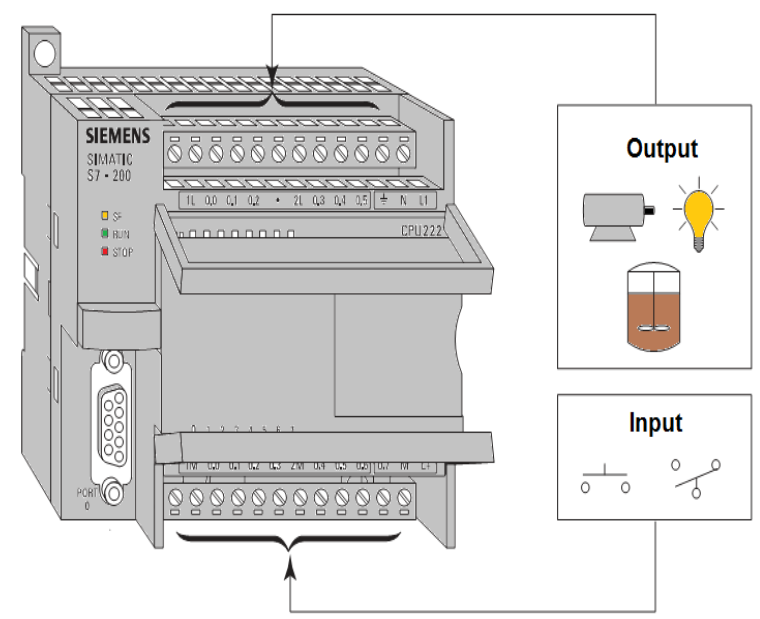

6.6. Modul Input dan output PLC Siemens S7-200

Catu Daya

Catu daya atau power suplai bersungsi sebagai pengedia daya bagi PLC, PLC yang sekarang berkembang dapat menggunakan tegangan $\mathrm{AC}$ atau tegangan 
DC. Catu daya pada sebuah PLC ada yang sudah jadi satu dengan CPU dan juga ada yang terpisah dari CPU. (Gambar 6.7)

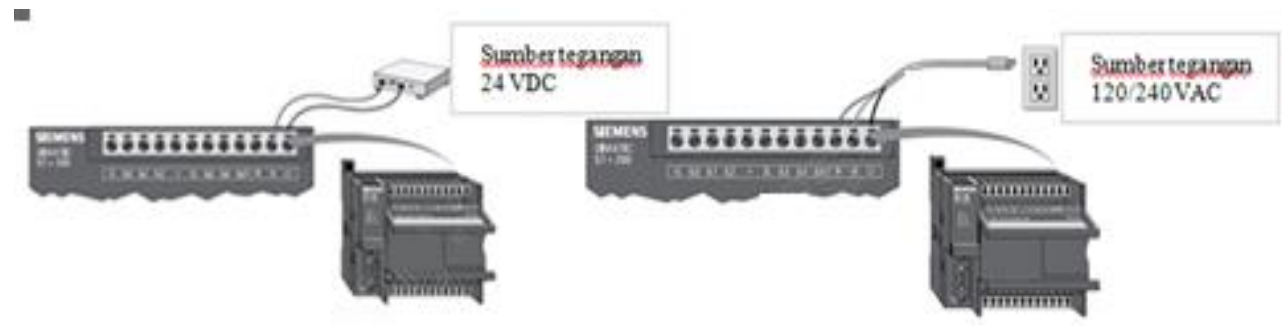

6.7. Catu daya (sumber tegangan) PLC siemens S7-200

\section{Pemrograman PLC}

Pemrograman PLC secara umum dikenal ada 3 metode yaitu Ladder Diagram, statement list dan Function block diagrams. Pada ladder diagram program dibuat dari kiri kekanan dan dari atas ke bawah (mulai dari network 1), sisi sebelah kiri ladder diagram dianggap sebagai sumber tegangan positif dan kanan negatif. Sedangkan statement list dibuat dengan memasukkan instruksi tertentu misalkan load (Start), A (AND), O (OR) dst, pada statement list ada dua baris kolom program dimana sisi sebelah kanan instruksi program, sisi sebelah kiri adalah kode memori yang digunakan dan apabila kita menggunakan function block diagram program yang dimasukkan adalah sebuah simbol berbentuk kotak, disisi sebelah kanan adalah kode port input yang digunakan, sisi sebelah kiri kode port output dan didalam kotak terdapat kode instruksi program yang dibuat. (Gambar 6.8 hingga Gambar 6.11)

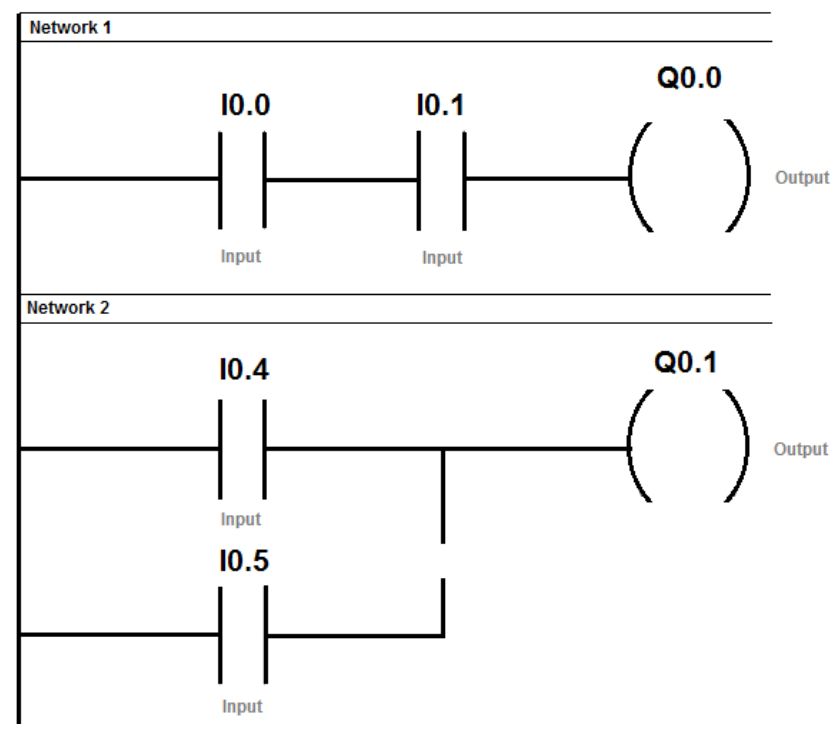

6.8 Ladder Diagram 
NETWORK 1

$\begin{array}{ll}\text { LD } & 10.0 \\ \mathrm{~A} & 10.1 \\ = & 00.0\end{array}$

NETWORK 2

$\begin{array}{ll}\text { LD } & 10.4 \\ 0 & 10.5 \\ = & 00.1\end{array}$

6.9. Statement List

NETWORK 1

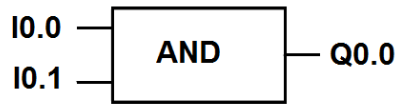

NETWORK 2

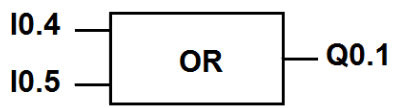

6.10. Function block diagram

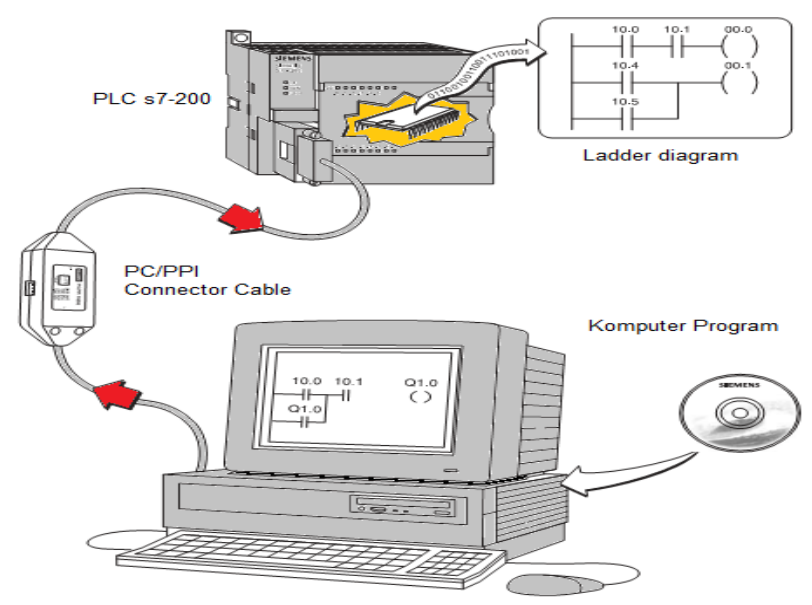

6.11 Konfigurasi Komputer ke PLC 
Salah satu konsep yang sulıt dipanamı pada saat belajar pemrograman PLC adalah adanya perbedaan antara komponen asli ( saklar, lampu, relai, kontaktor, timer, dll )dengan komponen program dan kemudian mendeklarasikan output komponen asli dengan menjadi output PLC. Untuk lebih jelasnya perubahan dari wiring diagram instalasi listrik menjadi ladder diagram bisa dilihat pada contoh rangkaian selfholding kontaktor yang digunakan untuk menyalakan dua buah beban lampu L1 dan L2 berikut (Gambar 6.12 hingga Gambar 6.13) :

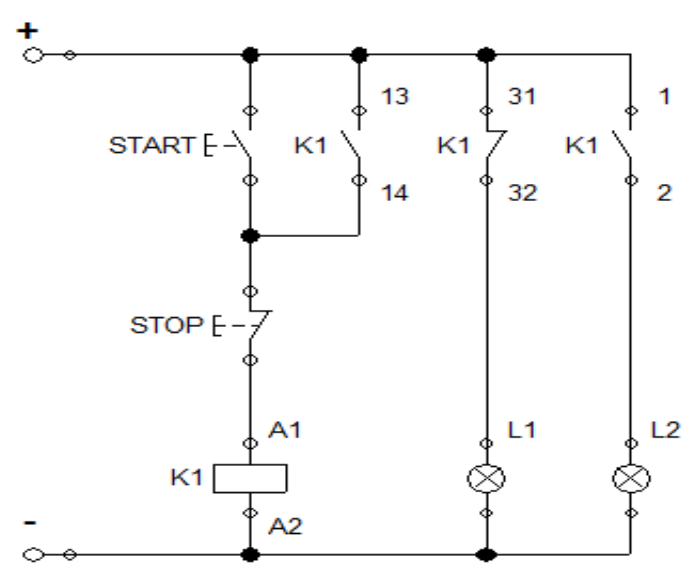

6.12. Wiring diagram selfholding

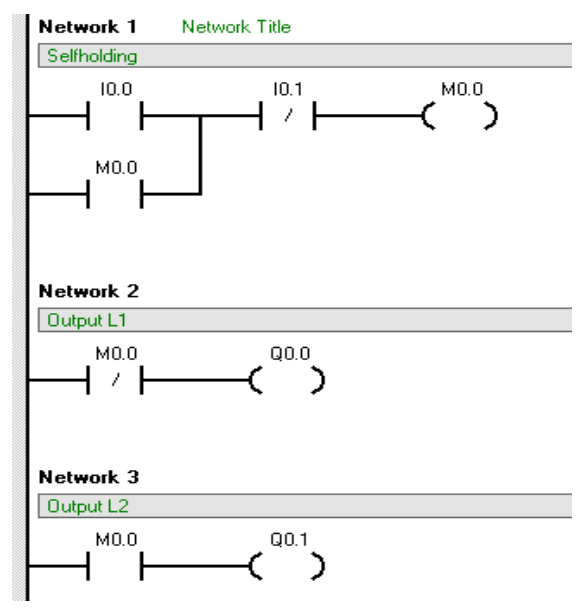

6.13. Program Ladder Diagram Selfholding 
Dari kedua gambar rangkaian selfholding diatas dapat dilihat bahwa input saklar sebagai tombol start pada ladder diagram diganti dengan kode input I0.0 NO dan tombol stop diganti dengan kode input I0.1 NC. Output kontak dari kontaktor K1 diganti dengan kode M0.0 NO dan NC, sedangkan lilitan(coil) kontaktor K1 diganti dengan M0.0. kemudian output L1 diganti dengan Q0.0 dan output L2 diganti dengan Q0.1. Setelah program selesai komponen fisik (asli) pada PLC Trainer dapat dilihat sebagaiberikut (Gambar 6.14):
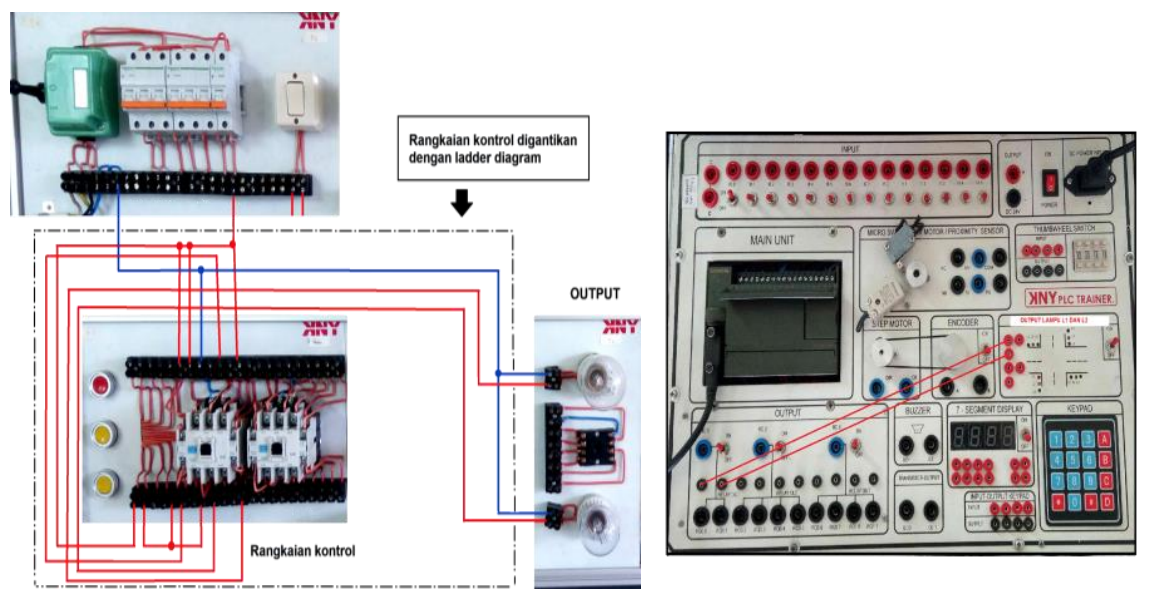

6.14. Panel wiring diagram manual dan hasil PLC Trainer S7-200

\subsection{METODE EKSPERIMEN}

Pada metode eksperimen akan dijabarkan bagaimana metode yang digunakan serta alat dan bahan yang dipakai dalam eksperimen ini.

Alat dan Bahan

Alat yang digunakan pada eksperimen ini adalah :

- Multimeter

- Obeng (+) dan ( - )

- PLC Trainer Siemens S7-200

- Power Supply

- Kabel data PC/PPI

- Komputer

- Software STEP 7-Micro/WIN

Bahan yang digunakan pada eksperimen ini adalah : 
- Kabel Penghubung

- Relay

\section{Skema Percobaan}

Mempelajari wiring diagram instalasi listrik yang ada kemudian dirubah menjadi ladder diagram (Gambar 6.15):

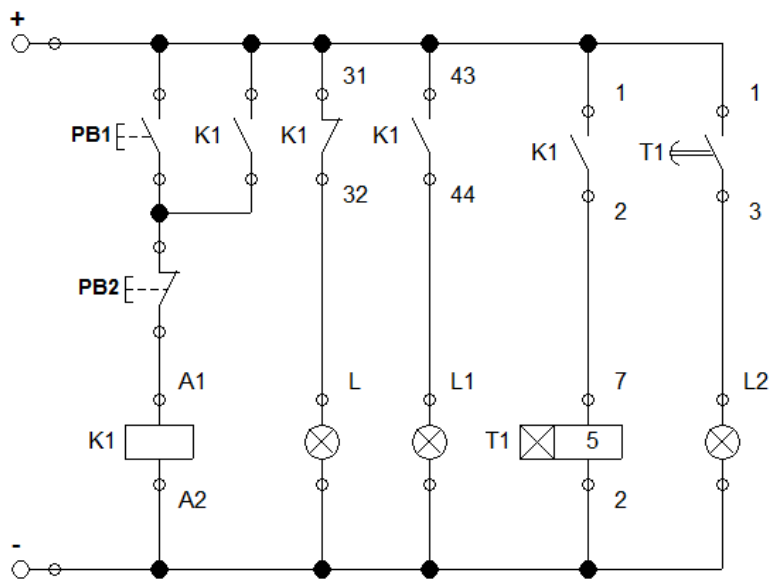

6.15. Wiring diagram instalasi kontrol lampu dengan timer

\section{Cara Kerja}

- Menganalisa berapa network hasil perubahan ke ladder diagram.

- Menganalisa kebutuhan port input dan output yang akan digunakan .

- Merancang ladder diagram mulai dari network 1 dst.

- Hubungkan kabel PC/PPI dari komputer ke PLC.

- Download program ke PLC kemudian aktifkan program status ladder diagram.

- Pasang kabel penghubung dari output PLC ke beban yang digunakan.

- Menganalisa cara kerja dari ladder diagram yang dibuat.

\subsection{HASIL DAN PEMBAHASAN (CONTOH HASIL EKSPERIMEN)}

Hasil Rangkaian ladder diagram

Cara kerja Ladder diagram : 
Input yang digunakan pada ladder diagram yaitu I0.0 dan I0.1 sedangkan outputnya M0.0, Q0.0, Q0.1 dan Q0.2. Pada ladder diagram juga terdapat satu buah timer T35 yang diseting dengan waktu 5detik. Sebelum Ladder diagram ini dijalankan maka akan ada indikator Q0.0 (Network2) yang menyala (ON) dan apabila I0.0 diberi masukan (dijalankan) arus akan mengalir ke M0.0 (Network1) dan pada network 1 akan terjadi selfholding, kontak M0.0 yang sebelumnya $\mathrm{NC}$ akan berubah jadi NO sehingga Q0.0 mati (OFF) kemudian M0.0 (Network3) akan berubah jadi NC sehingga output Q0.1 akan menyala begitu juga kontak M0.0 (Network4) akan berubah jadi NC sehingga Timer T35 akan menyala dan menghitung mundur selama 5 detik, setelah 5 detik kaki kontak timer T35 (Network5) akan berubah menjadi NC sehingga Q0.2 akan menyala (ON). Q0.1 dan Q0.2 akan mati (OFF) jika I0.1 dijalankan karena selfholding akan terputus. (Gambar 6.16)

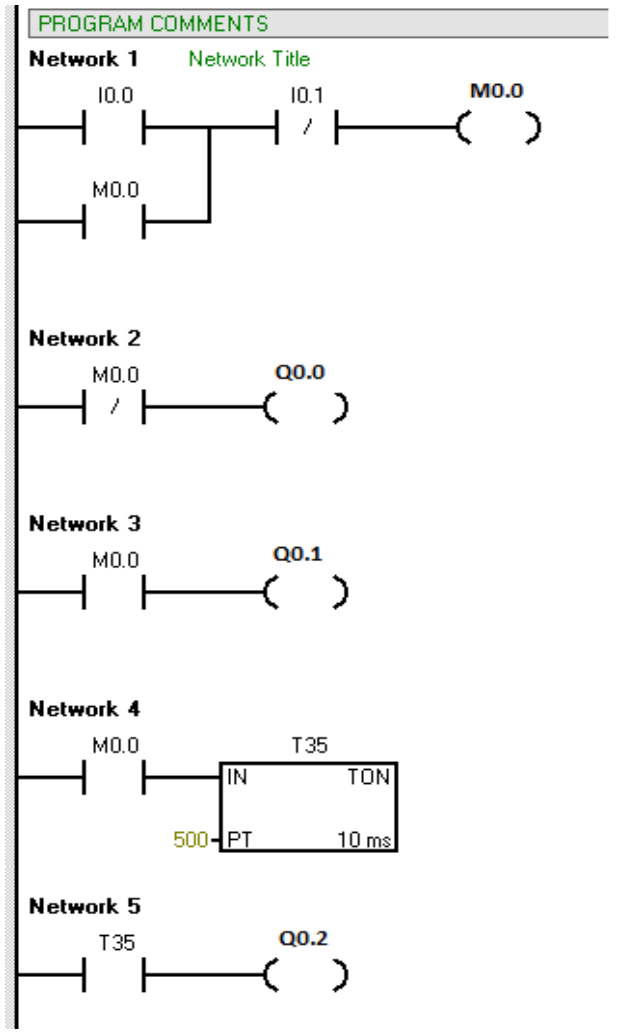

6.16. Ladder diagram

\section{KESIMPULAN DAN SARAN}

\section{Kesimpulan}




\section{Pengantar Praktikum Mekatronika Tekstil}

Telah dipelajari cara membuat rangkaian kontrol sederhana menggunakan PLC dengan menggunakan timer sebagai pengontrol waktu pada rangkaian dan menggunakan lampu sebagai beban. Dengan pemahaman cara kerja relay, kontaktor dan timer dapat dikembangkan untuk mengontrol beban yang lebih banyak dan pengaturan waktu yang lebih variatif.

\section{Saran}

Dapat dilakukan percobaan pembuatan rangkaian kontrol yang lain sehingga praktikan akan lebih mahir dalam membuat suatu rangkaian kontrol sederhana menggunakan PLC.

\section{Referensi}

[1] Hackworth R John, Jr. Hackworth D , Programmable Logic Controllers : Programming Methodes and Application

[2] Sarjono Bambang, Rangkaian Listrik, Semarang, 2004

[3] EATON, Switch Training Manual, USA

[4] Siemens, Step2000 Basics Of PLCs 


\title{
ELEKTRONIKA DIGITAL (GERBANG LOGIKA DASAR IC)
}

Dr. Valentinus Galih V.P., S.Si.,M.Sc, Endah Purnomosari, S.T., Ngadiyono, S.T., Politeknik STTT Bandung, Indonesia

\begin{abstract}
Abstrak: Pada eksperimen ini akan diberikan topik tentang tiga gerbang logika dasar yaitu AND, OR, dan NOT serta gerbang lain yang didapatkan dari hasil kombinasi gerbang dasar, gerbang logika tersebut adalah gerbang NAND, NOR, EX-OR (Exclusive-OR), dan EXNOR (Exclusive-NOR). Pada eksperimen ini praktikan akan diminta untuk menganalisa jenis IC digital dan menentukan jenis gerbang logika pada IC digital berdasarkan tabel kebenaran. IC digital tersebut kemudian digunakan untuk membuat kombinasi logika input sehingga menghasilkan sistem logika output tertentu. Hasil dari logika output eksperimen selanjutnya divalidasi dengan menggunakan teori dan software Matlab. Tujuan dari eksperimen ini adalah praktikan memiliki kemampuan untuk membuat kombinasi gerbang logika dasar sehingga menghasilkan sistem logika input dan output yang tepat.
\end{abstract}

\section{Keyword: Gerbang logika, IC Digital, Elektronika Digital}

\subsection{PENDAHULUAN}

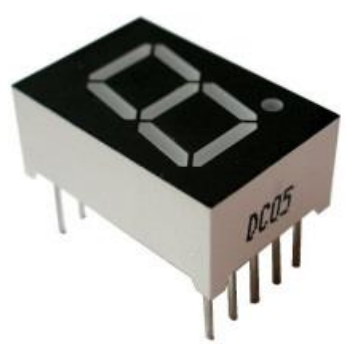

Gerbang logika dasar adalah blok dasar yang dapat digunakan untuk mengimplementasikan logika - logika dasar. Sebuah gerbang logika memiliki satu atau lebih terminal input dan satu terminal output, Terminal input dan output gerbang logika didisain hanya dalam dua kondisi yaitu bernilai high (1) atau low (0). IC gerbang logika dasar disusun dengan menggunakan transistor yang sudah dikemas dalam bentuk IC TTL (Transistor-Transistor Logic). IC TTL diberi kode standar dengan angka 74XX, dimana XX merupakan kode jenis gerbang logika didalam IC. Sebagai contoh IC TTL dengan kode 7408 yang berisi gerbang logika AND dan kode 7402 berisi gerbang logika NOR.

\subsection{DASAR TEORI}




\section{Pengantar Praktikum Mekatronika Tekstil}

IC gerbang logika dasar didalamnya minimal terdiri dari empat buah fungsi gerdang logika yang dapat dioperasikan masing - masing atau dibuat sebuar rangkaian kombinasi. Kaki IC gerbang logika dasar memiliki 14 buah pin, dimana pin no.14 berfungsi sebagai input VCC $(+)$ dan pin no.7 berfungsi sebagai input GND ( - ), sedangkan pin yang lainnya berfungsi sebagai pin terminal input dan pin terminal output. (Gambar 7.1)

\section{INPUT}

\section{OUTPUT}

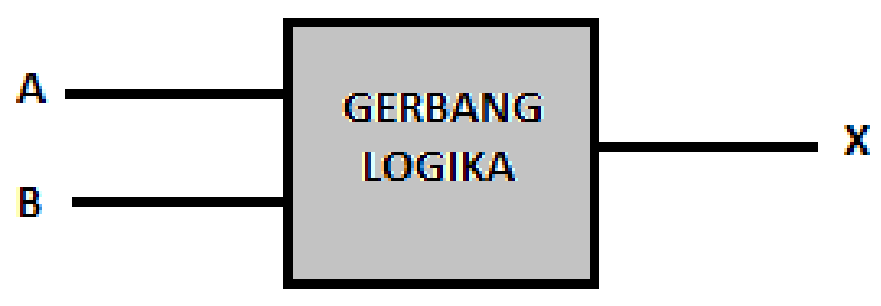

7.1. Diagram gerbang logika
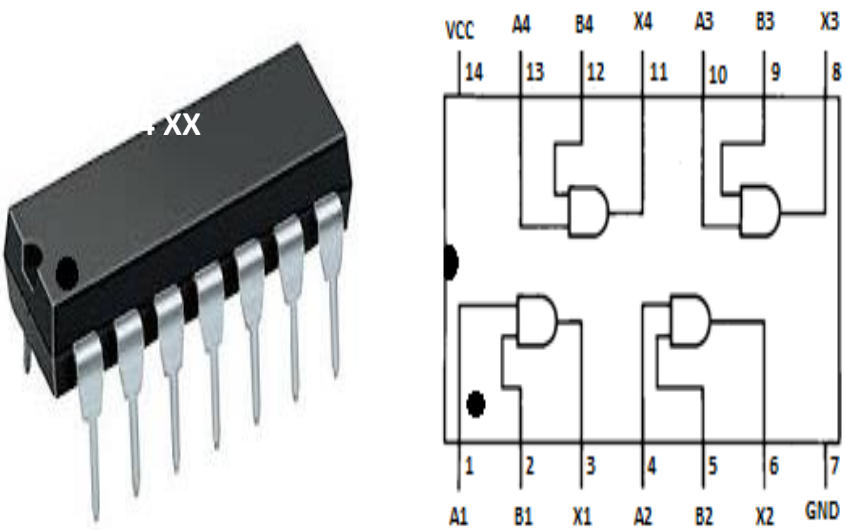

7.2. IC gerbang logika dan diagram gerbang logika pada IC

Gerbang logika dasar pada sebuah IC memiliki kondisi output yang dapat dijadikan acuan, acuan tersebut umumnya dibuat dalam sebuah tabel yang disebut dengan tabel kebenaran. Input dan output IC gerbang logika hanya mempunyai dua kondisi, yaitu high (1) dan low (0), kondisi input high dilakukan dengan cara menghubungkan terminal input (A atau B) ke $5 \mathrm{~V}$, sedangkan kondisi input low dilakukan dengan cara menghubung terminal input (A atau B) ke GND. (Gambar 7.3) 
AND

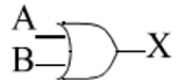

\begin{tabular}{|l|l|l|}
\multicolumn{1}{c}{$X=A+B$} \\
\hline $\mathrm{A}$ & $\mathrm{B}$ & $\mathrm{X}$ \\
\hline 0 & 0 & 0 \\
0 & 1 & 1 \\
1 & 0 & 1 \\
1 & 1 & 1 \\
\hline
\end{tabular}

OR

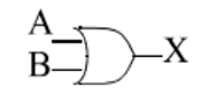

$X=A+B$
\begin{tabular}{|l|l|l|}
\hline $\mathrm{A}$ & $\mathrm{B}$ & $\mathrm{X}$ \\
\hline 0 & 0 & 0 \\
0 & 1 & 1 \\
1 & 0 & 1 \\
1 & 1 & 1 \\
\hline
\end{tabular}

NAND

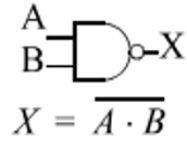

\begin{tabular}{|l|l|l|}
\hline $\mathrm{A}$ & $\mathrm{B}$ & $\mathrm{X}$ \\
\hline 0 & 0 & 1 \\
0 & 1 & 1 \\
1 & 0 & 1 \\
1 & 1 & 0 \\
\hline
\end{tabular}

NOR

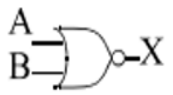

$X=\overline{A+B}$

\begin{tabular}{|c|c|c|}
\hline $\mathrm{A}$ & $\mathrm{B}$ & $\mathrm{X}$ \\
\hline 0 & 0 & 1 \\
0 & 1 & 0 \\
1 & 0 & 0 \\
1 & 1 & 0 \\
\hline
\end{tabular}

\begin{tabular}{|c|c|c|c|c|c|c|c|}
\hline \multirow{2}{*}{\multicolumn{2}{|c|}{$\begin{array}{l}\text { NOT } \\
X=\bar{A}\end{array}$}} & & EX-NOR & $-n$ & \\
\hline & & & $A$ & & & & \\
\hline A & $X$ & A & B & $X$ & A & B & $X$ \\
\hline & 1 & 0 & 0 & 0 & 0 & 0 & 1 \\
\hline 1 & 0 & 1 & $\begin{array}{l}1 \\
0\end{array}$ & 1 & 1 & 0 & 0 \\
\hline & & 1 & 1 & 0 & 1 & 1 & 1 \\
\hline
\end{tabular}

7.3. Tabel kebenaran Gerbang logika dasar

Rangkaian dari gerbang logika dasar dari yang sederhana hingga rangkaian yang komplek dapat diuraikan menggunakan operasi - operasi aljabar bolean. Ada istilah yang sering digunakan dalam aljabar bolean yaitu variabel, variabel adalah simbol yang digunakan untuk mewakili nilai gerbang logika. Setiap variabel memiliki nilai 0 atau 1 , penulisan nilai kebalikan sebuah variabel diberi tanda dengan bar yang ditulis diatas variabel tersebut. Sebagai contoh variabel $\mathrm{A}$ nilai kebalikannya adalah $\overline{\mathrm{A}}$, sehingga apabila nilai $\mathrm{A}=1$ nilai kebalikannya $\overline{\mathrm{A}}=0$. Variabel $\overline{\mathrm{A}}$ dibaca dengan A not atau A bar. Berikut adalah hukum-hukum yang digunakan pada aljabar bolean.

- Commutative Laws

1. $\mathrm{A}+\mathrm{B}=\mathrm{B}+\mathrm{A}$ 
Aljabar bolean diatas apabila diilustrasikan menggunakan gerbang logika, yaitu dengan menggunakan gerbang logika OR. Berikut aplikasi dari aljabar bolean diatas.

2. $\mathrm{A} \cdot \mathrm{B}=\mathrm{B} . \mathrm{A}$

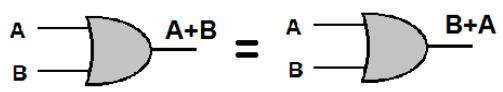

Aljabar bolean diatas apabila diilustrasikan menggunakan gerbang logika, yaitu dengan menggunakan gerbang logika AND. Berikut aplikasi dari aljabar bolean diatas.

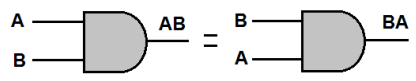

- Associative Laws

1. $\mathrm{A}+(\mathrm{B}+\mathrm{C})=(\mathrm{A}+\mathrm{B})+\mathrm{C}$

Aljabar bolen diatas apabila diilustrasikan menggunakan gerbang logika, yaitu dengan menggunakan dua buah gerbang logika OR. Berikut aplikasi dari aljabr bolean diatas.

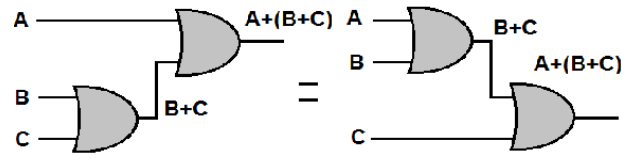

2. $\mathrm{A}(\mathrm{BC})=(\mathrm{AB}) \mathrm{C}$

Aljabar bolen diatas apabila diilustrasikan menggunakan gerbang logika, yaitu dengan menggunakan dua buah gerbang logika AND. Berikut aplikasi dari aljabr bolean diatas.
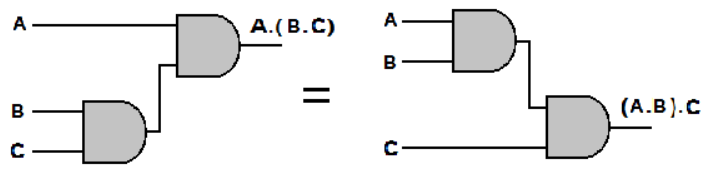

- Distributive Law

$\mathrm{A}(\mathrm{B}+\mathrm{C})=\mathrm{AB}+\mathrm{AC}$

Aljabar bolean diatas apabil diilustrasikan menggunakan gerbang logika memiliki perbedaan dimana gerbang logika yang digunakan pada $\mathrm{X}=\mathrm{A}(\mathrm{B}+\mathrm{C})$ adalah gerbang logika OR dan AND masingmasing 1 buah, sedangkan pada $\mathrm{X}=\mathrm{AB}+\mathrm{AC}$ adalah gerbang logika AND dua buah dan gerbang logika OR satu buah. Berikut aplikasi dari aljabar bolean diatas.
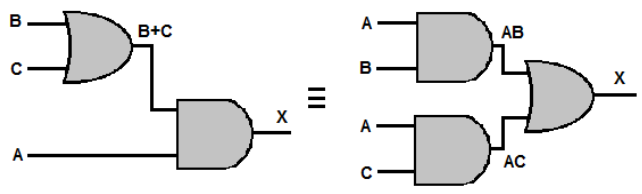
Berikut adalah ketentuan - ketentuan dasar dalam aljabar bolean.

IC gerbang logika didalamnya terdapat empat buah gerbang logika yang dapat digunakan secara sendiri-sendiri atau digabung menjadi sebuah rangkaian, bahkan dapat dibuat sebuah rangkaian dari beberapa IC gerbang logika yang berbeda jenisnya. Untuk menganalisa atau memvalidasi output sebuah rangkaian yang dibuat dapat menggunakan software Simulink Matlab. Berikut langkah- langkah membuat gerbang logika pada Simulink.

1. Buka program Matlab dengan memilih icon berikut, akan mucul tampilan Home dari Matlab dan Command Windows.

2. Pada tampilan Home pilih menu Simulink

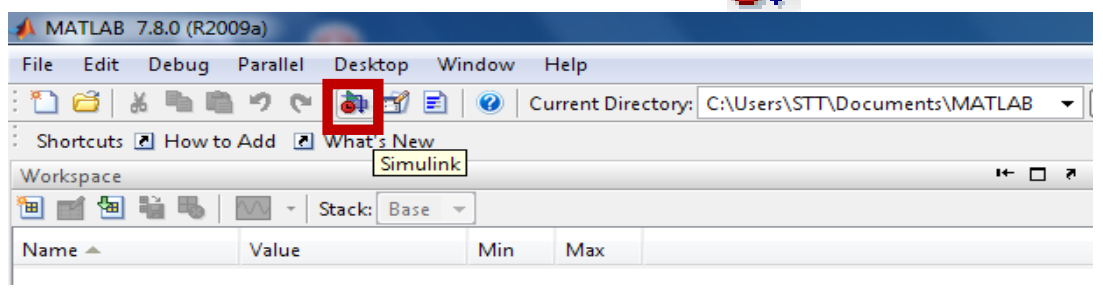

7.4. Toolbar Simulink

3. Apabila menu simulink dipilih maka akan muncul Simulink Library Browser, kemudian pilih new model sehingga akan mucul tampilan window dengan nama untitled.

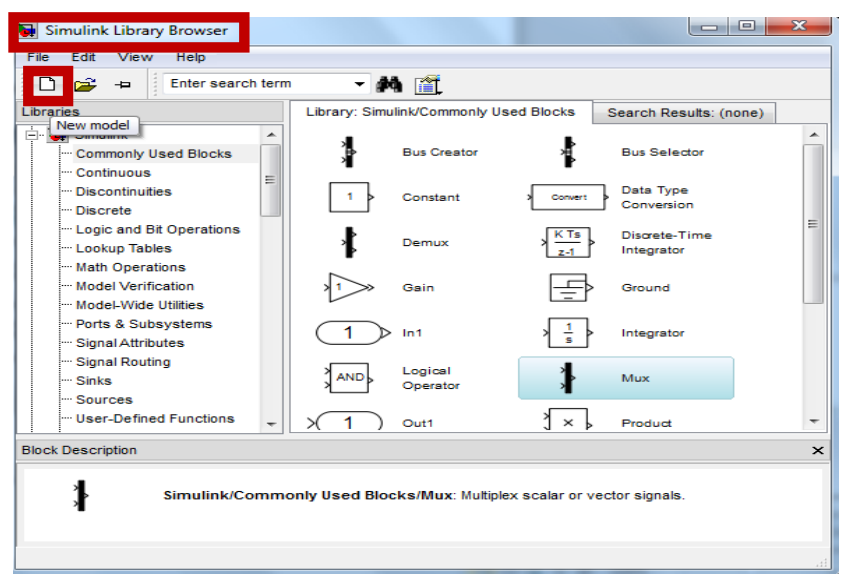

7.5. Simulink Library browser 
76 Pengantar Praktikum Mekatronika Tekstil

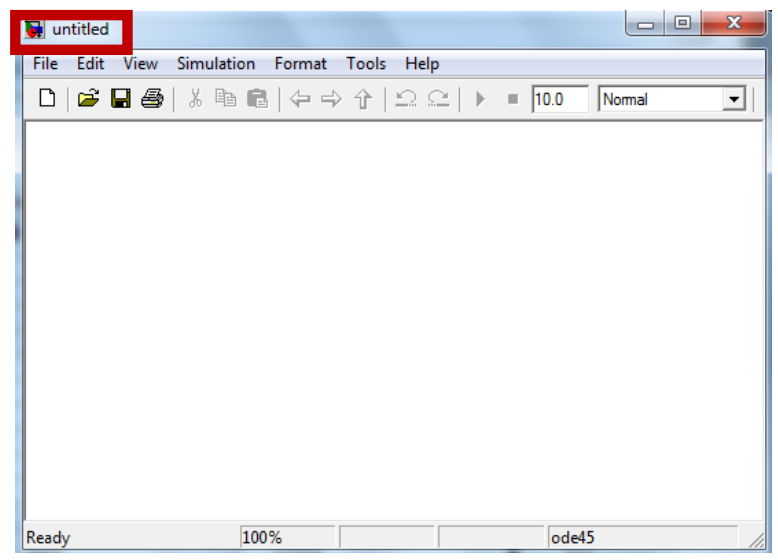

7.6. Tampilan area untuk membuat rangkaian

4. Tampilan new window untitled berfungsi sebagai media pembuatan simulasi, dalam pembuatan blok simulasi gerbang logika digunakan beberapa block description, yaitu :

- Constant (Simulink/Commonly Used Blocks/Constant) 1

- Logical Operator (Simulink/Commonly Used Blocks/Logical Operator)

- $\quad$ Display (Simulink/Sinks/Display)

5. Dalam menyusun block description dilakukan dengan cara drag simbol block description yang dipilih dan masukkan pada new window untitled. Sedangkan untuk menghubungkan diantara block description dilakukan dengan meletakkan kursor pada block description hingga kursor berubah menjadi tanda + kemudian drag menuju block description yang dituju (apabila garis penghubung antar block description berwarna hitam maka rangakain sudah benar akan tetapi jika garis penghubung berwarna merah maka rangkaian belum tepat pada titik hubungnya ).

Berikut contoh- contoh block description simulasi gerbang logika. 


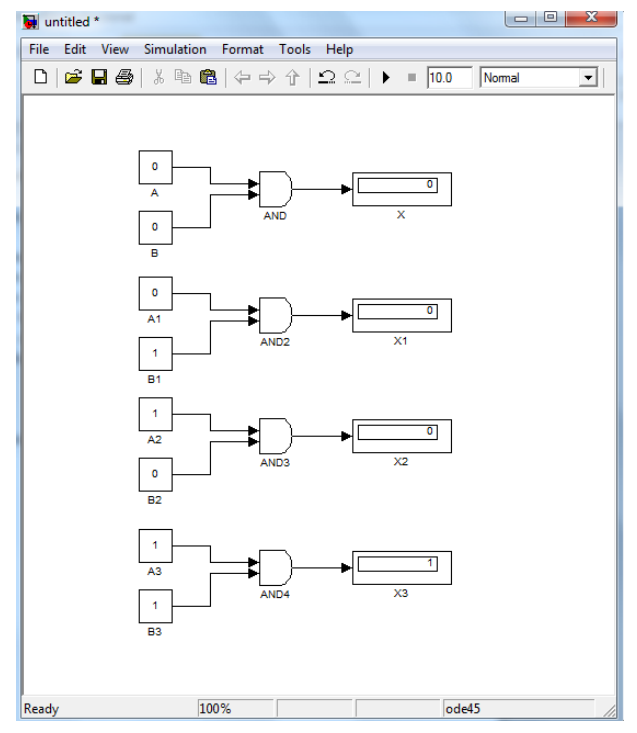

7.7. Block description 1 gerbang logika

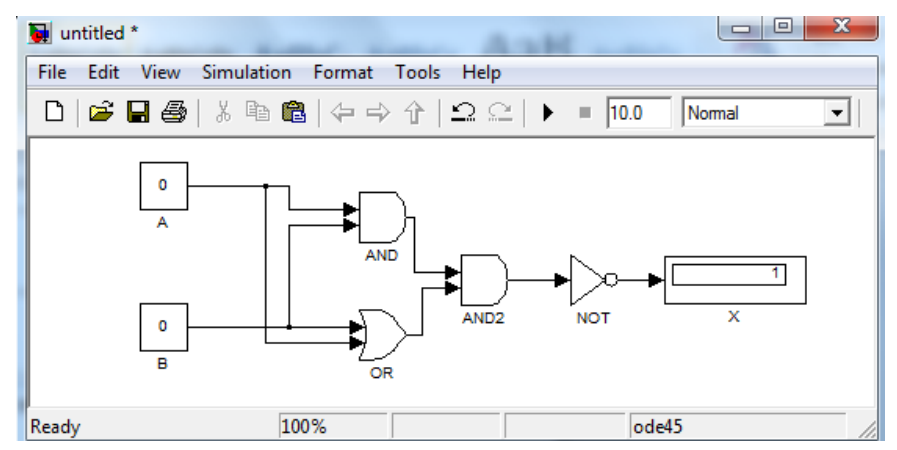

7.8. Block description 3 jenis gerbang logika

\subsection{METODE EKSPERIMEN}

Pada metode eksperimen akan dijabarkan bagaimana metode yang digunakan serta alat dan bahan yang dipakai dalam eksperimen ini.

\section{Alat dan Bahan}

Alat yang digunakan pada eksperimen ini adalah :

- Multimeter

- Project board

Bahan yang digunakan pada eksperimen ini adalah : 
78 Pengantar Praktikum Mekatronika Tekstil

- IC Gerbang logika

- Lampu LED

- Kabel Penghubung

\section{Skema Percobaan}

Menganalisa apakah tipe IC Digital yang digunakan kemudian membuat rangkaian gabungan dari beberapa Gerbang logika dan menganalisa outputnya (Gambar 7.9):
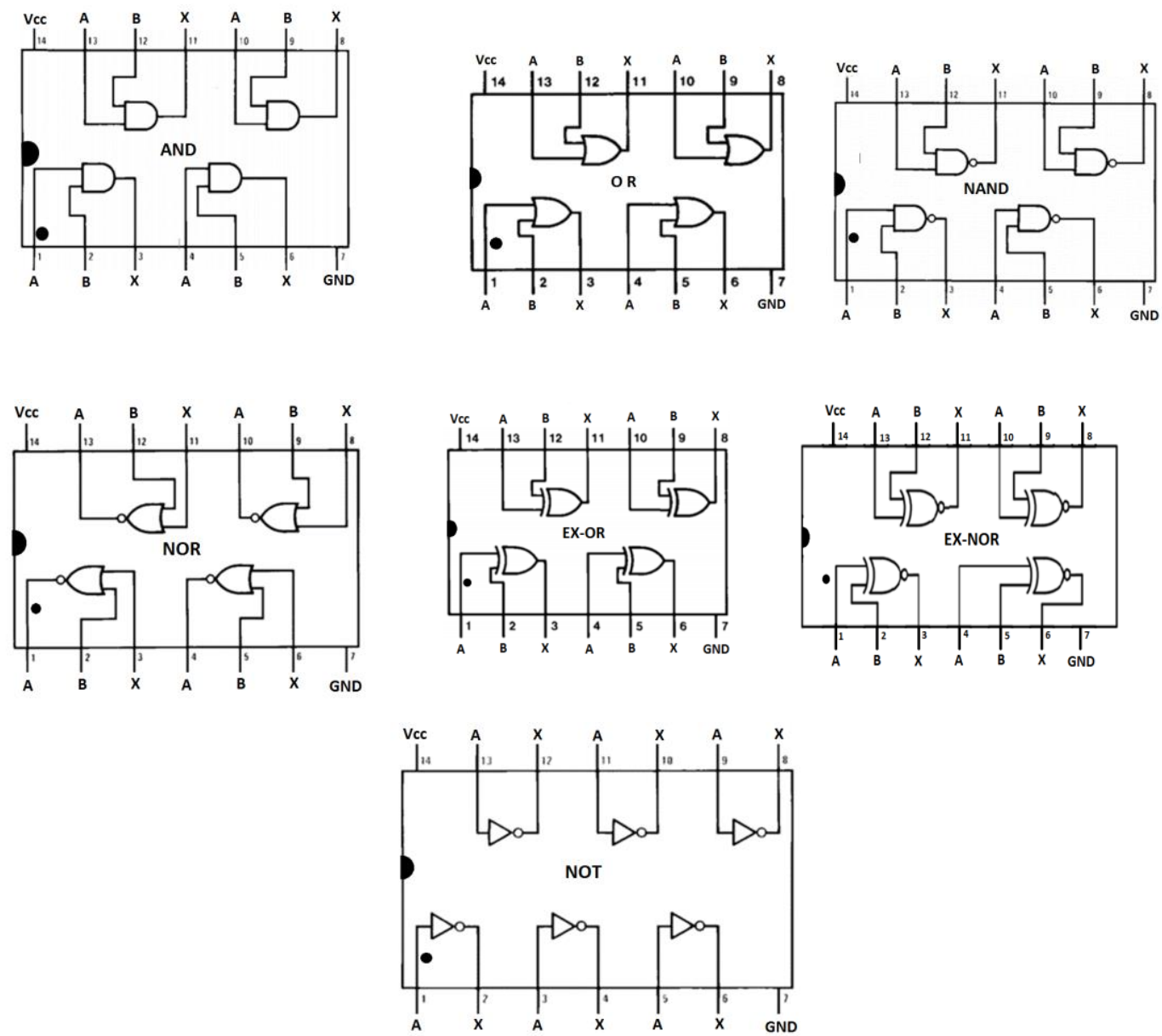

7.9. Wiring IC Gerbang Logika

\section{Cara Kerja}


- Menhunbungkan IC dengan sumber DC 5V kemudian menganalisa jenis gerbang logika didalamnya (Gambar 7.10).

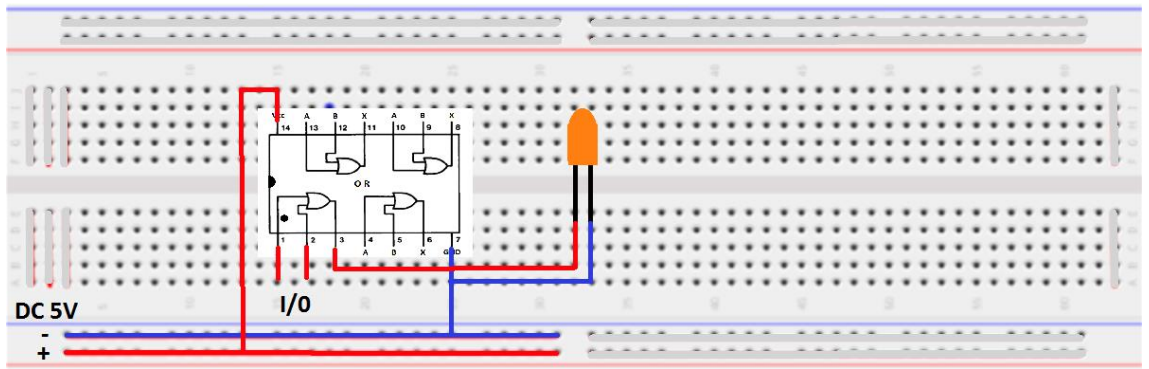

7.10. Wiring diagram rangkaian 1 gerbang logika

- Membuat rangkaian dengan beberapa gerbang logika (Gambar 7.11).

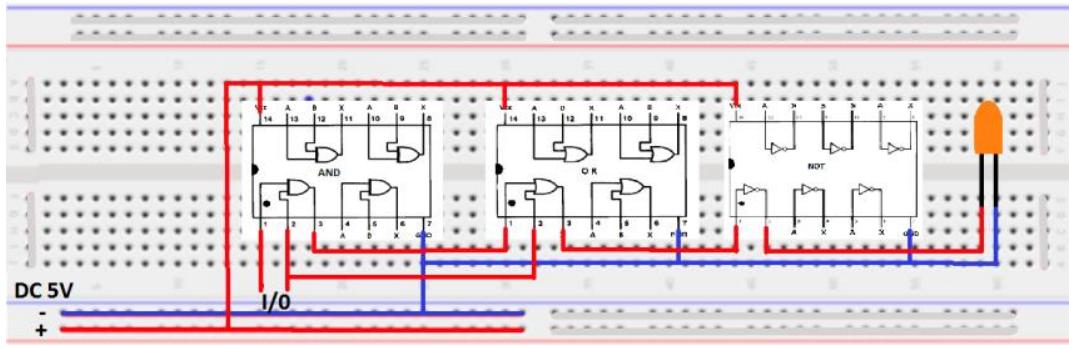

7.11. Wiring diagram rangkaian 3 jenis gerbang logika

- Membuat tabel kebenaran dari rangkaian yang dibuat.

- Memvalidasi hasil dari tabel kebenaran dengan software Simulink Matlab.

\subsection{HASIL DAN PEMBAHASAN (CONTOH HASIL EKSPERIMEN)}

- Hasil Rangkaian dari 3 IC (AND, OR dan NOT)

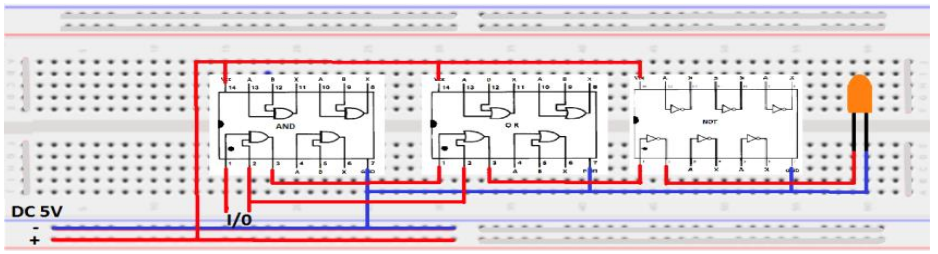

7.12. Wiring diagram rangkaian 3 jenis gerbang logika 
- Tabel kebenaran (didapat dari hasil percobaan)

Tabel 7.1 Tabel kebenaran rangkaian IC

\begin{tabular}{|c|c|c|}
\hline $\mathrm{A}$ & $\mathrm{B}$ & $\mathrm{X}$ \\
\hline 0 & 0 & 1 \\
\hline 0 & 1 & 0 \\
\hline 1 & 0 & 1 \\
\hline 1 & 1 & 0 \\
\hline
\end{tabular}

- Validasi dengan simulink Matlab seperti pada Gambar 7.13
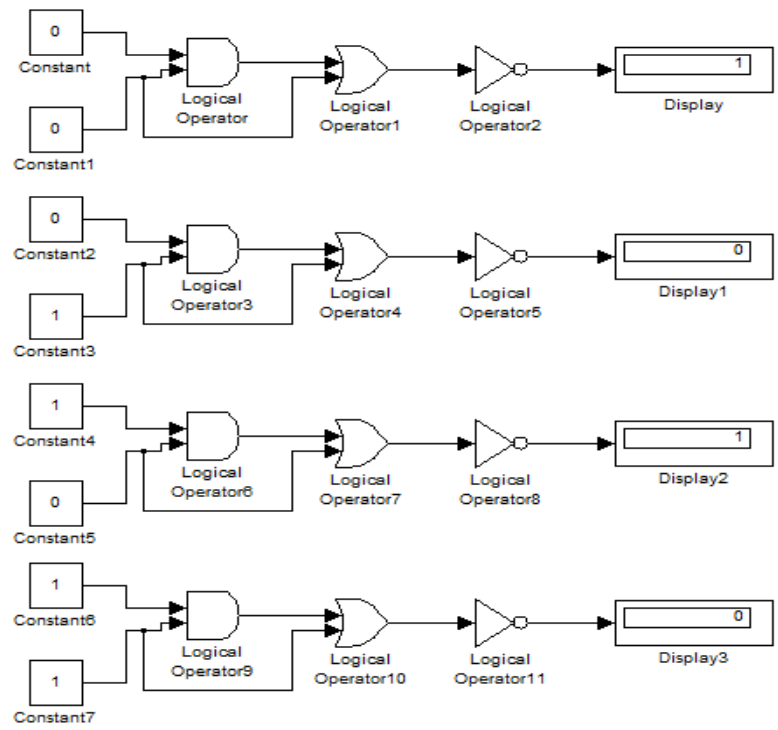

7.13. Validasi rangkaian 3 jenis gerbang logika dengan simulink

\section{KESIMPULAN DAN SARAN}

\section{Kesimpulan}

Telah dipelajari logika pemrograman sederhana dengan menggunakan IC Digital dan mengembangkan dengan menggabungkan tiga buah IC sehingga didapatkan logika tertentu sesuai dengan hasil pada tabel kebenaran. Kemudian hasil dari percobaan divalidasi dengan menggunakan software simulink Matlab dan didapatkan kesesuaian antara hasil dari percobaan dengan software simulink Matlab.

\section{Saran}


Dapat dilakukan percobaan dengan beberapa IC untuk menghasilkan logika output yang dapat digunakan sebagai indikator atau kode dari suatu kondisi tertentu.

\section{Referensi}

[1] Kana A.F., Digital Logic Design

[2] Sarjono Bambang, Rangkaian Listrik, Semarang, 2004

[3] EATON, Switch Training Manual, USA 


\title{
8
}

\section{Penyearah Gelombang (DIODE)}

Dr. Valentinus Galih V.P., S.Si.,M.Sc, Endah Purnomosari, S.T., Ngadiyono, S.T., Politeknik STTT Bandung, Indonesia

\begin{abstract}
Abstrak : Pada bab ini akan dibahas mengenai fungsi diode sebagai penyearah gelombang (rectifier) yang dapat mengubah sinyal tegangan AC (alternating current) menjadi sinyal tegangan DC (direct current). Pada eksperimen ini mencakup 2 Penyearah gelombang baik itu penyearah setengah gelombang maupun penyearah gelombang penuh. Tujuan dari eksperimen ini adalah praktikan mempunyai kemampuan merangkai dan memahami fungsi diode sebagai rectifier.
\end{abstract}

Kata kunci : diode, penyearah gelombang (rectifier), AC, DC.

\subsection{PENDAHULUAN}

Sebagian besar peralatan elektronika memerlukan sumber tegangan searah atau driff current atau biasa disebut direct current (DC). Salah satu piranti untuk mengubah tegangan AC (alternating current) adalah adaptor yang komponen utamanya adalah diode yang juga dikenal sebagai penyearah yang mengubah sumber tegangan AC menjadi tegangan DC. Diode adalah salah satu piranti listrik yang digunakan dalam beberapa peralatan listrik. Diode umumnya terbuat dari bahan semikonduktor dan secara umum biasanya terbuat dari silikon atau germanium. Aplikasi diode salah satunya pada LED (Light Emitting Diode). Penggunaan material semikonduktor dalam kehidupan seharihari adalah pada transistor, diode lampu LED dan penyearah gelombang (diode). Diode dalam rangkaian elektronika berfungsi sebagai penyearah (rectifier).

\subsection{DASAR TEORI}

\subsubsection{DIODA}

Dioda merupakan komponen elektronika yang struktur dasarnya berupa bahan semikonduktor tipe $\mathrm{P}$ yang disambungkan dengan bahan tipe $\mathrm{N}$. Pada ujung tipe $\mathrm{P}$ dijadikan sebagai terminal Anaoda (A) dan pada ujung tipe $\mathrm{N}$ dijadikan 
sebagai terminal Katoda (K). Simbol diode penyearah adalah sebagai berikut (Gambar 8.1) :

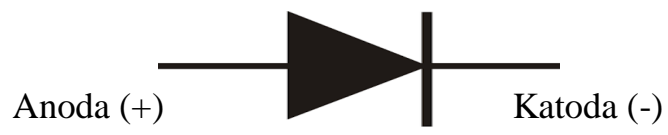

8.1 Penyearah Gelombang

Pada saat kaki anoda diode dialiri arus positif maka diode dalam posisi forward bias/bias maju sehingga arus akan mengalir ke beban. Sedangkan apabila kaki anoda diode dialiri arus negatif maka diode dalam posisi reverse bias/ bias mundur sehingga arus tidak dapat mengalir ke beban.

\subsubsection{PENYEARAH SETENGAH GELOMBANG (HALF WAVE RECTIFIER)}

Penyearah setengah gelombang merupakan penyearah yang paling sederhana, karena hanya menggunakan sebuah diode sebagai komponen utamanya. Rangkaian penyearah setengah gelombang mendapat masukan dari sekunder trafo yang berupa sinyal AC yang berbentuk sinus, $v_{i}=v_{m}$ Sin $(\omega t)$.yangmana $v_{m}$ merupakan tegangan puncak atau tegangan maksimum yang hanya bisa diukur menggunakan osiloskop dengan melihat langsung tampilan gelombang yang keluar pada layar osiloskop, sedangkan pada umumnya tegangan yang tercantum pada sekunder trafo adalah tegangan effektif. Hubungan antara tegangan $v_{m}$ dan tegangan effektif $\left(V_{e f f}\right)$ atau disebut juga sebagai tegangan rms $\left(V_{r m s}\right)$ adalah sebagai berikut :

$$
V_{\text {eff }}=V_{r m s}=\frac{V_{m}}{\sqrt{2}}=0.707 \mathrm{Vm}
$$

Tegangan effektif atau tegangan rms (root mean square) adalah tegangan yang terukur oleh voltmeter. Prinsip kerja dari penyearah setengah gelombang ini adalah pada saat sinyal input positif berupa siklus positif maka dioda dalam keadaan forward bias sehingga arus mengalir ke beban $\left(\mathrm{R}_{\mathrm{L}}\right)$. Sedangkan apabila sinyal input negatif berupa siklus negatif maka dioda dalam posisi reverse bias (diode mendapat bias mundur), sehingga arus listrik tidak dapat mengalir ke beban $\left(\mathrm{R}_{\mathrm{L}}\right)$. . Arus tertahan atau tidak dilewatkan seperti terlihat pada gambar sinyal output penyearah setengah gelombang berikut (Gambar 8.2): 

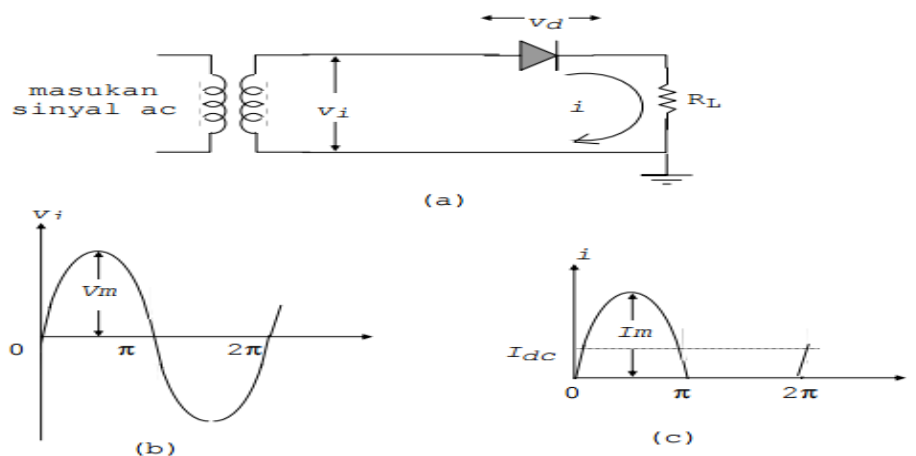

(c)

8.2. (a)Rangkaian penyearah setengah gelombang ; (b)Tegangan skunder trafo dan (c) arus beban

Arus diode yang mengalir melalui beban $R_{L}$ dinyatakan dengan :

$$
\begin{aligned}
& \mathrm{i}=\operatorname{Im} \operatorname{Sin} \omega \mathrm{t} \quad, \text { jika } 0 \leq \omega \mathrm{t} \leq \pi \quad \text { (siklus positif) } \\
& \mathrm{i}=\operatorname{Im} \operatorname{Sin} \omega \mathrm{t} \quad, \text { jika } \pi \leq \omega \mathrm{t} \leq 2 \pi \text { (siklus negatif) }
\end{aligned}
$$

dengan besar arus $I_{m}$ dapat dirumuskan sebagai berikut

$$
I_{m}=\frac{v_{m}}{R_{f}+R_{L}}
$$

Sinyal keluaran yang keluar pada osiloskop masih berbentuk gelombang, yang arah gelombangnya sama yaitu positif. sehingga harga rata-rata tidak lagi nol seperti arus bolak-balik, namun ada harga tertentu. Arus rata-rata $\left(I_{d c}\right)$ dinyatakan dengan :

$$
\begin{aligned}
& I_{d c}=\frac{1}{2 \pi} \int_{0}^{\pi} I_{m} \operatorname{Sin}(\omega \mathrm{t}) \mathrm{dt} \\
& I_{d c}=\frac{I_{m}}{\pi} \cong 0.318 \mathrm{Im}
\end{aligned}
$$

Tegangan keluaran dc adalah :

$$
v_{d c}=I_{d c} \cdot R_{L}
$$




$$
v_{d c}=\frac{I_{m} \cdot R_{L}}{\pi}
$$

Jika harga $R_{f}$ lebih kecil dari $R_{L}$, maka $R_{f}$ bisa diabaikan, sehingga $v_{m}=$ $I_{m} \cdot R_{L}$, sehingga $v_{d c}=\frac{v_{m}}{\pi} \cong 0.318 v_{m}$

\subsubsection{PENYEARAH DIODA GELOMBANG PENUH}

Penyearah gelombangpenuhterdiri dari 2 macam yaitu, dengan menggunakan trafo CT (center tap : tap tengah) dan dengan sistem jembatan 4 dioda dengan menggunakan trafo non $-\mathrm{CT}$.

a. Penyearah gelombang penuh menggunakan trafo CT (Gambar 8.3)

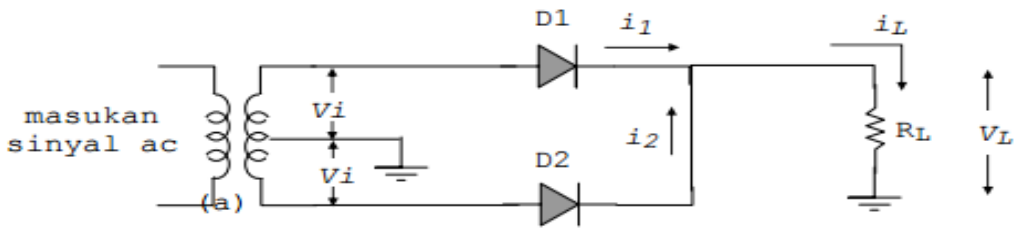

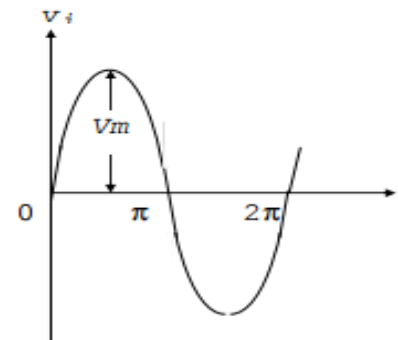

(b)
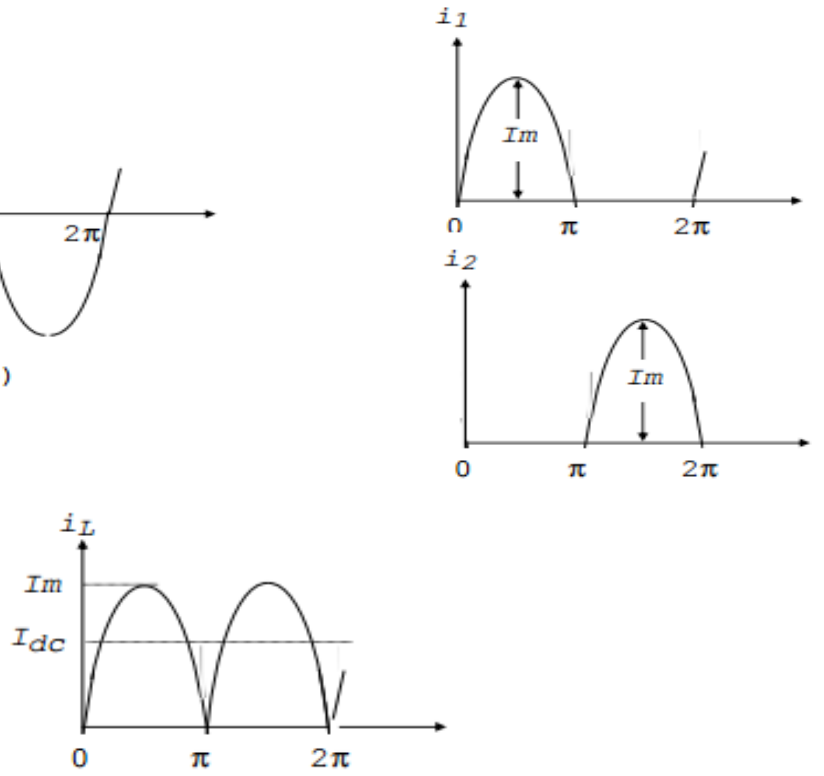

(c)

8.3. (a) Rangkaian penyearah gelombang penuh dengan trafo CT; (b) sinyal input ;

(c) arus diode dan arus beban 


\section{Pengantar Praktikum Mekatronika Tekstil}

Prinsip kerja penyearah gelombang penuh dengan trafo CT sebagai berikut, trafo CT mengeluarkan dua buah tegangan keluaran tetapi fasanya berlawanan dan titik CT sebagai titik tengahnya merupakan tegangan nol. Dioda pertama D1 dan diode kedua D2 mendapatkan keluaran trafo CT, dimana D1 mendapatkan sinyal siklus positif dan D2 mendapatkan sinyal siklus negatif. Rangkaian penyearah gelombang penuh dengan trafo CT merupakan gabungan dari dua penyearah setengah gelombang yang bekerjanya bergantian apabila mendapatkan siklus sinyal positif. Sehingga arus dc diperoleh sebagai berikut :

$$
I_{d c}=\frac{2 I_{m}}{\pi} \cong 0.636 I_{m}
$$

dan

$$
v_{d c}=\frac{2 v_{m}}{\pi} \cong 0.636 v_{m}
$$

b. Penyearah Gelombang Penuh sistem jembatan (Gambar 8.4)

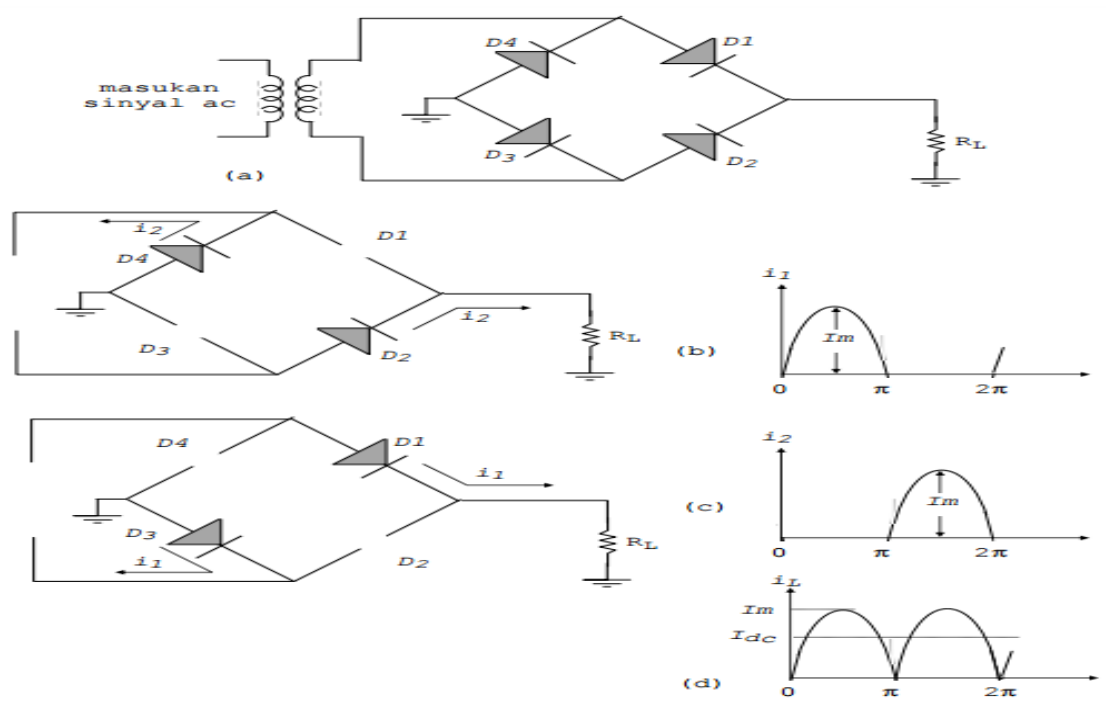

8.4. (a) Rangkaian penyearah gelombang penuh sistem jembatan; (b) saat siklus positif; (c) saat siklus negatif; (d) arus beban

Prinsip kerja penyarah gelombang penuh sistem jembatan adalah pada saat diode D1 mendapatkan siklus sinyal positif maka akan mengalami forward 
bias, sedangkan D2 dan D4 mengalami reverse bias dan mengakibatkan arus mengalir dari D1 ke beban $\left(R_{L}\right)$ kemudian melalui D3 dan kembali pada sisi yang lain. Apabila D2 mendapatkan siklus sinyal positif maka akan mengalami forward bias, sedangkan D1 dan D3 mengalami reverse bias. Sehingga arus mengalir dari D2 ke beban $\left(R_{L}\right)$ kemudian melalui D4 dan kembali pada sisi yang lain, sehingga membentuk sinyal gelombang penuh. Untuk arus dc dan tegangan dc yang keluar pada penyarah gelombang penuh sistem jembatan sama dengan penyearah gelombang penuh dengan trafo CT, yaitu:

$$
I_{d c}=\frac{2 I_{m}}{\pi} \cong 0.636 I_{m}
$$

dan

$$
v_{d c}=\frac{2 v_{m}}{\pi} \cong 0.636 v_{m}
$$

\subsection{HASIL DAN PEMBAHASAN (CONTOH HASIL ESPERIMEN)}

Pada eksperimen ini akan dijabarkan bagaimana metode yang digunakan serta alat dan bahan yang dipakai dalam eksperimen ini.

\subsubsection{Alat dan Bahan}

Alat dan bahan yang dipakai pada eksperimen ini adalah :

1. Dioda

2. Resistor

3. Sumber tegangan $(\mathrm{AC})$

4. Osiloskop

5. Kabel penghubung

6. Papan rangkaian (Project Board)

\subsubsection{Skema Percobaan}

Dapat diperlihatkan skema percobaan eksperimen ini seperti pada Gambar 8.5 hingga Gambar 8.7 di bawah 
88 Pengantar Praktikum Mekatronika Tekstil
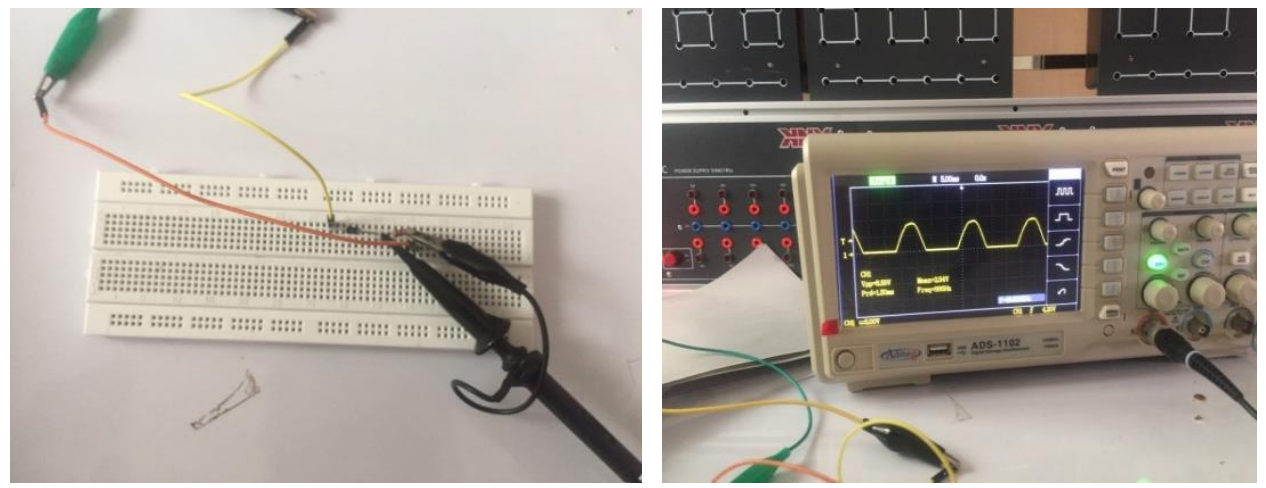

8.5 Percobaan penyearah setengah gelombang
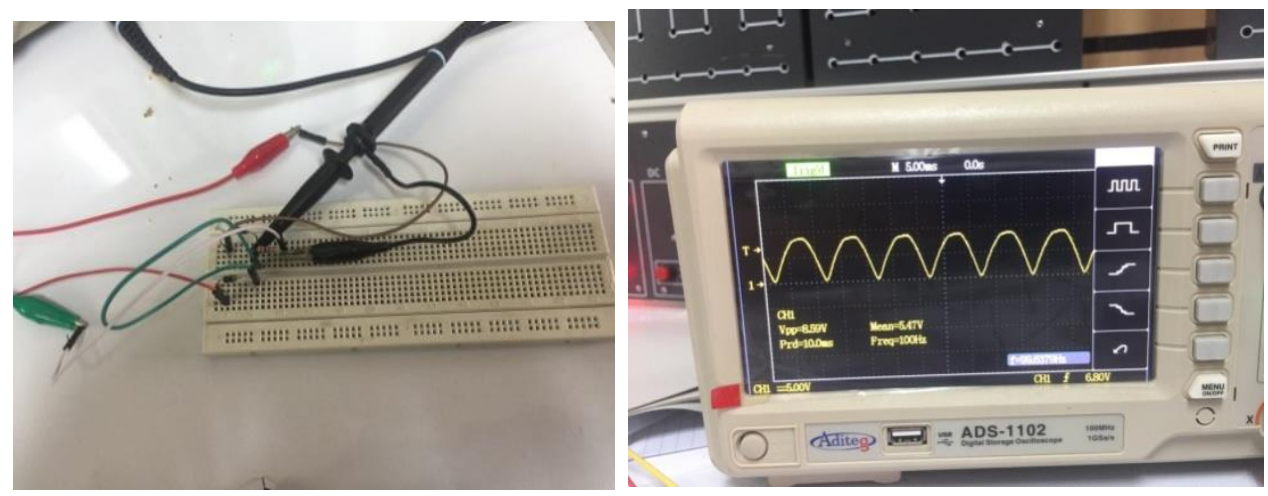

8.6 Percobaan penyearah gelombang penuh dengan trafo CT
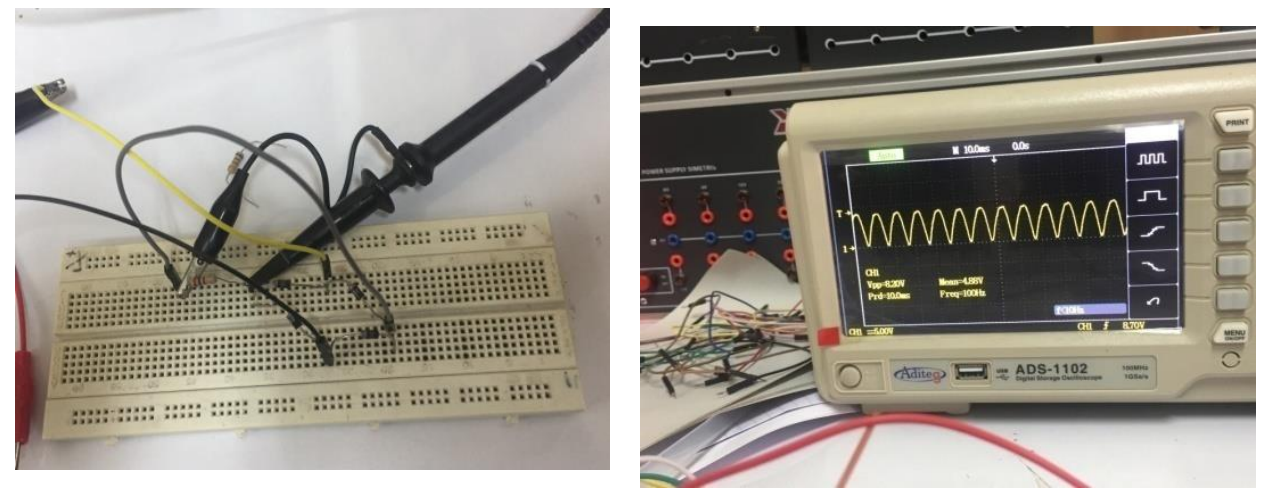

8.7 Percobaan penyearah gelombang penuh sistem jembatan 


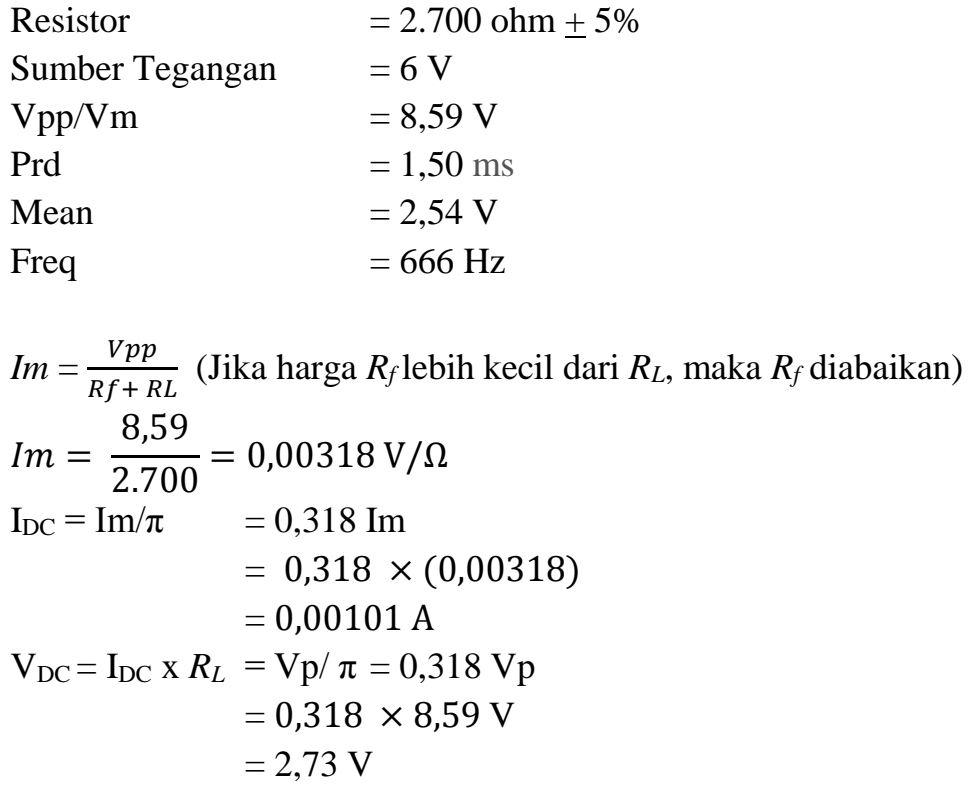

2. Penyearah Gelombang Penuh dengan 2 Dioda

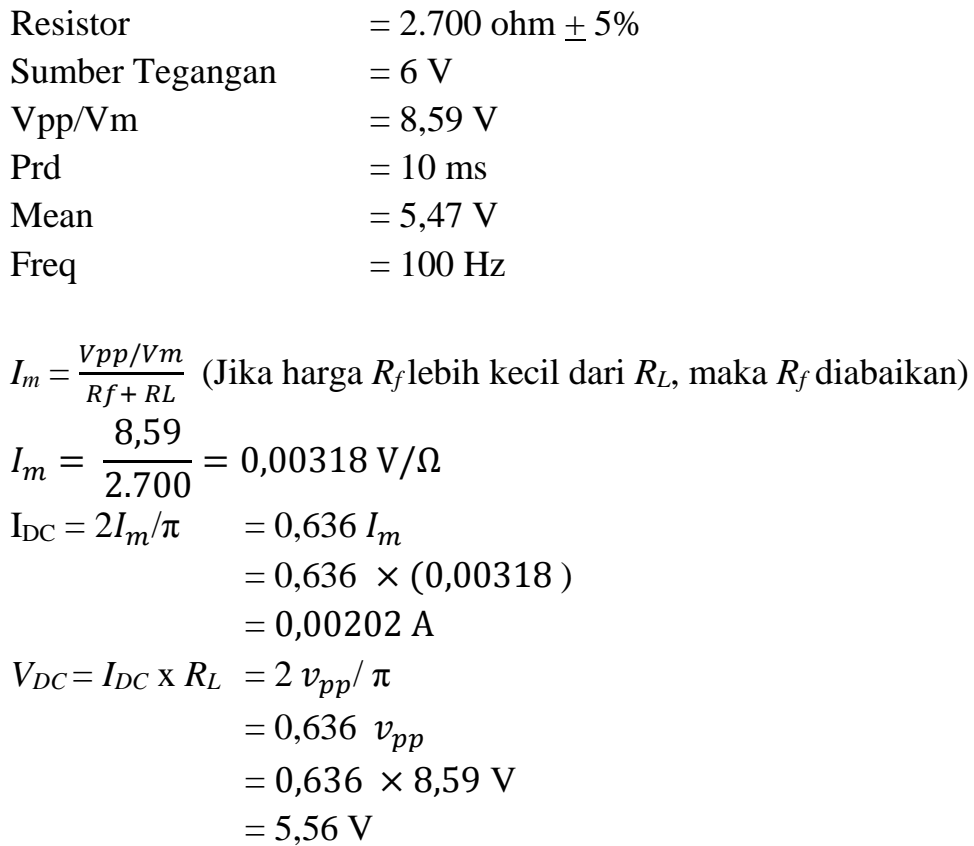

\section{Penyearah Gelombang Penuh dengan 4 Dioda}




$$
\begin{aligned}
& \text { Resistor } \\
& =2.700 \mathrm{ohm}+5 \% \\
& \text { Sumber Tegangan } \quad=6 \mathrm{~V} \\
& \mathrm{Vpp} / \mathrm{Vm} \quad=8,20 \mathrm{~V} \\
& \text { Prd } \quad=10 \mathrm{~ms} \\
& \text { Mean } \quad=4,88 \mathrm{~V} \\
& \text { Freq } \quad=100 \mathrm{~Hz} \\
& I_{m}=\frac{V p p / V m}{R f+R L}(\text { Jika harga Rf lebih kecil dari RL diabaikan) } \\
& \operatorname{Ip} / \operatorname{Im}=\frac{8,20}{2700}=0,00303 \mathrm{~V} / \Omega \\
& \mathrm{I}_{\mathrm{DC}}=4 I_{m} / \pi \quad=1,272 I_{m} \\
& =1,272 \times(0,00303) \\
& =0,0038 \mathrm{~A} \\
& \mathrm{~V}_{\mathrm{DC}}=\mathrm{I}_{\mathrm{DC}} \times \mathrm{R}_{\mathrm{L}}=2 \mathrm{Vpp} / \pi \\
& =0,636 \mathrm{Vpp} \\
& =0,636 \times 8,20 \mathrm{~V} \\
& =5,21 \mathrm{~V}
\end{aligned}
$$

\begin{tabular}{|c|c|c|c|}
\hline Keterangan & $\begin{array}{l}\text { Penyearah } \\
\text { gelombang }\end{array}$ & $\begin{array}{l}\text { Penyearah gelombang } \\
\text { penuh dengan trafo }\end{array}$ & $\begin{array}{l}\text { Penyearah } \\
\text { gelombang } \\
\text { penuh sistem } \\
\text { jembatan }\end{array}$ \\
\hline $\begin{array}{l}\text { Hasil } \\
\text { eksperimen }\end{array}$ & Mean $/ \mathrm{Vdc}=2,54 \mathrm{~V}$ & Mean/Vdc $=5,47 \mathrm{~V}$ & $\begin{array}{l}\text { Mean/Vdc= } \\
4,88 \mathrm{~V}\end{array}$ \\
\hline Hasil teori & $\begin{array}{l}\mathrm{I}_{\mathrm{DC}}=0,00101 \mathrm{~A} \\
\mathrm{~V}_{\mathrm{DC}}=2,73 \mathrm{~V}\end{array}$ & $\begin{array}{l}\mathrm{I}_{\mathrm{DC}}=0,00202 \mathrm{~A} \\
\mathrm{~V}_{\mathrm{DC}}=5,56 \mathrm{~V}\end{array}$ & $\begin{array}{l}\mathrm{I}_{\mathrm{DC}}=0,0038 \mathrm{~A} \\
\mathrm{~V}_{\mathrm{DC}}=5,21 \mathrm{~V}\end{array}$ \\
\hline
\end{tabular}

\section{KESIMPULAN DAN SARAN}

Pada eksperimen ini telah dipelajari fungsi diode sebagai penyearah gelombang baik itu penyearah setengah gelombang maupun penyearah gelombang penuh. Hasil eksperimen dengan hasil teori dapat dilihat sebagai berikut :

Tabel 8.1 hasil 1 eksperimen penyearah gelombang

\section{Referensi}


[1] Halliday, D., Resnick, R., Walker, Fundamenthal of Physics-Extended, $5^{\text {th }}$, John Wiley \& Sons, New York 1997.

[2] Putra, V.G.V, Endah dan Ngadiono, Pengantar Listrik Magnet dan Terapannya, Penerbit CV. Mulia Jaya, Yogyakarta, 2016.

[3] Suarga, Fisika Komputasi Solusi Problema Fisika dengan Matlab, Penerbit Andi, Yogyakarta, 2005.

[4] Surjono, H.D., Elektronika Teori dan Penerapan, Cerdas Ulet Kreatif, Jember, 2011

[5] Wijaya, S.K., Diktat Elektronika I, Fisika FMIPA UI. 


\title{
9
}

HUKUM KIRCHOFF

Dr. Valentinus Galih V.P., S.Si.,M.Sc, Endah Purnomosari, S.T., Ngadiyono, S.T., Politeknik STTT Bandung, Indonesia

\begin{abstract}
Abstrak :Pada eksperimen ini akan diberikan salah satu topik Hukum Kirchoff untuk menganalisia arus dan tegangan listrik. Praktikum Hukum Kirchhoff ini ditujukan untuk memverifikasi teori Hukum Kirchhoff melalui eksperimen dengan validasi secara teori dan matlab. Terdapat dua buah Hukum Kirchhoff yang akan diverifikasi, yaitu Hukum Kirchhoff Pertama yang dikenal juga sebagai Hukum Arus Kirchhoff (HAK) yang merupakan hukum yang mengatur kelestarian arus listrik yang melewati jalur percabangan, yaitu besar arus yang memasuki titik percabangan harus sama dengan besar arus yang meninggalkan titik percabangan, sedangkan Hukum Kirchhoff Kedua yang dikenal juga sebagai Hukum Tegangan Kirchhoff (HTK ) yang merupakan hukum yang menyatakan bahwa, jumlahan voltase pada suatu rangkaian loop tertutup haruslah sama dengan nol.
\end{abstract}

Kata Kunci : Hukum Kirchoff Pertama (HAK), Hukum Kirchoff Kedua (HTK)

\subsection{PENDAHULUAN}

Dalam kehidupan sehari-hari penerapan Hukum Kirchoff dapat ditemui pada piranti peralatan listrik. seperti lampu, televisi dan sebagainya. Di dalam menyalakan lampu, terdapat satu saklar yang bisa menyalakan beberapa lampu dan mematikan beberapa lampu. berdasarkan fenomena di atas, maka dapat diektahui bahwa ada lampu yang dirangkai seri dan juga ada lampu yang dirangkai sejajar atau parallel. Dalam merangkai rangkaian seri maupun parallel sebaiknya pengetahuan mengenai besar arus dan tegangan yang masuk ke tiap-tiap lampu dapat dipahami dengan baikmelalui pemahaman ytang baik mengenai hukum ohm dan hukum kirchoff.

Pada praktikum hukum kirchoff, akan di bagi menjadi 3 rangkaian listrik, yaitu rangkaian seri, rangkaian parallel dan rangkaian gabungan (seri- parallel). Di dalam tiap rangkaian tersebut praktikan diharuskan mencari arus dan tegangan masing-masing resistor. Setelah didapatkan hasil eksperimen, praktikan mensimulasikan dengan menggunakan software matlab. Hasil ekperimen dan simulasi dengan matlab akan divalidasi dengan hasil perhitungan teori. 


\subsection{DASAR TEORI}

\subsubsection{Hukum kirchoff Pertama (HAK)}

Hukum Kirchhoff Pertama merupakan Hukum Kirchhoff yang berkaitan dengan dengan arah arus dalam menghadapi titik percabangan. Hukum Kirchhoff Pertama ini sering disebut juga dengan Hukum Arus Kirchhoff (HAK) atau Kirchhoff's Current Law (KCL). Bunyi Hukum Kirchhoff Pertama adalah sebagai berikut :

"Arus Total yang masuk melalui suatu titik percabangan dalam suatu rangkaian listrik sama dengan arus total yang keluar dari titik percabangan tersebut."

Untuk lebih jelas mengenai Hukum Kicrhhoff 1, dapat dilihat rumus dan Gambar 9.1 rangkaian sederhana dibawah ini :

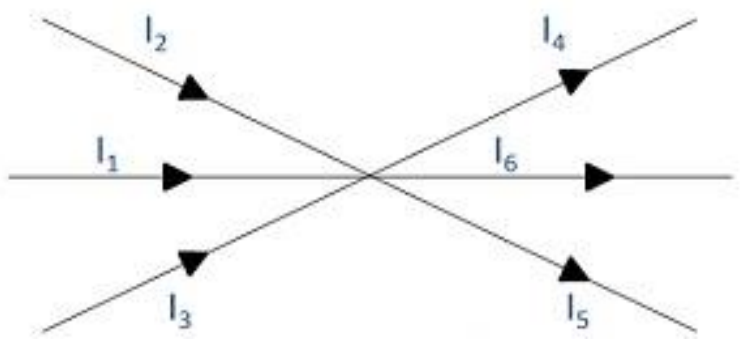

9.1 Hukum Kirchoff pertama (pembagi arus) (Jumadi,2010)

Berdasarkan Rangkaian diatas, dapat dirumuskan bahwa :

$$
I_{1}+I_{2}+I_{3}=I_{4}+I_{5}+I_{6}
$$

\subsubsection{Hukum kirchoff Kedua}

Hukum Kirchhoff 2 merupakan Hukum Kirchhoff yang digunakan untuk menganalisis tegangan (beda potensial) komponen-komponen elektronika pada suatu rangkaian tertutup. Hukum Kirchhoff 2 ini juga dikenal dengan sebutan Hukum Tegangan Kirchhoff atau Kirchhoff's Voltage Law (KVL).

Bunyi Hukum Kirchhoff 2 adalah sebagai berikut : 


\section{Pengantar Praktikum Mekatronika Tekstil}

"Total Tegangan (beda potensial) pada suatu rangkaian tertutup adalah nol"

Untuk lebih jelas mengenai Hukum Kirchhoff 2 dapat diperlihatkan pada Gambar 9.2 di bawah, dapat dirumuskan bahwa :

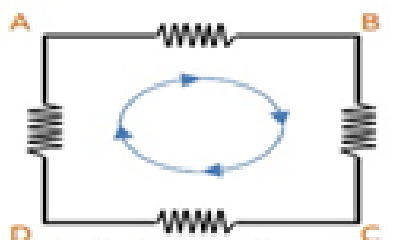

9.2 hukum Kirchoff pembagi tegangan (Jumadi,2010)

$$
\mathrm{V}_{\mathrm{ab}}+\mathrm{V}_{\mathrm{bc}}+\mathrm{V}_{\mathrm{cd}}+\mathrm{V}_{\mathrm{da}}=0
$$

\subsubsection{Resistor}

Resistor adalah suatu komponen elektronika yang fungsinya untuk menghambat arus listrik. Resistor dibagi menjadi dua, yaitu :

1. Resistor tetap

Merupakan resistor yang memiliki nilai hambatan yang tetap. Resistor tetap ini hanya dapat dioperasikan dengan kemampuan daya nya misalnya : 1/16 Watt, 1/8 Watt, 1/4 Watt, 1/2 Watt, dsb. Resistor tetap memiliki 2 jenis bentuk resistor, yaitu resistor yang memiliki 4 cincin warna dan resistor yang memiliki 5 cincin warna. Simbol dan bentuk resistor dapat dilihat pada Gambar 9.3 di bawah ini :
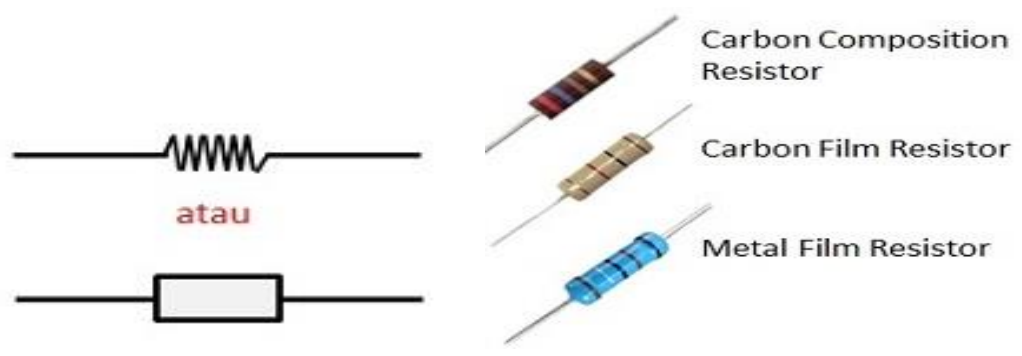

9.3 Jenis resistor (Jumadi,2010) 
Tabel 9.1 Nilai warna pada cincin resistor tetap :

\begin{tabular}{|l|c|c|c|c|c|}
\hline Warna Cincin & Cincin I & Cincin II & Cincin III & $\begin{array}{c}\text { Cincin IV } \\
\text { Pengali }\end{array}$ & $\begin{array}{c}\text { Cincin V } \\
\text { Toleransi }\end{array}$ \\
\hline Hitam & 0 & 0 & 0 & $\times 1$ & \\
\hline Coklat & 1 & 1 & 1 & $\times 10^{1}$ & $\pm 1 \%$ \\
\hline Merah & 2 & 2 & 2 & $\times 10^{2}$ & $\pm 2 \%$ \\
\hline Jingga & 3 & 3 & 3 & $\times 10^{3}$ & \\
\hline Kuning & 4 & 4 & 4 & $\times 10^{4}$ & \\
\hline Hijau & 5 & 5 & 5 & $\times 10^{5}$ & \\
\hline Biru & 6 & 6 & 6 & $\times 10^{6}$ & \\
\hline Ungu & 7 & 7 & 7 & $\times 10^{7}$ & \\
\hline Abu- abu & 8 & 8 & 8 & $\times 10^{6}$ & \\
\hline Putih & 9 & 9 & 9 & $\times 10^{9}$ & \\
\hline Emas & & & & $\times 0,1$ & $\pm 5 \%$ \\
\hline Perak & & & & $\times 0,01$ & $\pm 10 \%$ \\
\hline Tanpa warna & & & & & $\pm 20 \%$ \\
\hline
\end{tabular}

Cara membaca nilai tahanan resistor berdasarkan cincin warna pada resistor:

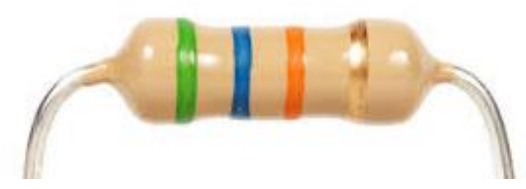

9.4 Membaca tahanan resistor (Jumadi,2010)

Cincin $1:$ hijau $=5$

Cincin $2:$ biru $=6$

Cincin $3:$ orange/jingga $=3$

Cincin $4:$ emas $=5 \%$

Jadi nilai resistor di atas : $56000 \Omega=56 \mathrm{~K} \Omega$ dengan toleransi $5 \%$, sehingga nilai maximum resistor : $56000+(5 \% * 56000)=58800 \Omega$ Nilai minimum resistor : $56000-(5 \% * 56000)=53200 \Omega$ dari keterangan diatas dapat ditarik kesimpulan bahwa nilai hambatan resistor pada gambar di atas adalah $(56 \pm 2,8) \mathrm{K} \Omega$.

\section{Resistor variabel}

Merupakan resistor yang nilai hambatannya dapat diubah-ubah. Jenis resistor variable adalah hambatan geser, potensiometer dan trimpot. 


\subsection{METODE EKSPERIMEN}

Pada metode eksperimen akan dijabarkan bagaimana metode yang digunakan serta alat dan bahan yang dipakai dalam eksperimen ini.

Alat dan Bahan

Alat dan bahan yang dipakai pada eksperimen ini adalah :

- Porject board

- Resistor

- Power supply Dc

- Osciloscope

- Komputer

- Alat tulis

Skema Percobaan

Dapat diperlihatkan skema percobaan eksperimen ini sesuai dengan rangkaian di bawah ini :

Dengan menggunakan osiloskop cari tegangan $R_{1}, R_{2}$, dan $R_{3}$ dengan melihat layar osiloskop.

\section{Rangkaian 1}

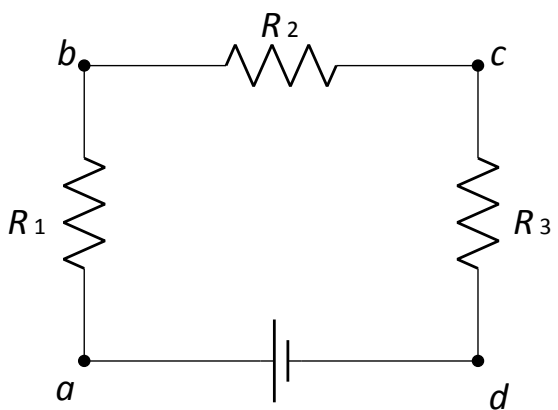

- Power suplly DC yang anda gunakan adalah... .... V

- Beda potensial $V_{a b}$ antara titik $a$ dan $b$ adalah....... V

- Beda potensial $V_{b c}$ antara titik $b$ dan $c$ adalah........ V

- Beda potensial $V_{c d}$ antara titik $c$ dan $d$ adalah......... V

- Validasi rangkaian di atas dengan aplikasi matlab yang ada di computer 


\section{Rangkaian 2}

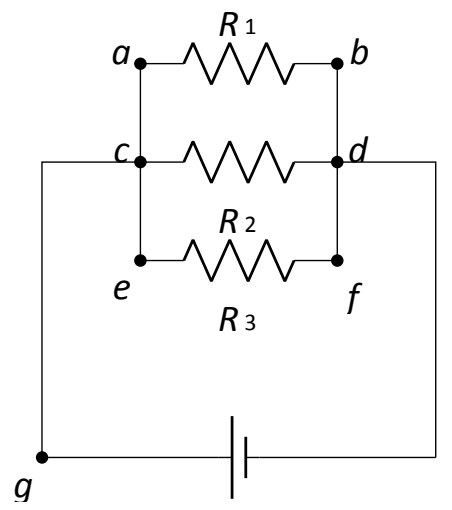

- Power suplly DC yang anda gunakan adalah... V

- Beda potensial $V_{a b}$ antara titik $a$ dan $b$ adalah... V

- Beda potensial $V_{c d}$ antara titik $c$ dan $d$ adalah... V

- Beda potensial $V_{e f}$ antara titik $e \operatorname{dan} f$ adalah...V

- Validasi rangkaian di atas dengan aplikasi matlab yang ada di computer

\section{Rangkaian 3}

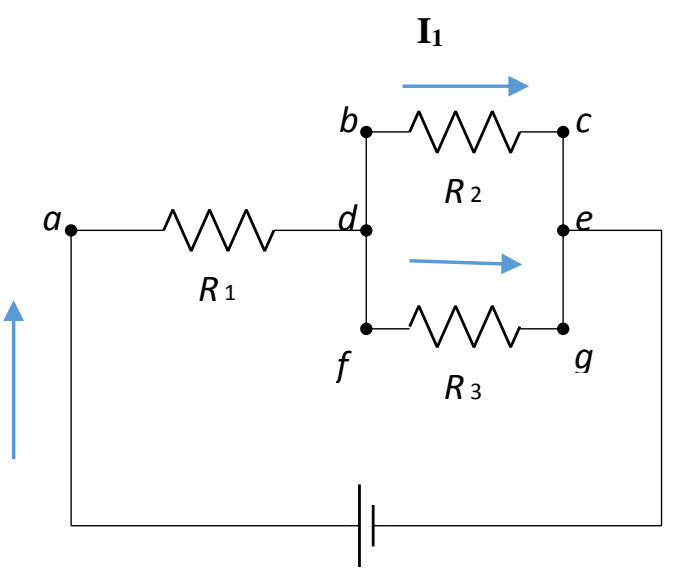

$\mathbf{I}_{2}$

- Power suplly DC yang anda gunakan adalah... V

- Beda potensial $V_{a d}$ antara titik $a$ dan $d$ adalah... V

- Beda potensial $V_{b c}$ antara titik $b$ dan $c$ adalah... V

- Beda potensial $V_{f g}$ antara titik $f$ dan $g$ adalah... V

- Validasi rangkaian di atas dengan aplikasi matlab yang ada di komputer

Dalam pengerjaan laporan, bandingkan hasil yang anda peroleh lewat praktikum ini dengan hitungan teori pada tiap rangkaian.

\section{Cara kerja :}


- Dicari 3 resistor dengan nilai tahanan yang berbeda

- Disusun resistor sesuai rangkaian di atas

- Dihubungkan resistor yang sudah disusun sesuai rangkaian di atas dengan kebel jumper yang sudah di hubungkan ke power suplly DC

- Dihubungkan kaki resistor dengan probe osiloskop untuk melihat tegangan yang masuk ke resistor

- Dicobakan untuk resistor yang lain

- Divalidasi dengan matlab

\subsection{HASIL DAN PEMBAHASAN (CONTOH HASIL EKSPERIMEN)}

Pada perhitungan tunggal di dapatkan bahwa nilai tahanan masing-masing resistor :

$$
\begin{array}{ll}
\mathrm{R}_{1}=51 \mathrm{~K} \Omega & =51000 \Omega \\
\mathrm{R}_{2}=100 \mathrm{~K} \Omega & =100000 \Omega \\
\mathrm{R}_{3}=1500 \mathrm{~K} \Omega & =1500000 \Omega
\end{array}
$$

Tegangan sumber $=12 \mathrm{~V}$

Maka arus dan tegangan masing-masing resistor di tiap rangkaian :

\section{- Rangkaian Seri}

$$
\begin{aligned}
& \begin{aligned}
\mathrm{Rs} & =\mathrm{R}_{1}+\mathrm{R}_{2}+\mathrm{R}_{3} \\
& =51+100+1500 \\
& =1651 \mathrm{~K} \Omega=1651000 \Omega
\end{aligned} \\
& \mathrm{V}=\mathrm{I} \mathrm{R} \\
& \begin{aligned}
12 & =\mathrm{I}\left(\mathrm{R}_{1}+\mathrm{R}_{2}+\mathrm{R}_{3}+\mathrm{R}_{4}\right)
\end{aligned} \\
& \begin{array}{l}
\mathrm{I} \text { total }=\frac{12}{1651000}=0,0000073 \mathrm{~A}
\end{array}
\end{aligned}
$$

Dikarenakan rangkaian seri maka $\mathrm{I}_{1}-\mathrm{I}_{4}$ bernilai sama, sehingga

$$
\begin{aligned}
& \mathrm{V}_{1}=\mathrm{IR}_{1} \\
& \quad=0,0000073 \times 51000=0,37 \mathrm{~V} \\
& \mathrm{~V}_{2}=\mathrm{IR}_{2} \\
& \quad=0,0000073 \times 100000=0,73 \mathrm{~V} \\
& \mathrm{~V}_{3}=\mathrm{IR}_{3} \\
& \quad=0,0000073 \times 1500000=10,95 \mathrm{~V}
\end{aligned}
$$

\section{- Rangkaian Paralel}




$$
\begin{aligned}
\frac{1}{R p}=\frac{1}{R 1}+\frac{1}{R 2} & +\frac{1}{R 3} \\
& =\frac{1}{51 \mathrm{~K} \Omega}+\frac{1}{100 \mathrm{~K} \Omega}+\frac{1}{1500 \mathrm{~K} \Omega} \\
& =\frac{1500+765+51}{76500} \mathrm{~K} \Omega \\
& =\frac{2316}{76500} \mathrm{~K} \Omega \\
\mathrm{Rp}=\frac{76500}{2316} \mathrm{k} \Omega & \\
= & 33,031 \mathrm{~K} \Omega=33000 \Omega
\end{aligned}
$$

Diakrenakan rangkaian adalah Paralel, maka $\mathrm{V}_{1}-\mathrm{V}_{3}$ bernilai sama

$$
\begin{aligned}
\mathrm{I}_{1} & =\frac{V}{R} \\
& =\frac{12}{51000} \\
& =0,00024 \mathrm{~A} \\
\mathrm{I}_{2} & =\frac{V}{R} \\
& =\frac{12}{100000} \\
& =0,00012 \mathrm{~A} \\
\mathrm{I}_{3} & =\frac{V}{R} \\
& =\frac{12}{1500000} \\
& =0,000008 \mathrm{~A}
\end{aligned}
$$

\section{- Rangkaian Seri-Paralel}

$$
\begin{aligned}
\mathrm{R}_{\text {seri }} & =\mathrm{R} 1 \\
& =51 \mathrm{~K} \Omega=51000 \Omega \\
R_{\text {paralel }}=\frac{1}{R 2}+\frac{1}{R 3} & \\
& =\frac{1}{100 \mathrm{~K} \Omega}+\frac{1}{1500 \mathrm{~K} \Omega} \\
& =\frac{15+1}{1500} \mathrm{~K} \Omega
\end{aligned}
$$


100 Pengantar Praktikum Mekatronika Tekstil

$$
\begin{aligned}
& \quad=\frac{16}{1500} \mathrm{~K} \Omega \\
& \mathrm{Rp} \quad=\frac{1500}{16} \mathrm{~K} \Omega \\
& =93,75 \mathrm{~K} \Omega=93750 \Omega \\
& R_{\text {total }}=R_{\text {seri }}+R_{\text {paralel }}=51000 \Omega+93750 \Omega=144750 \Omega \\
& \Sigma \mathrm{V}=0 \\
& \mathrm{IR}=0 \\
& \mathrm{I}(\mathrm{Rs}+\mathrm{Rp})=12 \\
& \mathrm{Itotal}=\frac{12}{144750}=0,000083 \mathrm{~A}
\end{aligned}
$$

Tegangan $\mathrm{R}$ seri dan $\mathrm{R}$ paralel

$$
\begin{aligned}
& \mathrm{V}_{1}=\mathrm{IR}_{\text {seri }} \\
& \quad=0,000083 \times 51000=4,23 \mathrm{~V} \\
& \mathrm{~V}_{2}=\mathrm{IR}_{\text {paralel }} \\
& \quad=0,000083 \times 93750=7,78 \mathrm{~V}
\end{aligned}
$$

Arus pada R2 dan R3 :

$$
\begin{aligned}
\mathrm{I}_{\mathrm{R} 2}: \mathrm{I} 1 & =\frac{R 3}{R 2+R 3} \text { I total } \\
& =\frac{1500 \mathrm{~K} \Omega}{100 \mathrm{~K} \Omega+1500 \mathrm{~K} \Omega} 0,000083 \\
& =0,0000778 \mathrm{~A}
\end{aligned}
$$$$
\mathrm{I}_{\mathrm{R} 3}: \mathrm{I}_{2}=\frac{R 2}{R 2+R 3} \text { I total }
$$

$$
\begin{aligned}
& =\frac{100 K \Omega}{1500 K \Omega+100 K \Omega} 0,000083 \\
& =0,0000055 \mathrm{~A}
\end{aligned}
$$




\section{KESIMPULAN DAN SARAN}

Pada eksperimen ini telah dipelajari hukum kirchoff I dan hukum kirchoff II, baik dirangkai sebagai rangkaian seri, parallel dan seri-paralel(gabungan). Hasil eksperimen dengan hasil teori dapat dilihat sebagai berikut (Tabel 9.2):

Tabel 9.2 Hasil 1 eksperimen penyearah gelombang

\begin{tabular}{llll}
\hline Keterangan & Rangkaian Seri & Rangkaian Paralel & Rangkaian Seri Paralel \\
\hline $\begin{array}{l}\text { Hasil } \\
\text { eksperimen }\end{array}$ & $\begin{array}{l}\text { Tegangan sumber }= \\
\text { Hasil teori }\end{array}$ & $\begin{array}{l}\text { Tegangan sumber }= \\
12 \mathrm{~V}\end{array}$ & Tegangan sumber $=12$ \\
& $\mathrm{~V} 1=0,37 \mathrm{~V}$ & $\mathrm{~V} 1=12 \mathrm{~V}$ & \\
& $\mathrm{~V} 2=0,73 \mathrm{~V}$ & $\mathrm{~V} 2=12 \mathrm{~V}$ & Vseri $=4,23 \mathrm{~V}$ \\
& $\mathrm{~V} 3=10,95 \mathrm{~V}$ & $\mathrm{~V} 3=12 \mathrm{~V}$ & Total $=12,01 \mathrm{~V}$ \\
& Total $=12,05 \mathrm{~V}$ & & \\
\hline
\end{tabular}

\section{Referensi}

[1] Halliday, D., Resnick, R., Walker, Fundamenthal of Physics-Extended, $5^{\text {th }}$, John Wiley \& Sons, New York 1997.

[2] Putra, V.G.V,, Endah dan Ngadiono, Pengantar Listrik Magnet dan Terapannya, Penerbit CV. Mulia Jaya, Yogyakarta, 2016.

[3] Suarga, Fisika Komputasi Solusi Problema Fisika dengan Matlab, Penerbit Andi, Yogyakarta, 2005.

[4] Jumadi, Praktikum Analisis Rangkaian Listrik, 2010 


\section{BIOGRAFI PENULIS}

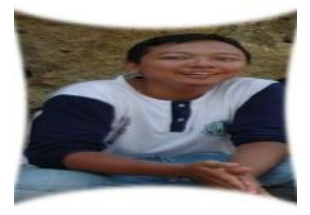

Dr.Valentinus Galih V.P., M.Sc.S.Si lahir di desa

Wedi, Kabupaten Klaten, Jawa Tengah pada tanggal 4 Maret 1987. Pendidikan dasar sampai menengah diselesaikan di kota kecil Bekasi, Jawa Barat.

Penulis menamatkan pendidikan starta satu (S-1), Master (S-2) dan Doktor (S-3) Fisika di Fakultas Matematika dan Ilmu Pengetahuan Alam FMIPA UGM. Saat ini penulis adalah seorang pengajar aktif di D-4 dan S-2 Politeknik STTT Bandung.

Kegiatan Organisasi dan Riwayat pekerjaan penulis:

1. Asisten Tugas Lab I, II dan III di Laboratorium Fisika UGM (2007-2009).

2. Tim panitia Lomba Fisika Nasional (TOP COP UGM), UGM, Yogyakarta( 2007).

3. Tim Koordinator Lomba cerdas cermat KKN-PPM UGM, Yogyakarta di Purworejo (2008).

4. Anggota keluarga mahasiswa Katolik (KMKath), UGM, Yogyakarta (2005-2010).

5. Pengajar Fisika dan Matematika SMA, LBB SSC, Yogyakarta (20102012).

6. Pengajar Olimpiade Sains Nasional Fisika SMA De Britto,Yogyakarta dan SMP IPH School, Surabaya (2011-2013).

7. Asisten dosen Mata Kuliah Fisika Matematika, Prodi Geofisika, Jurusan Fisika UGM, Yogyakarta (2012).

8. Dosen Fakultas Teknik Informatika Universitas Dian Nuswantoro, Semarang, Mata kuliah: Fisika dasar I dan 2, Pengantar Elektronika Dasar, (2012-2013).

9. Dosen Fisika D4 dan S-2, Politeknik STTT, Bandung, Mata Kuliah: Utilitas I, Otomasi, Mekatronika Tekstil, Praktikum Mekatronika Tekstil, Praktikum Fisika Dasar I dan 2, Rekayasa Tekstil dan Apparel, Elektronika Tekstil (2014-sekarang). 


\section{BIOGRAFI PENULIS}

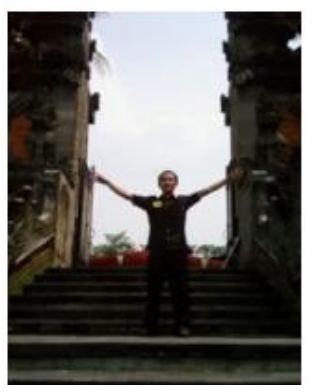

Ngadiyono, ST. dilahirkan di kota Semarang, Jawa Tengah pada tanggal 2 Maret 1986. Pendidikan dasar sampai dengan diploma III diselesaikan di kota Semarang. Penulis menamatkan pendidikan diploma III Teknik Elektro (DIII) di Politeknik Negeri Semarang dan (S-1) Teknik Elektro di Sekolah Tinggi Teknologi Mandala di Bandung Jawa Barat,.

dan sambil bekerja sebagai Pranata Laboratorium Pendidikan dan dosen di Politeknik STT Tekstil Bandung

Riwayat Pekerjaan

1. Dosen di Politeknik STTT, Bandung, Mata Kuliah: Praktikum Fisika Dasar I dan 2 (2011-2013)., Praktikum Perajutan I dan II (2012sekarang), Praktikum Mekatronika Teksti (2016-sekarang)

2. Pranata Laboratorium Pendidikan, Politeknik STTT, Bandung (2011sekarang)

Karya Ilmiah

1. Modul Praktikum Perajutan II, Politeknik STTT, Bandung, 2014

2. Pengantar Listrik Magnet dan Terapannya, CV Mulia Jaya, Yogyakarta, 2016 


\section{BIOGRAFI PENULIS}

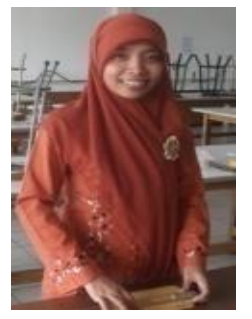

Endah Purnomosari, ST. dilahirkan di kota kecil Cepu, Kabupaten Blora, Jawa Tengah pada tanggal 30 Desember 1984. Pendidikan SD sampai SMP diselesaikan di kota asalnya. Kemudian melanjutkan pendidikan SMK Telkom di kota Purwokerto, Jawa Tengah. Penulis menamatkan pendidikan diploma III Teknik Elektro (DIII) di Politeknik Negeri Semarang,

Jawa Tengah dan (S-1) Teknik Elektro di Sekolah Tinggi Teknologi Mandala di Bandung, Jawa Barat sambil bekerja sebagai Pranata Laboratorium Pendidikan dan dosen Fisika di Laboratorium Fisika Dasar di Politeknik STT Tekstil Bandung.

Kegiatan Ilmiah yang pernah diikuti:

1. Indonesian Textile Conference, Seminar Nasional Tekstil 2014

2. Seminar Nasional SPIRIT 2015 Kementerian Perindustrian 2015

Riwayat Pekerjaan

1. Dosen Fisika, Politeknik STTT, Bandung, Mata Kuliah: Praktikum Fisika Dasar I dan 2 (2010-sekarang).

2. Pranata Laboratorium Pendidikan, Politeknik STTT, Bandung (2010-sekarang)

\section{Karya Ilmiah}

1. Pengantar Eksperimen Fisika ( untuk SMA/ S-1), CV Mulia Jaya, Yogyakarta, 2015

2. Pengantar Listrik Magnet dan Terapannya, CV Mulia Jaya, Yogyakarta, 2016 